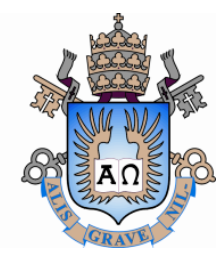

Kárida Mateus de Souza

\title{
As EMSPs e o Campo Geral da Discursividade Humanitária
}

Dissertação apresentada como requisito parcial para obtenção do grau de Mestre pelo Programa de Pós-graduação em Relações Internacionais do Instituto de Relações Internacionais da PUC-Rio.

Orientadora: Profa. Monica Herz

Rio de Janeiro Outubro de 2014 
Kárida Mateus de Souza

\section{As EMSPs e o Campo Geral da Discursividade Humanitária}

Dissertação apresentada como requisito parcial para obtenção do grau de Mestre pelo Programa de Pós-graduação em Relações Internacionais do Instituto de Relações Internacionais da PUC-Rio. Aprovada pela comissão examinadora abaixo assinada.

Profa. Monica Herz

Orientadora e Presidente Instituto de Relações Internacionais - PUC-Rio

Profa. Marta Regina Fernández y Garcia Moreno Instituto de Relações Internacionais - PUC-Rio

Prof. Reginaldo Mattar Nasser Pontifícia Universidade Católica de São Paulo - PUC-SP

Prof. Monica Herz

Vice-Decana de Pós-Graduação do Centro de Ciências Sociais - PUC-Rio

Rio de Janeiro, 06 de Outubro de 2014. 
Todos os direitos reservados. É proibida a reprodução total ou parcial do trabalho sem a autorização da universidade, do autor e do orientador.

\section{Kárida Mateus de Souza}

Graduou-se em Relações Internacionais pela Pontifícia Universidade Católica do Rio de Janeiro (PUC-Rio) em 2011, onde fez parte de grupos de pesquisas acadêmicas tais como o PIBIC, TEPP e HASOW. Estudou temas multidisciplinares na Peking University, China, em 2011 e foi Visiting Fellow Researcher na Brown University, EUA, em 2013. Atualmente desenvolve pesquisa no âmbito da Política Internacional sobre temas que atravessam o humanitarismo e a segurança internacional.

Ficha Catalográfica

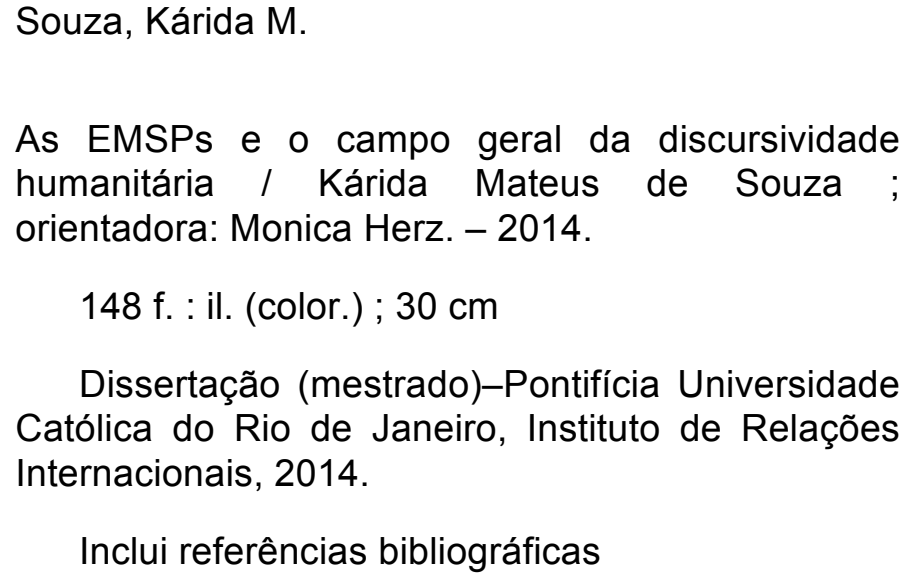

1. Relações Internacionais - Teses. 2. Empresas Militares ou de Segurança Privada. 3. Novos Humanitários. 4. Significante Vazio. 5. Ação Humanitária. 6. Segurança Humana. 7. Proteção. I. Herz, Monica. II. Pontifícia Universidade Católica do Rio de Janeiro. Instituto de Relações Internacionais. III. Título. 
Ao interlocutor. 


\section{Agradecimentos}

À mamãe pela inabalável esperança e positividade, suportes imprecindíveis para uma estudante de Política Internacional.

À orientadora Monica Herz por sua precisão, leveza e confiança neste trabalho.

Ao CNPq cujo auxílio foi fundamental para a realização desta dissertação.

Às amigas Mariana Moreira, Jéssica Máximo, Sara Garay, Tina Lucente, Vanessa Zanella e Tayla Antunes pelo companheirismo, paciência, pelas conversas engraçadas, profundas e abstratas.

Ao Prof. Philipe Bonditti cuja crítica e dedicação nos atendimentos dariam forma ao projeto que precedeu esta dissertação.

À Profa. Anna Leander por ter me presenteado com o tema do militarismo privado em um de seus seminários.

Ao Prof. Naeem Inayatullah e à Sorayya Khan pela atenciosidade e amizade.

Ao Watson Institute for International Studies e à Brown University pela estupenda estrutura que me foi oferecida durante o desenvolvimento da pesquisa.

Ao Diogo Dario e Carlos Frederico Gama pelas opiniões a respeito desta dissertação.

Aos professores que aceitaram gentilmente o convite para serem parte da banca examinadora, a saber, Marta Moreno, Reginaldo Nasser e Roberto Yamato.

A todos os professores e funcionários do IRI e da PUC-Rio pelos ensinamentos e serviços prestados.

Ao Spotify cujas trilhas foram muito importantes para terminar os capítulos. 


\section{Resumo}

Souza, Kárida Mateus de; Herz, Monica. As EMSPs e o Campo Geral da Discursividade Humanitária. Rio de Janeiro, 2014. 148p. Dissertação de Mestrado - Instituto de Relações Internacionais - Pontifícia Universidade Católica do Rio de Janeiro.

As mudanças contextuais no curso histórico das práticas emergenciais e as possibilidades discursivas delas emergentes têm permitido a diversificação dos atores e do modo com que é feita a entrega da ajuda humanitária. As noções de neutralidade, humanidade e proteção que permeiam o humanitarismo são manejadas de acordo com distintos princípios e interesses. Ao longo do século $\mathrm{XX}$ e adiante, o conjunto de significantes que se referia à prática da assistência humanitária deu oportunidade para que novos discursos fossem capazes de criar outras articulações para o que se compreende como "humanitário" ou "ação humanitária". O progressivo agenciamento das Empresas Militares ou de Segurança Privada (EMSPs) neste campo é parte desse fenômeno e desafia o espaço que, na concepção das agências humanitárias tradicionais, se supunha desmilitarizado. A dissertação analisa como se deu o processo discursivo de abertura às EMSPs e como a emergência do "novo humanitarismo" contribuiu para o cenário de disputas políticas que visam legitimar uma determinada cadeia discursiva em detrimento de outras narrativas no que se propõe como campo geral da discursividade humanitária.

\section{Palavras-chave}

Empresas militares ou de segurança privada; novos humanitários; significante vazio; ação humanitária; segurança humana; proteção. 


\section{Abstract}

Souza, Kárida Mateus de; Herz, Monica (Advisor). The PMSCs and the General Field of Humanitarian Discursivity. Rio de Janeiro, 2014. 148p. M.A Dissertation - Instituto de Relações Internacionais - Pontifícia Universidade Católica do Rio de Janeiro.

The contextual changes in the historical course of the practices of emergency and the discursive possibilities resulting from that, have yielded the diversification of actors and the way in which the humanitarian aid is delivered. The notions of neutrality, humanity and protection that pervade the humanitarianism are managed in accordance to different principles and interests. Throughout the twentieth century and on, the set of signifiers referring to the practice of humanitarian assistance have opened up the opportunity for new discourses to be creating other articulations to what is understood as "humanitarian" or "humanitarian action". The progressive agency of Private Military or Security Companies (PMSCs) in this field is part of that phenomenon and defies the space that, according to the traditional humanitarian agencies, was supposed to be demilitarized. The dissertation examines how the discursive process of openness to PMSCs have taken place and how the emergence of the "new humanitarianism" contributed to the scenario of political disputes that seek to legitimize a particular discursive chain rather than other narratives within what I propose as the general field of humanitarian discursivity.

\section{Keywords}

Private military or security companies; new humanitarians; empty signifier; humanitarian action; human security; protection. 


\section{Sumário}

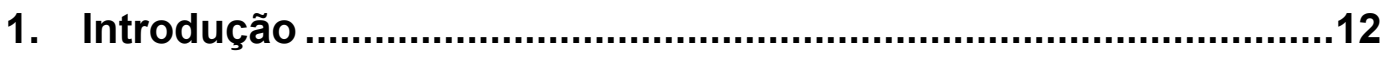

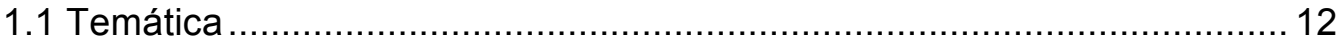

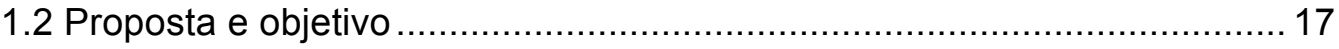

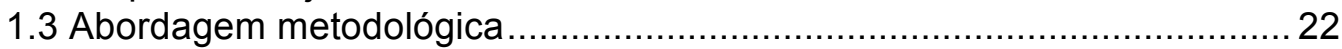

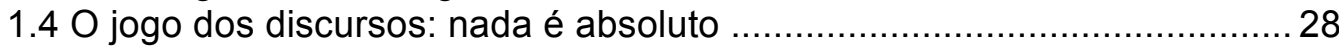

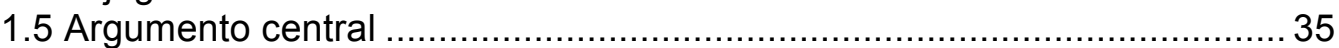

1.6 As narrativas marginais do campo humanitário ..................................... 36

1.7 As articulações discursivas que atravessam o campo humanitário .......... 41

2. A expansão do humanitarismo moderno e de seus agentes........53

2.1 Compreensão histórica da prática humanitária ...................................... 53

2.2 A política da interpretação: humanitarismo, desenvolvimento e

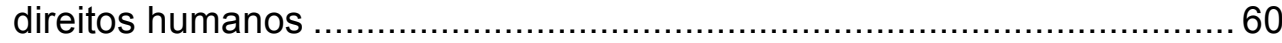

2.3 A interpretação das políticas: humanitarismo enquanto um nome ............66 66

3. As EMSPs e sua agência ..........................................................80

3.1 Compreensão histórica da prática militar privada ................................... 80

3.2 As EMSPs modernas e suas condições de existência ............................ 87

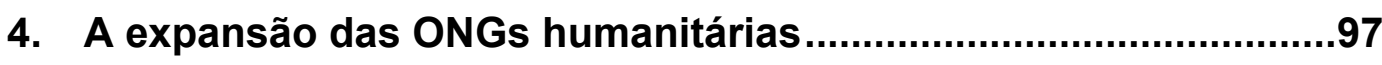

$4.1 \mathrm{O}$ encontro de discursos expansivos .................................................... 97

4.1 A segurança humana como ponto nodal ............................................ 103

5. Mesclando forças ..................................................................117

5.1 As oportunidades para as EMSPs..................................................... 117

5.2 Discursos meta-orientados: proteção, prevenção e multidimensionalidade humanitária .................................................... 120

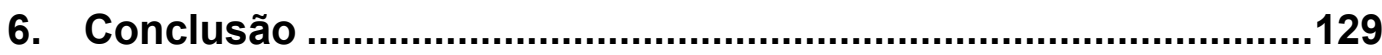

6.1 O significante vazio do humanitarismo ................................................ 129

7. Referências Bibliográficas......................................................138 


\section{Lista de Figuras}

Figura 01: Possibilidade discursiva num campo de duas lógicas equivalenciais. .48

Figura 02: Expansão do discurso da neutralidade.................................57

Figura 03: Três posições de sujeito no campo geral da

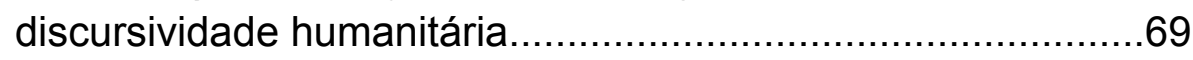

Figura 04: Vocabulário da proteção......................................................93

Figura 05: O campo geral da discursividade humanitária........................134

Tabela 01: Atividades das EMSPs.................................................122 


\section{Abreviaturas e siglas}

ACNUR - Alto Comissariado das Nações Unidas para Refugiados

AEND - Artefatos explosivos não detonados

AFRICOM - United States Africa Command

ANA - Afghan National Army

ANP - Afghan National Police

ANSI/ASIS PSC - American National Standards Institute for quality of Private Security Company operations

BRICS - Brasil, Rússia, Índia, China, África do Sul

CARE - Cooperative for Assistance and Relief Everywhere

$\mathrm{CDH}$ - Comissão de Direitos Humanos

CHS - Comission on Human Rights

$\mathrm{CIA}$ - Central Intelligence Agency

CICV - Comitê Internacional da Cruz Vermelha

COIN - Counterinsurgency/Contrainsurgência

DAC - Development Assistance Committee

DDR - Desmobilização, Desarmamento e Reabilitação

DIH - Direito Internacional Humanitário

EMPs - Empresas Militares Privadas

EMSPs - Empresas Militares e/ou de Segurança Privada

ESPs - Empresas de Segurança Privada

HDR - Human Development Report

HPG - Humanitarian Policy Group

$\mathrm{ICI}$ - International Charter Incorporated of Oregon

ICISS - International Commission on Intervention and State Sovereignty

ICoC - International Code of Conduct for Private Security Service Providers

ICSS - Comissão Internacional sobre Intervenção e Soberania Estatal

IDPs - Internal Displaced Persons

IPOA - International Peace Operations Association

ISAF/OTAN - International Security Assistance Force/ North Atlantic Treaty Organization 
ISOA - International Stability Operations Association

KLA - Kosovo Liberation Army

MPRI - Military Professional Resources Inc.

MSF - Médecins Sans Frontières

NAE - Neutralização de Artefatos Explosivos

NGOs - Non-Governmental Organizations

ODI - Overseas Development Institute

OECD - Organization for Economic Co-operation and Development

ONGs - Organizações Não-Governamentais

ONU - Organização das Nações Unidas

OTAN - Organização do Tratado do Atlântico Norte

PMC - Private Military Company

PNUD - Programa das Nações Unidas para o Desenvolvimento

PSCs - Private Security Companies

PSMCs - Private Military and Security Companies

R2P - The Responsibility to Protect

SSR - Security Sector Reform

UN - United Nations

UNDP - United Nations Development Programme

UNOPS - United Nations Office for Project Services

USAID - United States Agency for International Development

WASH - Water, Sanitation and Hygiene 


\section{Introdução}

\subsection{Temática}

Há alguns anos, verifica-se o crescimento de pesquisas que se preocupam em estudar as extensões do sistema de ajuda humanitária às esferas militar e privada. Alguns autores, por exemplo, Rita Abrahamsen \& Michael Williams (2006) Deborah Avant (2000), Anna Leander (2005), etc., perguntam-se quais eventos ou condições favoreceram a chegada das empresas militares ou de segurança privada (EMSPs) ${ }^{1}$, outros, como Christopher Spearin (2008), Jutta Joachim \& Andrea Schneiker (2012), Peter Singer (2001), etc., se concentram na relação que fora criada entre estas empresas e as atividades humanitárias nas últimas décadas. Geralmente, as oportunidades de mercado - como por exemplo, a demanda por EMSPs decorrente do aumento dos conflitos de baixa intensidade (Dunning, 2010) - e as oportunidades políticas, por exemplo, o lobby em favor das contratações surgidas durante as invasões do Afeganistão em 2001 e do Iraque em 2003 (Isenberg, 2012), são citadas como cruciais para que os militares privados, também chamados de mercenários, estabelecessem sua presença nos espaços de emergência. Chega-se a encontrar, adicionalmente, o argumento de que a indisposição dos próprios humanitários em recorrer a métodos alternativos de segurança para fornecer ajuda e assistência em ambientes considerados inseguros também teria contribuído para o crescimento das EMSPs (Guidero, 2012). Existe, portanto, um momento em que as emergências humanitárias, ainda que em ambientes muito violentos, não conheciam as atividades mercenárias senão como partes combatentes, e um outro momento, quando as EMSPs foram criadas e passaram a formar parte do grupo de atores não necessariamente combatentes no campo. Esta passagem ocorreu ao fim da Guerra Fria e a presente pesquisa considera que os argumentos de autores como os acima mencionados são relevantes para compreender estas mudanças que atravessam os espaços de

\footnotetext{
${ }^{1}$ A nomeclarura EMSPs refere-se às empresas como militares "ou" de segurança privada devido a dificuldade encontrada por muitos analistas em separar as empresas claramente entre ambas categorias.

${ }^{2}$ Por discurso histórico me refiro à regulação do Direito Internacional Humanitário, a criação do Comitê Internacional da Cruz vermelha, a ratificação das convenções de Genebra pelos Estados, as citações das práticas caritativas em ambientes de conflito como questões humanitárias, a
} 
emergência humanitária; entretato, aqui busca-se adicionar às análises sobre a temática a questão de como certas narrativas são capazes de criar inúmeras possibilidades de articulação e reinterpretação do que se designa como assistência humanitária, um fenômeno diretamente ligado ao processo de agenciamento das EMSPs.

Explora-se como, ao longo do século $\mathrm{XX}$, as noções de proteção, legitimação e neutralidade foram (re)articuladas e expandidas de modo a ser possível o surgimento de novas práticas e atores nessa esfera. Um dos focos está no discurso histórico ${ }^{2}$ que legitima a presença dos humanitários em situações de emergência e, também, nos discursos que, semelhantemente, possam vir a legitimar a atuação dos chamados soldados privados considerados por vários acadêmicos como parte de uma nova e importante evolução da política e da provisão da segurança (Abrahamsen \& Williams, 2007, p. 34) e os mais novos e contraditórios atores "humanitários" do campo (Berndtsson, 2012; Swisspeace, 2007).

A questão aqui levantada emerge a partir da compreensão de que, ao fim da Guerra Fria, o humanitarismo parece assumir um caráter cada vez mais diferenciado à medida que vários atores lutam por um alargamento do sistema de ajuda humanitária. O pano de fundo desta mudança são situações desafiadoras com as quais se deparavam os atores humanitários, tais como desastres naturais e conflitos civis, que provocavam grandes deslocamentos internos de pessoas e refugiados. O caráter de tais fenômenos e o modo com o qual governos, instituições internacionais e as agências da ONU lidavam com os mesmos viriam a ser conhecidos como "emergência complexa" (Duffield, 2001; Fox, 2002), um dos objetos de discussão do capítulo 2.

A partir da década de 1990, notou-se que uma série de vocabulários tornavam-se comuns entre diferentes instituições, organizações governamentais e não governamentais. Mas o uso de um vocabulário semelhante entre as agências humanitárias e as EMSPs no que tange à proteção e à entrega de alívio levou a um receio de que a atuação destas últimas, num espaço que se supunha

\footnotetext{
${ }^{2}$ Por discurso histórico me refiro à regulação do Direito Internacional Humanitário, a criação do Comitê Internacional da Cruz vermelha, a ratificação das convenções de Genebra pelos Estados, as citações das práticas caritativas em ambientes de conflito como questões humanitárias, a apropriação do vocabulário da "ação humanitária" em espaços de emergência e seu uso acadêmico e midiático, e o desenvolvimento destas narrativas por meio de articulações que se referem de modo geral a uma "história do humanitarismo".
} 
desmilitarizado, incorresse em implicações políticas negativas para os humanitários, uma vez que a imagem de militares terceirizados como 'mercenários' e 'cães de guerra' pouco se adequava ao discurso do ideal humanitário tradicional. Chegou-se a temer que a abertura da indústria às EMSPs pudesse, potencialmente, gerar uma futura aglutinação identitária entre militares privados e humanitários (Brekalo, 2012). Entretanto, considerar uma fusão tão homogênea entre estas instituições seria demasiado mediante as narrativas disponíveis no momento, muito embora a Teoria do Discurso jamais descarte algo como impossível no que tange as práticas institucionais (Laclau \& Mouffe, 1987).

A escolha da Teoria do Discurso na pespectiva de Laclau \& Mouffe (1987) como marco teórico nesta dissertação se deu pela capacidade explicativa no que tange a relação entre as narrativas e a formação da realidade social. Faz-se uma análise dos movimentos discursivos, i.e., da forma e do conteúdo dos signos, que se assemelha um pouco à formação geométrica dos conjuntos, uma analogia válida para se compreender heuristicamente o fortalecimento de certas cadeias discursivas ou a perda de um status privilegiado de determinado discurso no tempo. A possibilidade de categorizar os discursos por meio do estudo dos significantes e significados permite o entendimento de fenômenos que em outras perspectivas seriam considerados de modo causal ou naturalmente tomados como contraditórios por si mesmos.

Como observa Mendonça (2012), os teóricos Laclau \& Mouffe (1985) apresentam um complexo de categorias analíticas que possui um sentido específico. O discurso não é tão somente formado por características linguísticas que se restringem aos atos de fala ou ao que está estritamente escrito. Ademais, esta abordagem é uma teoria política, uma vez que o político tem espaço privilegiado na análise da formação das cadeias discursivas. O político para Laclau \& Mouffe (1985) constitui-se a partir de relações de poder medidas antagonicamente, o que significa dizer que, "se o social deve ser compreendido a partir de lógicas discursivas, essas lógicas devem ser analisadas a partir da ideia de discursos em luta, de discursos antagônicos" (Mendonça, 2012, p. 207). Nessa abordagem, portanto, aquilo que é "discursivo" pode ser tanto fala e escrita quanto imagem e ação. 
Nesse sentido, se o discurso possui a sua evidente dimensão linguística, ele também carrega em si outra, ou seja, a dimensão extralinguística. $\mathrm{O}$ discurso, assim, deve ser entendido a partir da admissão de que toda prática social é uma prática significativa, pois que o social em si é um social significativo. Portanto, discurso possui uma dimensão ontológica (Mendonça, 2012, p. 206).

A concepção do discurso em sua dimensão ontológica, deste modo, enfatiza o caráter constitutivo da linguagem, posicionando a teoria do discurso como parte da virada linguística nas ciências sociais. A importância dessa concepção da linguagem para os fins desta pesquisa é desenvolvida na seção "Abordagem metodológica".

O presente trabalho considera que as narrativas influenciam na formação de novos atores e suas práticas no campo do humanitarismo. A associação ou imiscuição das EMSPs no campo humanitário levanta, portanto, questões de como é possível o elo entre duas atividades antes vistas como incompatíveis em termos de princípios, uma vez que ambas as posições estiveram historicamente em esferas diferentes de atuação. Existe, então, um problema de pesquisa que se desenvolve a partir do estranhamento da abertura do humanitarismo a novos atores e princípios no século XX. A compreensão desta abertura inicia-se por meio do estudo das práticas e narrativas relacionadas diretamente aos humanitários. Busco, desta forma, identificar os fenômenos discursivos mais relevantes para compreensão dos precedentes da constituição de novos atores e novas capacidades de atuação no campo humanitário, como se verá ao longo dos capítulos.

Embora o problema de pesquisa seja amplo e abra potencialmente espaço para futuros desenvolvimentos, o foco principal se concentrará no período a partir do fim da Guerra Fria, quando houve uma explosão no número das atividades das EMSPs ao redor do globo (Dunning, 2010; Avant, 2007a)

No que tange à influência das narrativas e interpretações de um conceito, a dissertação se preocupa com a relação criativa entre discurso e prática, de modo que até mesmo a noção de contradição se perde em meio a uma demanda política. Isto é, enquanto que a atividade humanitária das EMSPs pode ser vista como contraditória por ter fins lucrativos, argumentos em seu favor podem tornar essa contradição uma demanda política naturalizada pelo cada vez mais complexo ambiente da atividade humanitária. 
Certamente que a multiplicidade de definições de um conceito, como "humanitarismo" ou "ajuda humanitária", por si só pouco poderia contribuir para explicar a relação entre militares privados e humanitários; contudo, percebe-se que a criação de relações entre sujeitos, instituições e organizações sem afinidade histórica raramente se constituiria sobre bases conceituais fechadas, sobre conceitos pétreos; assim, a premissa mais básica desta dissertação é a de que o humanitarismo enquanto discurso é uma narrativa aberta. Desde modo, a emergência de uma articulação discursiva que trate, por exemplo, a existência de um "soldado humanitário" como uma posição de sujeito imprescindível em determinados espaços de emergência é um discurso que só será ‘absurdo' ou 'não absurdo’ a partir dos critérios políticos de análise.

Como será desenvolvido no capítulo 2 , enquanto que as críticas sobre a presença das EMSPs em campos humanitários é pertinente para aqueles que usam o critério dos princípios que teoricamente regeram o trabalho humanitário (a neutralidade, imparcialidade e independência), a mesma pertinência vale para os argumentos das ONGs e de setores de defesa e segurança que usam o critério da necessidade de eficiência, da prevenção de insurgências ou da "segurança humana" para definir as justificativas contratuais no campo humanitário. Entretanto, nem sempre as justificativas são diretamente proporcionais às demandas daqueles cujos espaços são acampados: os receptores, i.e., as chamadas vítimas da situação de emergência. Da parte da população local, parece haver uma assimetria quanto ao poder de agência e à securitização de diferentes aspectos de suas vidas. Estas demandas que se manifestam como discursos são analisadas mais adiante neste capítulo.

As diversas posições políticas que existem atualmente no sistema de ajuda humanitária são, portanto, demandas que formam forças sociais, ou melhor, forças políticas que podem ou não encontrar partido em outros setores institucionais $\mathrm{e}$ com eles entrar em "equivalência". No capítulo 2, será abordada a noção da lógica de equivalência, um conceito desenvolvido por Ernesto Laclau (2005) que tem grande importância teórica no que diz respeito a quais discursos são privilegiados e quais discursos são deixados marginalmente nas cadeias discursivas que permeiam o humanitarismo. A “cadeia de equivalência é, posto simplesmente, um processo em que a similaridade das entidades as conecta de modo a criar identidades ou outras entidades", isto é, um processo que investe 
significado a um significante chave (Jørgensen \& Phillips, 2002), neste caso, o significante "humanitário".

A dissertação vai abordar sobre os modos de formação dos discursos que se alocam num ambiente social de modo antagônico ou equivalente. As entidades humanitárias tradicionais, por exemplo, veem a figura do militar privado como inadequado aos princípios e à história de seu movimento, já as entidades humanitárias não tradicionais (doravante, "novos humanitários"), por outro lado, tendem a descrevê-lo de maneira mais pragmática, por sua adequação técnica; menos pelo nome que carrega e mais pelas atividades que empreende, ainda que tais coisas não estejam de todo separadas.

Estas e outras possibilidades de articulação do fenômeno não surgem, no entanto, sem implicações políticas e jurídicas para as situações de emergência, como se verá no capítulo 4 onde as oportunidades para as EMSPs implicam na restrição de uma série de direitos.

\subsection{Proposta e objetivo}

O tema desta dissertação é consoante com o interesse nas pesquisas que lidam com o tema do militarismo privado no pós-Guerra Fria, fenômeno que coincide com o discurso neoliberal da necessidade de expertise privado com a criação das primeiras firmas de segurança privada (cf. Brekalo, 2012) fornecendo serviços de distintas naturezas. Além disso, também faz parte do momento de maior interesse sobre como a atividade de empreiteiros armados viria entrar no campo do humanitarismo. No entanto, as pesquisas que tinham por objetivo tratar das intercessões entre estes dois campos vieram a ganhar um foco significativo somente a partir dos anos 2000.

Com o aumento da indústria militar privada principalmente pelos crescentes contratos com o governo dos EUA, muitos pesquisadores voltaram seus olhares para a possibilidade de mudanças que poderiam se desencadear com a constante especialização da força privada ou, como preferem alguns, a especialização da prática mercenária no mundo contemporâneo (cf. Cockayne, 2009). Enquanto que alguns autores viriam ser referências comuns para chamar atenção para o fenômeno em situações de guerra e no campo da ajuda humanitária (Singer, 2001; Avant, 2000; Spearin, 2008; Leander, 2005, etc.), outros, viriam a utilizar a mídia 
como ferramenta de difusão e diálogo, por exemplo, na área do jornalismo investigativo (David Scahill 2007, 2013; David Isenberg, 2009). As abordagens sobre questões legais, éticas ou mercadológicas que envolvem a atuação das EMSPs ainda não se esgotaram e, na verdade, continuam a crescer exponencialmente com as dinâmicas globais no tema da segurança e da governança; no entanto, o conjunto de trabalhos publicados, em grande parte, não se afasta muito destas três chaves de análise.

No caso desta pesquisa, há uma tentativa de transcender estas análises no sentido de trazer à luz uma perspectiva teórica distinta. A sugestão é que voltemos nosso olhar para as mudanças na ajuda humanitária de uma forma mais ampla. Existe a necessidade de observarmos de modo estrutural como se formam as cadeias de discursos emergindo do campo social da ajuda humanitária e, para isso, a pesquisa vai buscar os processos de formação de antagonismos e oposições reais ${ }^{3}$ (Laclau \& Mouffe, 1987) desse campo que é chamado "humanitário".

Os antagonismos se constituem quando as identidades e as alteridades são construídas a partir de uma relação de negatividade, não possuindo, portanto, uma dimensão positiva em si mesmas. Pois; para Laclau \& Mouffe (1987) as

\footnotetext{
${ }^{3}$ Embora o conceito de "oposições reais" não vá ser trabalhado nesta dissertação, vale ressaltar sua diferença em relação aos processos antagônicos. Enquanto que o antagonismo é um processo necessariamente político, ele também é necessariamente discursivo e não necessariamente material. A formação discursiva que promove a constituição de uma identidade, por exemplo, não é uma relação material ou objetiva que precede a relação, é um trabalho subjetivo. O mesmo não ocorre com as oposições reais, que pressupõem a pré-existência objetiva de dois elementos que vão entrar em oposição. Mendonça (2012) faz uma boa síntese do significado deste conceito e também do conceito de "contradição lógica" nas leituras de Laclau \& Mouffe $(1985 ; 1987)$, que são insights relevantes para os momentos em que esta dissertação se referir aos elementos materiais e simbólicos que diferenciam humanitários tradicionais, novos humanitários e as EMSPs. A síntese de Mendonça (2012) é a seguinte:

“(...) Segundo a leitura de Laclau \& Mouffe (1985), 'oposição real' indica que 'A - B' são termos diferentes cujas positividades existem independentemente da relação que porventura eles possam ter entre si. A 'oposição real' ocorre no terreno dos objetos reais (real objects). Como exemplo, os autores apresentam uma hipotética batida entre dois veículos e afirmam: "(....) [É] claro que um antagonismo não pode ser uma oposição real. Não há nada antagônico numa batida entre dois veículos: este é um fato material que obedece a leis físicas objetivas" (1985, p. 123 apud Mendonça, 2012, p. 208). (...) “Já a ideia de 'contradição lógica' é representada pela fórmula 'A não A'. Segundo essa noção, a relação entre dois termos esgota a realidade de ambos. A 'contradição lógica' ocorre no terreno das proposições, dos conceitos. Contudo, contradição não redunda em antagonismo, pois "todos nós participamos de uma série de sistemas de crenças mutuamente contraditórios e nenhum antagonismo emerge destas contradições" (Laclau \& Mouffe, 1985, p. 124 apud Mendonça, 2012, p. 209). (...) "Laclau \& Mouffe, após apresentarem a diferença entre "oposição real" e "contradição lógica", passam a explicar o que tais categorias têm em comum e o que as faz, assim, completamente diferentes da noção de antagonismo. Nesse sentido, 'oposição real' e 'contradição lógica' "partilham algo, o fato de serem relações objetivas, entre objetos conceituais no segundo caso, e entre objetos reais no primeiro. Mas, em ambos os casos, isto é alguma coisa que os objetos já são, a qual faz a relação inteligível" (1985, p. 124, grifos do original). Em outras palavras, os autores afirmam que, seja num caso, seja no outro, se está diante de positividades, de objetos plenamente construídos, absolutamente prontos e inteligíveis. Assim, estamos falando de "relações objetivas", de "objetos já existentes", de "identidades completas" (Laclau \& Mouffe, 1985 apud Mendonça, 2012, p. 209).
} 
identidades não possuem uma existência que precede a relação antagônica, já que não existem positivamente ${ }^{4}$. Em vez de ser uma mera oposição entre objetividades já dadas, o antagonismo é justamente o momento em que estas identidades se constituem politicamente. Quando um grupo étnico é expulso de um território em nome da unidade nacional de um grupo dominante, por exemplo, essa minoria vai constituir sua nova identidade política pelo processo de negatividade, pelo ato de negação de sua constituição enquanto parte da unidade do grupo que os expulsou. Esse antagonismo denuncia, portanto, a falta de objetividade e essencialidade tanto do grupo dominante quanto da minoria que foi rejeitada.

No caso do humanitarismo, a proposta é de que os antagonismos ocorrem quando existe um fracasso mútuo na constituição das identidades dos grupos que alegam ser os legítimos agentes humanitários no campo. A relação de antagonismo entre os atores que trabalham com o discurso da ajuda humanitária conduzirá a um movimento de articulação de forças (sociais) que vai possibilitar as formações hegemônicas, uma vez que estas forças se organizam em função de pólos onde se debatem as diferenças e as identidades de modo antagonístico.

As fronteiras das formações antagônicas são produzidas pela fixação provisória de significados onde ocorrem tanto exclusões de certos discursos considerados ameaçadores a determinada demanda política, quanto assimilações por meio de equivalências, cooptações de grupos, etc. Como se verá mais adiante neste capítulo, o tecido grupal que mantém unida uma identidade humanitária passa por um processo contínuo de dissolução e reconstituição em virtude dos processos de deslocamento ${ }^{5}$ e (re)articulações de sentidos e demandas.

A dissertação também visa contribuir na arguição sobre os fundamentos teóricos da possibilidade de constituição de pelo menos duas novas realidades na indústria da ajuda humanitária que são adjacentes: por um lado, o acirramento da diferenciação entre humanitários tradicionais versus novos humanitários quanto à atuação baseada em princípios e, por outro, a formação de uma mudança epistêmica ocorrendo no humanitarismo advindo de uma luta hegemônica pelo

\footnotetext{
${ }^{4}$ A menos que sejam identidades completas como no caso das relações objetivas. Vide nota anterior.

${ }^{5} \mathrm{Na}$ perspectiva de Laclau, o "deslocamento" ocorre quando há situações de contestação de um discurso, o que o desestrutura internamente e cria uma crise de sentidos. Os elementos que mantinham este discurso mais coeso são afrouxados, o que denuncia sua contingência. $O$ deslocamento ocorre, portanto, na fronteira política interna do grupo (Laclau, 1986).
} 
seu significado. Este, no entanto, é o pano de fundo pelo qual as EMSPs formalizam sua agência no campo humanitário.

O objetivo da dissertação é, deste modo, analisar os discursos envolvidos no processo de agenciamento das Empresas Militares ou de Segurança Privada no campo humanitário e analisar, também, como certas narrativas trabalham para legitimar sua presença no campo. Isto leva, portanto, à pergunta central de pesquisa que questiona como tem se constituído a problemática do agenciamento de militares privados na área de ajuda humanitária.

De certo que, em termos do acesso à informação, sabe-se que as EMSPs não são empreendimentos públicos que têm o compromisso de liberar seus bancos de dados para pesquisa, mas o material disponibilizado por tais empresas em seus sites ou no site de suas associações - tais como relatórios, periódicos, revistas online, resumo de atividades no campo, etc. - foi considerado como uma das fontes primárias para a condução da pesquisa. $\mathrm{O}$ mesmo valeu para o acesso às divulgações das agências humanitárias. Tais materiais foram um meio pelo qual puderam ser identificadas as articulações e narrativas que privilegiam os discursos que relacionam a ação humanitária à segurança privada.

Entretanto, alguns desafios tiveram que ser enfrentados na pesquisa e outros só serão superados quando os projetos de transparência contratual entre EMSPs e governos saírem do papel, como ainda se discute no caso do congresso americano $^{6}$. Algumas ponderações devem ser feitas quanto à pluralidade de tarefas das EMSPs, uma vez que pode ser confuso tratar como empresas militares aquelas que só fazem segurança e logística, por exemplo. Para fins de delimitação de objeto, faz-se necessário qualificar que as EMSPs foco desta pesquisa são aquelas que, de modo direito ou indireto, fazem uso de narrativas sobre a ajuda humanitária e que podem ter contratos ou subcontratos firmados com agências humanitárias, organizações internacionais e governos, nem sempre com detalhes feitos conhecidos ao público.

\footnotetext{
${ }^{6}$ Em fevereiro de 2007, Barak Obama, ainda senador, introduziu a chamada "Lei de Transparência e Responsabilização na Contratação de Militares e Seguranças" (S. 674), uma emenda à Lei de Autorização de Defesa de 2008, exigindo que as agências federais informem o Congresso sobre o número de empreiteiros de segurança empregados, mortos e feridos e as ações disciplinares tomadas contra os mesmos. O projeto de lei foi encaminhado ao Comitê de Serviços Armados do Senado, mas nunca aprovado em lei. Já eleito presidente, a administração de Obama apresentou em Fevereiro de 2009 um conjunto de reformas destinadas a reduzir os gastos do Estado com prestadores privados de segurança militar, de inteligência e outros serviços considerados críticos e retornar certos trabalhos terceirizados de volta aos EUA como funcionários do governo em tempo integral (Isenberg, 2009).
} 
É relevante notar que a disponibilidade das publicações de grandes EMSPs cresce exponencialmente com seu anseio em angariar legitimidade do "grande público”. As empresas argumentam que o nível de transparência tem sido um dos elementos importantes para que seu trabalho seja reconhecido pela eficiência que lhes é requerida, deixando-se para trás a velha imagem que a prática mercenária tende a carregar ${ }^{7}$. Por parte das EMSPs envolvidas com ação humanitária, há um maior incentivo à publicação de portfólios para conquista de "corações e mentes" do que o contrário.

As EMSPs de maior renome no mercado são, em grande maioria, signatárias do $\mathrm{ICoC}^{8}$, o código internacional que regulamenta a conduta dos prestadores de serviços de segurança, e também associadas à ISOA, International Stability Operations Association", onde se encontram as EMSPs envolvidas em atividades não apenas de emergência humanitária, mas também em operações de estabilização, peacebuilding e contrainsurgência. O ISOA tem publicações regulares sobre os princípios, políticas e atuação dos membros no campo.

Por parte do discurso acadêmico, é relevante analisar as implicações e as contradições que a vinculação entre militarismo privado e ação humanitária possam produzir na política local e mundial. Se avaliarmos, por exemplo, o termo "soldado humanitário" ainda que seja raramente utilizado de modo direto, o engajamento entre EMSPs e humanitários não elimina a capacidade de articulação das práticas entre ambas as esferas no campo de atuação. Na verdade, a legitimidade destas empresas não depende de uma "aglutinação identitária", como o termo soldado humanitário poderia sugerir, mas da capacidade das EMSPs e de outros atores de estabelecerem sentidos de modo que sejam reconhecidos como indispensáveis para a manutenção de determinada política de ação.

\footnotetext{
${ }^{7}$ Existe neste caso uma evidente contradição entre os esforços por mais transparência por parte das EMSPs, como as publicações do ISOA, e a falta de transparência das mesmas no que tange a divulgação de números e nomes de parceiros em distintas missões. Até mesmo a ONU adere à pratica de "discrição". A UNOPS (United Nations Office for Project Services), por exemplo, não revela os fornecedores de serviços de segurança, "devido a razões de segurança", usando apenas especificações de serviços intencionalmente mínimas (Østensen, 2011, p. 55).

${ }^{8}$ Do inglês, International Code of Conduct for Private Security Service Providers.

${ }^{9}$ Antiga IPOA (International Peace Operations Association).
} 


\subsection{Abordagem metodológica}

A metodologia de pesquisa desta dissertação é a análise de discursos. A interpretação aplicada à analise dos distintos discursos se baseia na compreensão de que as identidades e os papéis atribuídos tanto à figura clássica do humanitário quanto à figura do soldado militar privado não têm fronteiras totalmente definidas. É o discurso mesmo que vai estabilizar tais categorias e isso é possível através da capacidade relativa dos discursos de apresentarem-se como coesos e naturais. Este processo de legitimação é facilitado pelos casos em que a construção da identidade não é considerada altamente instável internamente (Hansen, 2006, p. 26), ou seja, onde há uma coesão interna mínima haverá uma estabilidade da identidade de um grupo, regime ou instituição. A pesquisa, ao fazer uso da análise de discurso, vai tomar este processo discursivo como parte da formação da legitimidade interna dos grupos, o que de outro modo poderia se assemelhar a um "esforço genealógico", uma vez que busca identificar nos espaços de atuação do humanitarismo como certas coisas permanecem estáveis à medida que outras mudam ${ }^{10}$.

A análise do processo discursivo, sob uma ótica laclauniana, se dá no espaço social que esta pesquisa entende como campo humanitário onde se observa a mobilização de discursos em torno de muitas concepções que são importantes para este campo, como, por exemplo, os entendimentos sobre a neutralidade, segurança, legitimidade e humanidade. Isso requer que se tracem certos antecedentes conceituais bem como os movimentos de aproximação e afastamento de certos sentidos que em algum momento detiveram um "ancestral" comum. Este campo nada mais é que um espaço de articulações e interpelações discursivas que envolvem o tema do humanitarismo. Enquanto que muitos autores preferem utilizar a expressão "espaço humanitário", a dissertação compreende que a utilização exclusiva do termo pode se remeter a uma ideia de possibilidade de fechamento sem fraturas internas, como a proposta de um espaço apolítico (Warner, 1999) ou despolitizado (Barnett, 2005) poderia sugerir.

\footnotetext{
${ }^{10}$ Como observado por Milliken (1999, p. 246), espera-se que os trabalhos que visam construir genealogias nas Relações Internacionais procedam o estudo das relações entre pessoas e coisas como processos não totalmente fechados e que trabalhem condições de emergência que são heterogêneas e descontínuas.
} 
Embora não haja uma definição comum, a bibliografia convencional geralmente trabalha o espaço humanitário se referindo: ao ambiente operacional das agências humanitárias (Brassard-Boudreau \& Hubert, 2010), ao espaço de proteção e liberdade de relacionamento entre vítimas e humanitários (Terry, 2002), à capacidade das agências humanitárias de trabalhar de forma independente e imparcial, sem medo de ataque em busca do imperativo humanitário (Sida, 2005) ou ainda a um espaço físico e simbólico que as agências humanitárias precisam para poder operar segundo os princípios que defendem (Hilhorst \& Jansen, 2010).

A ideia de campo, por outro lado, permite que todas estas noções sejam trabalhadas como narrativas que expressam modos distintos de agenda e atuação que estão constantemente em disputa, como por exemplo, o entendimento da espacialidade da ajuda humanitária como uma oportunidade para formação de novas governanças, para implantação de políticas terapêuticas (Debrix, 1999) ou mesmo como um espaço exclusionário fora do globo (Esteves, 2010b). Isso expande o entendimento sobre outras lógicas que atravessam este campo, a partir do qual a noções convencionais de espaço humanitário retratam apenas uma parte do todo. Sua composição e extensão podem ser tanto territorializadas quanto desterritorializadas e serão mais bem detalhadas na próxima seção.

A abordagem metodológica está diretamente ligada à análise teórica, cuja perspectiva necessita indicar algumas diferenças linguísticas a respeito dos discursos que influenciam a formação das agências do campo da ajuda humanitária. Ao longo da pesquisa, faz-se a apresentação de conceitos como: ponto nodal, elementos, momentos, cadeia de equivalência, significante vazio e significante flutuante, etc., definidos a partir de Laclau \& Mouffe (1987). Estes conceitos são categorias que separam os discursos em graus de privilégio e fixidez, algo relevante para compreender como determinadas narrativas são tomadas como mais importantes do que outras na formação de uma identidade política, por exemplo. O processo de construção de conceitos comumente citados na área do humanitarismo (como neutralidade, humanidade e imparcialidade) e suas possíveis ressignificações ao longo do tempo, passam por estas categorias discursivas e são baseadas em uma característica importante de todos os discursos: a indeterminação. Sob esta abordagem teórico-metodológica, considera-se aqui que nenhum conceito tem suas fronteiras totalmente fechadas à 
interpelação; assim, quando observamos as narrativas do pós-Guerra Fria e os elementos parcialmente mantidos e parcialmente mudados nos discursos do humanitarismo podemos compreender por que as EMSPs são, por vezes, identificadas como humanitárias.

A análise mais ampla de como se constroem as formações discursivas vai, portanto, considerar fenômenos dos mais diversos como sistemas complexos de signos que podem fazer parte de uma mesma ordem institucional ou simbólica, um método que pode desestabilizar os entendimentos convencionais sobre a relação entre o regime de segurança e o sistema de ajuda humanitária na disciplina de Relações Internacionais.

Dentro da área de Relações Internacionais, a análise de discurso pode ser um recurso para se repensar a arbitrariedade da gênese das instituições e da origem de novos atores num determinado meio. A abordagem teóricometodológica aqui empreendida se contrasta, portanto, com a literatura mainstream que lidaria com o tema das EMSPs e do novo humanitarismo de modo semelhante ao que lida com os regimes e as instituições, isto é, geralmente privilegiando o desenho de uma racionalidade ou intencionalidade nas conformações sociais aos aspectos contingenciais e discursivos.

Diferentemente desse tipo de abordagem nas Relações Internacionais, o tema desta dissertação está diretamente relacionado à virada linguística advinda da filosofia, por meio da qual a análise de discurso viria ganhar centralidade uma vez que as regras, normas e símbolos viriam ser analisadas não apenas como instrumentos para a configuração dos eventos sociais e da ação política, mas como a própria ação política.

A partir de nosso tema, as escolas realista e neorrealista, por exemplo, não teriam lugar em seu quadro analítico para entendimentos sobre ressignificação de conceitos e variação institucional que não exclusivamente por desígnio, tanto porque privilegiariam o Estado na conformação das relações de poder entre militares privados e humanitários dando importância meramente marginal às instituições, quanto porque o realismo ontológico dessa abordagem é incompatível com as noções constitutivas da linguagem no que tange ao papel do discurso da conformação das agências no campo humanitário. Contudo, outras abordagens que se preocupam com a formação das agências num determinado campo social também merecem ser mencionadas. 
Embora o regime discursivo do humanitarismo seja aqui considerado como algo que transversaliza uma suposta separação entre agência e estrutura, vejamos outras concepções mais tradicionais com respeito à gênese dos atores e regimes na disciplina de (e nas) Relações Internacionais.

A vertente institucionalista neoliberal, por exemplo, concebe a estrutura normativa como importante para alterar os incentivos para a ação dos atores no campo sem alterar a estrutura material nela inseridas (cf. Keohane, 1984), mas autores preocupados com as chamadas "estruturas ideacionais" afirmariam que essa abordagem esquece de interpretar a dimensão normativa como parte constitutiva dessa "estrutura material". As premissas neoliberais só consideram a mudança das preferências e do comportamento dos atores, mas não das identidades. No que tange às abordagens mais normativas (ou reflexivistas) da disciplina, a estrutura normativa é entendida tanto como reguladora quanto constitutiva dos atores e também da estrutura social da qual fazem parte (ReusSmit, 1999; Onuf, 1998). No entanto, o entendimento dos regimes internacionais em operação na sociedade internacional, por exemplo, tanto para racionalistas quanto para alguns reflexivistas por vezes ainda delineia os regimes em sua forma mais tradicional ${ }^{11}$ (cf. Krasner, 1982).

Quanto às instituições, Reus-Smit (1999, p.13) chama de fundamentais as que, na modernidade, são as regras básicas de práticas que estruturam a cooperação nos regimes internacionais; e chama de constitucionais (referidas como "estruturas") aquelas que definem a identidade social do Estado e os parâmetros básicos de ação do Estado de direito ${ }^{12}$. As estruturas incorporam "uma crença hegemônica sobre o propósito moral da organização política centralizada e autônoma, um princípio organizador da soberania e uma norma de justiça procedimental pura” (p. 26). A estrutura na concepção Reus-Smitiana seria, então, responsável por "moldar as imaginações organizacionais dos arquitetos institucionais" e também pelos "discursos morais mais amplos que cercam a produção e reprodução institucional" (p. 27).

\footnotetext{
${ }^{11}$ Regimes são tradicionalmente definidos como "sets of implicit or explicit principles, norms, rules and decision-making procedures around which actors' expectations converge in a given area of international relations" (Krasner, 1982, p. 186), definição esta também usada por Reus-Smit (1999).

12 Seguindo Kennet Waltz (1979), Reus-Smit afirma que as instituições constitucionais são "estruturas", porque elas "limitam e moldam os agentes e as agências e as direcionam de maneiras que tendem a uma qualidade comum de resultados mesmo que os esforços e os objetivos dos agentes e das agências variem" (Reus-Smit, 1997, p. 566; Reus-Smit, 1999, p. 31).
} 
Essa noção institucional é, portanto, desenvolvida sob uma ontologia fora de um marco de racionalidade puramente auto-interessada, e através do entendimento de discursos práticos advindos da teoria da ação comunicativa habermasiana ${ }^{13}$. Sob esta perspectiva, considera-se que, na história, as diferentes sociedades foram governadas por distintas práticas institucionais, crenças e valores que constituíram as normas e estruturas políticas legítimas por meio do discurso, o que explicaria o desenvolvimento de diferentes ordens institucionais.

A explicação de Reus-Smit (1999, p. 28), para a formação/construção institucional dentro da ordem pode ser compreendida por meio dos seguintes discursos práticos:

(I) "Os acordos alcançados através da comunicação devem estar baseados, no final, em razões..."; (II) "nem todas as razões têm o mesmo valor, apenas aquelas que soam como valores de ordem superior, pré-existentes e mutuamente reconhecidos são consideradas válidas..."; e (III) "as razões que carregam o maior peso no discurso prático são aquelas que apelam para ideias compartilhadas, profundamente enraizadas, e coletivas e que definem o quê constitui um agente social legítimo".

Observa-se nessa concepção discursiva que a dimensão normativa e a emergência das instituições é possível tanto pela via estratégica quanto circunstancial considerando-se o contexto de interação cultural e intersubjetiva dos atores. Os valores constitutivos que participam na formação das identidades sociais resultam de crenças intersubjetivas e participam do desenho e das práticas institucionais. Em outras palavras, é através de mecanismos discursivos que ideias intersubjetivas sobre o que é considerado legítimo pelos agentes são conectadas na formação das instituições.

Sob linha semelhante, Onuf (1989) considera que as instituições podem ser consideradas como um dos meios de dar formas ao tecido da sociedade, mas são inconcebíveis sem o exercício da linguagem. Como observa, as formas de vida são produzidas por muitos locutores por meio de acordos, sendo as convenções e instituições, portanto, as que dão forma à vida social (Onuf, 1989, p. 44). No construtivismo de Reus-Smit e Onuf critica-se a abordagem de regimes do

13 "A ação comunicativa envolve um processo de argumento, oferecimento de razões, apresentação de evidência, e compromisso de convencer os outros da validade da própria posição" (Williams, 2003, p. 522 apud CASE Collective, 2006). 
institucionalismo liberal sustentando-se que as propriedades dos regimes internacionais são construções dos agentes/observadores e que autores como Krasner (1982) e Keohane (1984) induzem ao erro nas análises institucionais em virtude de considerar as regras e normas apenas em seu papel regulador. Entretando, Onuf se afasta de Reus-Smit e de outros construtivistas (e.g., Wendt, 1999, na Teoria Social) que apesar de adicionarem a função constitutiva das instituições em suas análises, enxergam uma distinção entre regras constitutivas e reguladoras. Para Onuf (1989, p. 50), "uma vez que todas as regras são simultaneamente constitutivas e reguladoras não deveria ser nenhuma surpresa que os fatos sociais são indistinguíveis dos fatos institucionais na prática”.

Onuf vê as instituições como um conjunto de regras e recursos, que são formadas por acidente ou desígnio por padrões reconhecíveis de regras e práticas afins que servem às intenções dos agentes; elas "tornam pessoas em agentes e constituem um ambiente no qual os agentes conduzem-se racionalmente" (p. 61). Os regimes internacionais então seriam indistinguíveis das instituições, pois os elementos que os compõem - na definição tradicional de regime: princípios, normas, regras e procedimentos - mostram apenas variações de categorias de regras; além disso, os regimes internacionais variam no tamanho e na extensão a qual suas regras endossam outras regras em termos de generalidade, formalidade, número e arranjo (Onuf, 1989, p. 70).

Em contraste com a abordagem construtivista voltada a regras, a abordagem aqui trabalhada considera que as regras, enquanto discursos, variam em seu grau de constitutividade e nem toda regra regula e constitui ao mesmo tempo, pois isso vai depender do privilégio contextual que um determinado significante adquire no espaço político. As regras advindas de demandas consideradas marginalizadas, por exemplo, e que não conseguem apoio social, não funcionam com o mesmo poder institucional que as demandas consideradas prioritárias para uma elite decisória. Quanto ao construtivismo da Teoria Social, o problema está na forma como concebem as identidades, principalmente do que tange as identidades coletivas, ou corporativas (cf. Wendt, 1999), pois ainda que vistas como construtos da linguagem, mantém-se um núcleo que não é fluido, fundamentado num self que não tem espaço para fratura ou (re)construção via interação exterior. Se observarmos a complexidade de um campo social onde se verificam muitas disputas discursivas é possível ver quão delicado é tratar a identidade como algo 
que detém um self particular. Para Laclau (2012), uma identidade particular pura trata-se de um objeto impossível do mesmo modo que o conceito de "centralidade absoluta" é impossível pela consequente ideia de essencialidade que se poderia disso se presumir, pois toda identidade é atravessada por ambuiguidades. Como afirma o autor,

(...) [Y]o creo que una identidad particular es impossible por el mismo motivo de que una centralidad absoluta es impossible. Porque una identidad particular sería algo construido estrictamente sobre la lógica de la diferencia ${ }^{14}$, sería diferente de otras identidades, aplicando el principio saussuriano más elemental, pero no estaría cruzada por ninguna ambigüedad. Entonces, si hay puras particularidades, eso requiere un campo en el cual la diferencia entre esas particularidades se constituye, y entonces se está contrabandeando allí, de nuevo, la idea de fundamento (Laclau 2012, p. 134).

Deste modo, a utilização da análise de discurso está influenciada por uma visão não descritivista da linguagem onde há uma emancipação da ordem do significante, isto é, a identidade e a unidade das coisas resultam da própria operação de nomear, não estando subordinadas a uma descrição ou designação precedente (cf. Laclau, 2005, Žižek, 1989).

\subsection{0 jogo dos discursos: nada é absoluto}

Existe na pesquisa uma pressuposição de que o conceito de humanitarismo está em um processo de ressignificação e uma questão que pode ser colocada, por exemplo, é se isto seria uma inovação do século $\mathrm{XX}$ ou se manifestaria independentemente do contexto histórico. A resposta mais apropriada é: ambas as coisas. Segundo a lógica de Laclau \& Mouffe (1987), podemos afirmar que os entendimentos a respeito da identidade do humanitário e do campo humanitário podem ser vistos como frutos da constituição política do humanitarismo enquanto um campo de articulações. Se, por um lado, temos certas disputas manifestandose com maior visibilidade a partir da segunda metade do século XX, por outro

\footnotetext{
${ }^{14}$ A lógica da diferença não apenas marca a separação entre particularidades que possam servir para definir identidades, mas tem para Laclau (2005) um papel constitutivo na formação de uma sociedade homogênea onde não há predominância de discursos anti-hegemônicos. O caso acima mencionado refere-se à primeira função. A segunda função será revisitada mais adiante.
} 
lado, o sentido de humanidade que constituía a noção de humanitarismo em tempos anteriores são tão frutos de desenvolvimentos históricos e articulações políticas daquele outro contexto normativo quanto do atual. O efeito de fixação de sentidos dependerá do jogo discursivo paralelo e correlacionado à realidade social do momento. A disputa que se manifesta no contexto histórico pode condicionar a emergência de certas cadeias de significantes em detrimento de outras. Temos, como exemplo, as cisões de princípios e diferenciações entre humanitarismo tradicional e novo humanitarismo nos anos 1990 (Fox, 2002).

Em termos teóricos, quando enxergarmos o universo social destes atores podemos compreender como o social e seus aglomerados institucionais se constituem por meio de discursos, uma vez que articulam elementos linguísticos e não linguísticos (Laclau, 2005). O discurso que está delimitado como campo humanitário, sob esta perspectiva, se define como algo para além da linguagem como substância, trata-se da linguagem enquanto forma. $\mathrm{O}$ que interessa são as relações e não os elementos considerados em si mesmos. Para Laclau, o discurso é, pois,

[...] o campo de uma ontologia geral, quer dizer, de uma reflexão acerca do ser enquanto ser. Isto supõe que as categorias linguísticas deixam de estar ancoradas numa ontologia regional que as reduziria à fala e à escrita, e passam a constituir o campo de uma lógica relacional - fundada na substituição e na combinação, as duas formas primárias da articulação - que constituem o horizonte último do ser enquanto tal (Laclau, 2008, p. 189 apud Mendonça, 2012).

A operação de construção dos conceitos no campo discursivo do humanitarismo e suas possíveis ressignificações ao longo do tempo são, portanto, modos de articulação, relações discursivas que têm por base a mesma indeterminação que conforma a realidade social: o vazio ou a vagueza constitutiva que faz com que nenhum significado seja estático, já que nenhum conceito tem suas fronteiras totalmente fechadas à interpelação.

A interpelação dentro do campo humanitário são as propostas, os projetos políticos, os discursos éticos e os símbolos envolvidos na constituição e desafio desse espaço. A multiplicidade de demandas é justamente o que "esvazia" o humanitário enquanto um nome. Os nomes humanitário, humanidade, humano, etc., são signos que adquirem significado apenas quando dentro de uma relação 
com outros significantes; não possuem um significado em si mesmos. Assim se constituem os significantes vazios, os signos que vão significar algo apenas quando, através das cadeias de equivalência, se combinarem com outros signos que lhes vão atribuir significado. Mais formalmente, a definição de Laclau (2005) é de que:

[C]uando hablamos de "significantes vacíos" queremos decir algo enteramente diferente: que existe un punto, dentro del sistema de significación que es constitutivamente irrepresentable; que, en ese sentido, permanece vacío, pero es un vacío que puede ser significado porque es un vacío dentro de la significación. Es como en el caso del análisis que hace Paul de Man del cero de Pascal: el "cero" es la ausencia de número, pero al otorgar un nombre a esa ausencia estoy transformando el "cero" en "uno" (p. 136-137).

Como exemplificado por Laclau, o conceito de "zero" não significa o "nada" ou a ausência de uma unidade. Embora seja a ausência de número, ele se torna "a unidade" quando identificado numa expressão matemática. $\mathrm{O}$ ato de nomeá-lo se torna seu próprio fundamento sendo, portanto, um significante vazio.

Os significantes vazios têm uma função tanto representativa quanto constitutiva e são os que dão unidade à ideia de identidade, grupo, conjunto, povo, partido, etc.; sua natureza vazia vem de uma estrutura contingente, nunca totalmente fechada e historicamente localizada, sendo a "relação" a sua própria ontologia. O vazio resulta de uma irrepresentabilidade da ordem do simbólico e adquire determinada presença discursiva por meio da produção de significantes vazios que dão nome a uma plenitude ausente. A importância deste conceito na análise do "militarismo humanitário", ou "humanitarismo militar", se dá devido a essa falta originária própria do conceito de humanitário, algo que as práticas hegemônicas no mundo globalizado vão tratar de preencher.

Cabe arguir que os dois universos - militar privado e humanitário - não possuem fronteiras bem estabelecidas não apenas porque os discursos nunca são fixos (Laclau \& Mouffe, 1987), mas também porque o mais importante são as relações constitutivas entre os vários elementos de um conjunto de práticas discursivas.

No caso da abertura do humanitarismo a novos atores, uma série de significantes aparecem e desaparecem na prática discursiva, mas alguns são mais privilegiados que outros. Alguns princípios no humanitarismo conseguiram se 
estabelecer por muito tempo e outros se tornaram regras menos formais, mas o processo articulatório é contínuo e a contingência não permite que haja um fechamento total para os conceitos. A referência que se faz aos processos de ressignificação dos discursos tampouco pressupõe um movimento fluido imparável dos discursos. A relação entre materialidade e linguagem é dinâmica, porém impensável sem certas reificações. Em alguns momentos, a referência a definições aparentemente fechadas, sentidos aparentemente fixos, são feitos por meio de reificações enquanto construtos necessários para dar o mínimo de sentido à vida social. Como bem coloca Neumann (2008, p.74), "temos que classificar novos fenômenos em categorias já existentes a fim de obter sucesso em nossas vidas. Argumentar que tudo é igualmente fluido torna impossível analisar algo em seu contexto social".

Deste modo, a fixação parcial dos sentidos num determinado momento histórico nos permite identificar quais são as contradições para os atores humanitários, analistas e demais atores sociais que lidam com os argumentos que desafiam a ordem do microcosmo do sistema de ajuda humanitária.

A prática humanitária, por mais de um século, tem se mantido como um pungente tema para indicar contradições. Por um lado, é defendida como a forma menos imoral de se atenuar os efeitos das guerras e, por outro, como política de poder, de modo que não apenas permitiria a perpetuação das guerras, mas delas dependeria para que a institucionalização da cultura da ação humanitária não desapareça. Existe, assim, uma relação entre o militarismo e humanitarismo que não é novidade; pelo contrário, são coincidentes e concomitantes. Mas até que ponto são paralelos e até que ponto se atravessam? Embora não seja o objetivo da dissertação identificar genealogicamente a relação simbiótica entre militares e humanitários, quando consideramos algumas mudanças no curso da história e as oportunidades de novas interpretações das políticas de poder no campo humanitário, podemos identificar a formação de novas posições políticas e posições de sujeito neste complexo campo da ajuda humanitária. É complexo devido à dificuldade em se delimitar as fronteiras que compõem o universo do humanitarismo; e é campo, porque embora nunca fechado, o espaço de ação de agentes que utilizam narrativas humanitárias precisa de alguma delimitação heurística para se fazer compreensível em nossa análise, algo que se dá pela intensidade das formações agonísticas e antagonísticas nesse espaço. 
Dito isto, o processo de agenciamento dentro do campo humanitário de instituições cuja natureza histórica advém de outro campo de ação, no presente caso da segurança privada, é considerada uma "contradição" quando o recorte analítico enfatiza a premissa da não militarização de um campo que agora pode ser militarizado.

Mas, como já argumentado, a complementariedade entre grupos de naturezas distintas nunca é impossível ou improvável. Temos, por exemplo, no sistema econômico moderno um marco para proliferação dessas complementaridades ditas contraditórias, vide a divisão e especialização do trabalho e a permissividade para que toda sorte de instituições trabalhem separadamente, ao mesmo tempo, e com a mesma finalidade. No caso do setor de ajuda e alívio, a lógica da divisão de trabalho e da eficiência permite que agências humanitárias ou de desenvolvimento cheguem a contratar provedores de segurança privada - Sudão, Somália e Iraque são casos mais conhecidos - e o fato de este tipo de contratação não ter existido antes dos anos 1990 leva-nos a investigar se, atualmente, ocorrem mudanças na estrutura do humanitarismo que justifiquem este tipo de contratação.

Quando se observa a história do engajamento entre agências humanitárias e empresas de segurança privada podemos inferir que o contrato estipulando que estas empresas cuidem da proteção dos trabalhadores humanitários é uma das resultantes da lógica de divisão do trabalho acima mencionado mediante certas demandas por segurança advindas do próprio campo humanitário. Entretanto, uma interrogação se coloca sobre casos em que o paralelismo dessa relação extrapola os limites, até então considerados, da natureza institucional de cada agência. A possibilidade de se tornar difícil distinguir a diferença entre as práticas humanitárias empreendidas pelas EMSPs e as práticas das agências humanitárias é um oxímoro para os moldes do humanitarismo tradicionalista. Naturalmente, esse extrapolamento não é assim considerado consensualmente, mas em geral criticam-se as EMSPs por sua tomada de tarefas e racionalidades do universo discursivo humanitário.

A discussão se torna mais calorosa à medida que as empresas se apropriam de certos papéis que os humanitários tradicionalmente ${ }^{15}$ desempenhavam de modo

15 Observe, pois, que "tradicionalmente" se refere às práticas humanitárias modernas cuja instituição de referência é o Comitê Internacional da Cruz Vermelha (CICV). 
a torná-los parte de seu portfólio institucional. No entanto, para além das questões levantadas quanto ao fenômeno da privatização da segurança após a Guerra Fria a relação muitas vezes direta das EMSPs com agências de ajuda humanitária faz emergir outras contraposições e paradoxos.

A política que emerge desse espaço pode ser observada nas colisões que ambas as instituições exprimem quando expõem suas narrativas de proteção. Da parte das EMSPs, o argumento da eficiência reflete a necessidade da utilização de indistintos meios para se chegar ao almejado fim: cumprir com a agenda de quem os contratou. Da parte das agências humanitárias, o argumento se subdivide em duas lógicas: a lógica deontológica ${ }^{16}$, que reflete a necessidade de se aliviar o sofrimento humano até o ponto em que a neutralidade, a imparcialidade e a independência destas agências não sejam prejudicadas; e a lógica consequencialista $^{17}$, onde o alívio do sofrimento humano é meta-orientado para além dos casos emergenciais e que se permite aproximar de determinadas agendas políticas; pois, segundo esta lógica, isso seria favorável às populações receptoras da ajuda humanitária.

Estas duas lógicas podem ser consideradas a expressão mais polarizada do antagonismo político do humanitarismo na sociedade moderna, mas elas já podiam ser encontradas há mais de um século sob a forma de discursos particulares. Barnett (2011), por exemplo, sugere que estes discursos existem pelo menos desde o século XVIII e os identifica, respectivamente, como humanitarismo emergencial e humanitarismo alquímico. O primeiro é voltado para alívio de pessoas em perigo ou sofrimento imediato, guiado por princípios de imparcialidade, neutralidade e independência; o segundo foca nas causas do sofrimento e busca a transformação do contexto emergencial por meio do conhecimento e da capacidade técnica via intervenções de distintas naturezas, onde a política é um elemento necessário para a ação humanitária (Barnett, 2011, p. $37-41)^{18}$. Enquanto que organizações como o CICV e o MSF seriam

\footnotetext{
${ }^{16}$ A lógica deontológica é sugerida por Barnett (2005).

17 A lógica consequencialista é uma expressão adaptada da noção de "ética consequencialista mencionada" em Barnett (2005, p. 732), mas pode ser encontrada em Fox (2002) sob a nomenclatura das ações "meta-orientadas" ou "desenvolvimentistas". A separação que sugiro, contudo, tem por inspiração as categorias expressadas nos imperativos categórico e hipotético da Fundamentação da Metafísica dos Costumes (1785) de Emmanuel Kant.

${ }^{18}$ Vale ressaltar algumas semelhanças e diferenças entre a abordagem de Barnett (2011) e a proposta aqui conduzida. Barnett habilmente analisa o diálogo contínuo dessas duas lógicas em três épocas distintas, que chama de Humanitarismo Imperial (da Revolução Francesa à Segunda Guerra Mundial), Neo-Humanitarismo (da Segunda Guerra Mundial até o fim da Guerra Fria) e
} 
representantes da primeira lógica, outras organizações como o Oxfam, CARE, Catholic Relief Services (CRS), World Vision International (WVI) e algumas agências da ONU seriam exemplos do segundo grupo (Barnett, 2011).

Temos aqui em disputa, portanto, duas demandas por legitimação da prática da ajuda e alívio; a primeira se refere aos "humanitários tradicionais" e a segunda se refere aos "novos humanitários". Ambos, entretanto, por vezes vocalizam uma justificativa em comum: atuar em nome da humanidade.

Existem, no entanto, significados concorrentes a respeito da humanidade; e o processo de agenciamento das EMSPs - assim como foi no surgimento dos novos humanitários - se constitui à medida que estes atores entram no jogo discursivo que busca deter o poder de definir o significado do que é humanitário. Todavia, em nome da humanidade-humanitária um campo normativo/discursivo é capaz de acomodar agências cujas naturezas são consideradas opostas, e devemos partir, portanto, de algum critério para compreender o fenômeno no tempo e espaço. Para chegarmos a tal critério duas questões devem ser feitas: Seriam as agências humanitárias e as empresas privadas capazes de atuar coerentemente em nome do humanitarismo? Se sim, qual o fundamento epistemológico dessa humanidade que forma o nome humanitário?

A resposta é que nem uma ou outra agência seria capaz de cumprir a totalidade do discurso que defendem em nome da humanidade, pois a humanidade é um objeto impossível. A impossibilidade é o próprio fundamento epistêmico da humanidade e é isso que o torna um significante vazio e capaz de ser apropriado por agências de naturezas das mais diversas.

Humanitarismo Liberal (de 1989 até o presente). Nestes três marcos temporais, Barnett conduz alguns recortes que esta dissertação poderia conceber como três grandes configurações de totalidade no Campo Geral da Discursividade Humanitária da era moderna e creio que seja um tema produtivo para ser desenvolvido por acadêmicos reflexivistas. No que tange às distintas forças de produção, destruição e compaixão que influenciaram as transições entre uma era e outra, Barnett (2011) nos oferece importantes discursos que trabalharam como significantes privilegiados em cada era, entretanto, a abordagem do autor não concebe outras forças históricas por ele mesmo mencionadas como parte de uma disputa discursiva. A separação das três eras não concebe a noção de fronteira aberta e de ressignificação, que podem identificar a ideia de reconstrução de estados, por exemplo, não como nova, mas como ressignificada no pós-Guerra Fria, uma vez que, no final do século XIX, grupos humanitários detinham ambições semelhantes nos territórios coloniais europeus e mais além como observou Rodogno (2011) em sua menção às intervenções multilaterais e ocupações territoriais nas províncias otomanas de Creta e Macedônia. Outro exemplo de articulação que perpassa a ideia das eras de Barnett seria o discurso do "desenvolvimento" (Rodogno, 2012) que precedeu a década de 1990 articulado sob a forma de "modernização", sendo trabalhado como medida anticomunista preventiva e remediativa durante a Guerra Fria. 


\subsection{Argumento central}

$\mathrm{O}$ argumento central que aqui se defende é de que o agenciamento das EMSPs se dá no campo humanitário que é um conjunto de discursos circundantes, que, em perspectiva, podem estar sempre em contradição. Porém, neste espaço de contradição existe convergência, divergência e muitas vezes consenso, lugar este que podemos nos referir como campo geral da discursividade humanitária. Neste campo, vários conjuntos de atores vocalizam suas demandas para definir o significado do humanitarismo, sejam eles os receptores da assistência humanitária, os humanitários tradicionais, os novos humanitários ou as empresas de segurança privada, para citar alguns. Os três últimos recebem maior atenção devido à lógica equivalencial a qual se inserem e porque têm angariado notável capacidade de manejar certas narrativas em função do progressivo poder de agência que adquirem no campo. Estes atores trabalham de modo a formar cadeias de equivalências por meio de lutas e convergências políticas. Quando mais disputado é o humanitarismo na política do campo humanitário, "mais vazio" se torna este significante. Muito embora o objetivo aqui seja identificar o processo político de agenciamento nesse campo, um potencial efeito dessa política é a configuração de uma nova formação hegemônica no campo geral da discursividade humanitária.

Ressalto que este trabalho não se trata de uma pesquisa de campo, tampouco de uma análise sociológica das relações entre os agentes na ajuda humanitária. Trata-se de uma análise discursiva sobre possibilidades que se baseiam em enunciados recorrentes no universo das agências humanitárias e das empresas de segurança privada. A constituição da agência das EMSPs se forma num campo onde outras disputas já estão em jogo e há sempre possibilidades de amalgamento de demandas. Esse amalgamento se dá por um processo de formação de uma cadeia de demandas cada vez mais equivalentes (lógica equivalencial), ou segundo o conceito de Laclau \& Mouffe (1987), uma cadeia de equivalências.

A dissertação concebe que a constituição de agência num determinado campo de atuação é fruto de uma construção discursiva feita por meio de narrativas e práticas. A legitimação da agência pode emergir da aquiescência verbal ou não verbal a respeito da permanência dos atores no campo. Firmar contratos com empresas, por exemplo, sugere a concordância formal da prática 
desta empresa. A aquiescência por meio de cooptação também se faz possível mediante casos em que, por exemplo, as oportunidades de trabalho são escassas em sociedades destruídas por conflitos ou desastres naturais onde EMSPs podem oferecer benefícios a indivíduos da população local em troca de informação. Estes indivíduos, de outro modo, podem se portar de modo totalmente resiliente, sendo parte de um grupo que antagoniza a cadeia equivalencial das EMSPs no campo, ou ser parte de outros grupos mais marginalizados em sua capacidade de expressarem agência e suas demandas diferenciais, que como se verá na seção a seguir são discursos que podem ser considerados como elementos.

\subsection{As narrativas marginais do campo humanitário}

Um dos maiores desafios para o mapeamento de discursos que permeiam o campo humanitário está na capacidade de igualmente considerar todas as vozes que formam a realidade sendo estruturada. As diferenças de poder definem quais narrativas são privilegiadas e quais são marginalizadas. No que tange ao discurso da população local sobre sua perspectiva perante a presença das EMSPs em seu território, sabe-se que muito raramente têm a oportunidade de pronunciarem suas demandas, e quando se pronunciam, são discursos geralmente postos à margem. Dificilmente se encontram dispositivos de reverberação para as vozes locais e, quando audíveis, são consideradas como um recurso para introdução de projetos oferecidos por organizações ocidentais ou um meio para facilitar acordos, aceitação ou a chegada de atores militares ou humanitários no campo.

Os receptores de assistência humanitária, ao não conseguirem se firmar como representantes de si mesmos ou como portadores um projeto político antagônico às demais agendas humanitárias, acabam por ter suas demandas dissipadas em meio à pluralidade de questões por eles enfrentadas diariamente. A falta de recursos de diversas naturezas transforma as narrativas da população local em um conjunto de discursos cujos significantes não são capazes de se estabelecer na vasta cadeia discursiva humanitária. Tomemos, como exemplo, as noções de "autodeterminação" e "liberdade" como um direito de ir e vir. Quando se tornam narrativas da população local, estas demandas encontram barreiras quase que insuperáveis mediante discursos tais como: os da vulnerabilidade política do 
Estado falido, o resguardo da segurança individual no espaço humanitário, a impossibilidade de alteração das regras antes de um cessar-fogo, a necessidade de respeito aos horários pré-estabelecidos para movimentação dentro e fora das áreas de risco, a compreensão de que o alto grau de insegurança requer guardas armados dentro do campo, entre outros. Dentro da cadeia discursiva do humanitarismo, os discursos da margem geralmente passam por dois caminhos: ou permanecem como demandas esparsas, que surgem e se vão com certa esporadicidade, ou, de algum modo conseguem entrar em equivalência com outras demandas do campo humanitário, formando uma nova cadeia de equivalência ${ }^{19}$.

No caso desta pesquisa, o processo de reformulação do campo discursivo humanitário concebe estas demandas marginais como elementos, isto é, aqueles discursos cujo significado é constantemente contestado e que não conseguem ser articulados em uma cadeia discursiva. Chamam-se momentos os elementos que foram, em parte, fixados em relação a outros momentos ou pontos nodais (Laclau \& Mouffe, 1987). Estes discursos contestados podem se tornar significantes flutuantes ao não conseguirem se articular em uma cadeia discursiva. Os significantes flutuantes são aqueles cujos sentidos permanecem suspensos mediante conjuntos de discursos rivais que podem tentar cooptá-los. O particularismo de um significante flutuante assim o torna por não ter sido articulado em uma cadeia equivalencial e seu significado fica indeterminado entre fronteiras equivalenciais alternativas (cf. Laclau, 2005, p. 165).

Os discursos dos receptores da assistência humanitária são geralmente mediados por grandes organizações que podem ou não reproduzir com precisão suas narrativas. Se, porventura, as vozes recessivas se tornam agendas, estas serão geralmente intermediadas por humanitários cujas instituições detêm os recursos de transmissão de suas ideias e ideais. Neste caso, contudo, este seria um processo que configuraria outra lógica equivalencial juntamente com estas agências.

Um exemplo de aproximação de ideias entre agências e pessoas locais que poderia iniciar uma lógica equivalencial, poderia ser a política chamada de "sem

\footnotetext{
${ }^{19}$ Temos no processo de crescimento de grupos fundamentalistas político-religiosos, um exemplo de lógica equivalencial, onde uma variedade de demandas é processada por um discurso que assume o papel de articulador das vozes insatisfeitas em determinada sociedade, ainda que muito diferente dos discursos originais. Grupos que se encontram constantemente marginalizados muitas vezes optam ou são cooptados em caminhos discursivos que podem desviar-se da lei ou de uma moralidade antes valorizada dentro desse grupo. A insatisfação pode se originar como uma crítica ao sistema de saúde local e desemprego indo até a discordância sobre direitos matrimoniais, culturais, de gênero, etc.
} 
armas" nos estabelecimentos de saúde afegãos onde trabalha o MSF, uma vez que é tanto fruto da desconfiança e insatisfação dos indivíduos locais quanto uma preocupação da própria organização. A importância desse programa num país como o Afeganistão, segundo o MSF (2010), foi resultado de acordos entre todas as partes em conflito. Para a segurança dos pacientes, considerou-se como fundamental que somente pessoas não armadas se aproximassem dos hospitais, uma vez que a presença de indivíduos armados tornaria as instalações um potencial alvo de guerra.

Segundo o MSF (2010), este é um princípio de neutralidade que na maioria das situações de conflito já está estabelecido nos centros de saúde e hospitais, mas no Afeganistão ele é incomum por haver "uma configuração de conflito onde se testemunha uma grande presença de pessoas armadas dentro das instalações de saúde" e isso inclui "forças internacionais, guardas de segurança privada, policiais locais, exército local, e outras pessoas armadas não identificadas. Em uma situação como esta, é impossível pedir as partes em conflito de se absterem de atacar o hospital". Em 2010, quando perguntado sobre os obstáculos enfrentados por afegãos que tentam chegar no Hospital Boost, na Província de Helmand, o representante do MSF Michiel Hofman, faz a seguinte afirmação sobre o que ouvira da população local:

From anecdotal evidence, mainly from patients telling us their stories, it seems that the biggest barrier for people from this region is insecurity. To travel even a short distance can be both hazardous and expensive, as transport costs increase with insecurity. Other factors are that the hospital's services are either unknown or mistrusted, meaning people prefer to go to private clinics, or else to Pakistan. Once MSF has a better idea of the main barriers that prevent people from accessing health care in the most critical regions, we intend to invest more in early detection and safe referral systems (MSF, 2010).

Três anos antes deste relato, um grupo de pesquisadores do Swisspeace (2007) coordenou um grupo de discussão ${ }^{20}$ com membros de organizações da sociedade civil afegã para registrar suas impressões a respeito das EMSPs. Os pesquisadores relaram que, no que diz respeito à população local, há um grande grau de confusão quanto à natureza do atendimento e dos serviços que as EMSPs

${ }^{20} \mathrm{O}$ método utilizado pelos pesquisadores do Swisspeace em contato com a população local do Afeganistão foram entrevistas semiestruturadas com as partes interessadas e discussões em grupos focais com a população civil em três regiões diferentes do país (Swisspeace, 2007, p. 06). 
fornecem. "Por que eles estão aqui, o que eles querem, quem são eles?"21, questiona um civil entrevistado em Cabul.

A falta de transparência contribui para uma indefinição entre as EMSPs internacionais e outros atores militares tais como: a Força de Assistência à Segurança Internacional (ISAF/NATO ou as forças da coalizão), a equipe das empresas de segurança privada, o pessoal da comunidade civil internacional, as EMSPs locais, os grupos armados ilegais as forças de segurança local (Swisspeace, 2007, p. 06).

De maneira geral, a população local se refere às EMSPs de modo negativo no Afeganistão, uma vez que consideram que as empresas guardam a vida dos seus clientes sem aumentar a segurança da população em geral ${ }^{22}$. Os entrevistados sugeriram que a presença de EMSPs levaria, na verdade, a um sentimento de desconfiança ou mesmo de insegurança. Uma das razões seria a legitimação e o fortalecimento dos detentores do poder local e das milícias uma vez que as EMSPs por vezes os contratam ou colaboram com estes; eles também mencionam a intimidação provocada pelo "armamento pesado (que carregam), o comportamento grosseiro para com a população local, relatos de ligações de EMSPs com atividades criminosas e a preocupação de que EMSPs desviem recursos escassos da reconstrução do Afeganistão, tendo em conta os elevados custos de seus serviços” (p. 06).

Alguns senhores em $\mathrm{Cabul}^{23}$ se referem às forças de segurança internacional como "um bando de americanos" independentemente de quem representam. A população local entrevistada, tanto em áreas urbanas quanto rurais, relatou as mesmas dificuldades de diferenciação entre pessoas, unidades pertencentes a atores militares e outras organizações no campo. As empresas de segurança privada são geralmente associadas a forças tais como o do exército dos EUA, por exemplo, e não como como entidades independentes (Swisspeace, 2007), além de levantarem dúvidas sobre como responsabilizar as EMSPs. Como afirmou um dos entrevistados:

\footnotetext{
${ }^{21}$ Entrevista conduzida no Focal Group Discussions em 29 de março de 2007 (Swisspeace, 2007). ${ }^{22}$ Segundo revelado no Focal Group Discussions de maio 2007 (Swisspeace, 2007), os entrevistados não sentiam que as EMSPs tivessem um impacto positivo sobre sua "segurança humana", pois, como no relato de um senhor afegão, as EMSPs são vistas como trabalhando exclusivamente para os "internacionais, especialmente aqueles que não estão tão familiarizados com o terreno no Afeganistão" (p. 32).

${ }^{23}$ Focal Group discussion, Cabul, Maio 2007 (Swisspeace, 2007).
} 
We may also have problems with ANA [Afghan National Army] and ANP [Afghan National Police], but at least on paper there are rules put down for them, they are part of the government. At least we know where to go and complain. What about PSCs, if something happens, where should we go to complain, what should we do about if we have problems? ${ }^{24}$

Em Cabul, a população local expressa a insatisfação em não poder acessar pessoas e locais antes permitidos que agora estão bloqueados por 'questões de segurança' (Swisspeace, 2007), e as justificativas advêm de toda sorte de relatórios de organizações internacionais.

No Quênia, por outro lado, a experiência de alguns humanitários locais sobre a segurança nos campos de Dadaab foi de que havia uma sensação de insegurança em algumas instalações que só eram mantidas por guardas desarmados. Eles não vinham todas as atividades das EMSPs como negativas e consideravam a importância de programas de segurança oferecidos por estas empresas como preparação para possíveis riscos. O relato de uma queniana, assistente de programas de uma ONG em Dadaab foi: "I wouldn't say they make me feel safer but they make me more knowledgeable and when I get information I know how to react in different situations" (Rudolph, 2013, p. 82).

Estes relatos, como já mencionado, são exemplos de expressões das vozes locais que muito raramente conseguem se expressar significativamente, pois a marginalização da opinião dos habitantes locais de países receptores de ajuda humanitária se verifica na pouca referência textual recebida. E no desprivilégio de não poder se fazer ouvir muitas vezes recorre-se à resistência violenta nos campos.

Para citar um exemplo, no $27^{\circ}$ relatório do Humanitarian Policy Group, um relevante grupo de pesquisa financiado pelo Overseas Development Institute, encontramos uma expressiva descrição do método de pesquisa e avaliação utilizado para produzir as representações gráficas e comparações estatísticas no que tange ao uso das EMSPs em operações humanitárias. O grupo menciona uma ampla gama de referências e entrevistas que viriam a compor o estudo apresentado no documento. Citam-se 350 entrevistas semiestruturadas entre tomadores de decisão, políticos e profissionais dos setores de segurança e de ajuda humanitária. Cerca de 65 entrevistas foram realizadas dentro das sedes das

\footnotetext{
${ }^{24}$ Focus group discussion, Cabul, 29 Mar. 2007 (Swisspeace, 2007).
} 
organizações enquanto que o restante foi feito no campo. Os pesquisadores entrevistaram agentes da ONU, de ONGs, Cruz Vermelha e Crescente Vermelho e representantes dos doadores. Somente para este relatório foram feitos seis estudos de caso com cerca de 250 funcionários de campo que foram entrevistados nas capitais e nas regiões operacionais. Os entrevistados incluíam funcionários da ONU, da equipe internacional das ONGs, representantes interinstitucionais, funcionários de ONGs locais e agentes das empresas de segurança privada e do governo (HPG, 2006, p. 09), mas em nenhum momento foi mencionado que um habitante local tenha sido entrevistado ou que sua opinião pudesse ser considerada como fonte primária da organização dos dados. Deste modo, percebe-se que nas operações de ajuda humanitária, as narrativas chamadas locais são, portanto, majoritariamente transvestidas pelas globais.

\subsection{As articulações discursivas que atravessam o campo humanitário}

Se pensarmos nas condições modernas que precederam o humanitarismo em termos morais, a maior parte das referências que poderíamos encontrar fora do âmbito exclusivamente privado seriam em relação à compaixão ou solidariedade entre humanos pertentes a uma mesma comunidade. No pensamento ocidental, o ciclo filosófico francês popularizou o termo humanité no século XVIII, que denotava a preocupação do humano pelo bem estar de seus semelhantes (Mcloy, 1957 apud Barnett, 2011) e isso influenciaria o direito internacional moderno por meio do jurista Emmerich Vattel em sua publicação Offices d'humanité, conhecido como "as obrigações humanitárias" das nações civilizadas (Barnett, 2011). Em termos jurídicos, com a norma civilizacional que pairava ainda no pensamento do século XIX, a noção de humanidade já dava sentido a uma norma humanitária mais legalista referindo-se à ausência de hostilidade no campo de batalha, o que denotaria o conceito próprio de neutralidade. A representação simbólica era o corpo ferido ou doente do combatente no contexto de guerra que já não era mais visto como ameaça, isto é, o significante humanidade passava a ser proporcional ao significado da neutralidade. No entanto, o significado da neutralidade ainda comportava apenas o referente da civilização e somente mais 
tarde o processo de ressignificação da humanidade conduziria seu significado a expressar um sentido mais complexo ${ }^{25}$.

Ainda no século XIX, uma noção mais enxuta de humanidade pode ser encontrada em documentos como o de Francis Lieber, mentor do código que leva seu nome, construído em 1863 com o objetivo de regular a conduta das tropas da União durante a Guerra de Secessão Americana. No código, considerava-se que as "nações modernas civilizadas" constituíam-se como tal mediante a conformidade com as "medidas indispensáveis para assegurar as finalidades da guerra" (General Orders n 100, 1863, Art. 14, Art. 20), e algumas destas medidas inauguraram justamente a separação identitária crucial para as normas humanitárias codificadas alguns anos depois ${ }^{26}$ : a distinção entre inimigo público e indivíduo privado o que, consequentemente, dava forma à noção de neutralidade.

A formação dessa fronteira diferencial iria igualmente indicar o direcionamento civilizado da morte. $\mathrm{O}$ inimigo era apenas o que representava uma ameaça existencial, os demais deveriam ser preservados e protegidos, isto é, os soldados doentes e feridos. Uma vez que não fossem mais ameaças existenciais, deixariam sua identificação como inimigos públicos. Vê-se que a norma humanitária na era de Lieber codificava-se sob a separação entre uma dimensão pública e outra privada, mas sem extensão de direitos humanitários às nações consideradas bárbaras, como se verifica na ausência de restrições militares e legais sobre a ação dos militares dos EUA em relação aos habitantes nativos americanos nos territórios conquistados.

Os indivíduos privados não eram, pois, neutralizados porque eram humanos, mas porque não eram mais combatentes de guerra. A racionalidade por detrás dessa separação pode ser encontrada, por exemplo, nas afirmações dos artigos 22, 23 e 24 (General Orders n ${ }^{\circ}$ 100, 1863) do Código Lieber, a seguir:

Nevertheless, as civilization has advanced during the last centuries, so has likewise steadily advanced, especially in war on land, the distinction between the private individual belonging to a hostile country and the hostile country itself, with its men in arms. The

${ }^{25}$ Como observa Barnett (2011), os Estados e as organizações humanitárias reorganizaram a arquitetura do humanitarismo de modo mais global em torno dos princípios da humanidade, uma vez que, antes voltados à Europa, as agências começaram a enxergar "outros" que não os seus iguais na provisão de ajudas básicas, como na China, Korea, Sul da Ásia e Oriente Médio, que não podiam ser mais ignorados e mereciam ajuda tanto quanto os franceses e os derrotados alemães (p. 108).

${ }^{26}$ Vide exemplos de vários manuais de exércitos de países europeus, como citados no capítulo 2. 
principle has been more and more acknowledged that the unarmed citizen is to be spared in person, property, and honor as much as the exigencies of war will admit (Art. 22)

Private citizens are no longer murdered, enslaved, or carried off to distant parts, and the inoffensive individual is as little disturbed in his private relations as the commander of the hostile troops can afford to grant in the overruling demands of a vigorous war (Art. 23). The almost universal rule in remote times was, and continues to be with barbarous armies, that the private individual of the hostile country is destined to suffer every privation of liberty and protection, and every disruption of family ties. Protection was, and still is with uncivilized people, the exception (Art. 24).

In modern regular wars of the Europeans, and their descendants in other portions of the globe, protection of the inoffensive citizen of the hostile country is the rule; privation and disturbance of private relations are the exceptions (Art. 25).

O Código Lieber, que seria considerado um dos precedentes discursivos para o que veio a se estabelecer como $\mathrm{DIH}^{27}$, deu, portanto, possibilidade à mudança, ou separação, de duas importantes ideias de totalidade na história do humanitarismo ${ }^{28}$ :

(i) Uma totalidade separa as nações civilizadas daquelas de "tempos remotos" (bárbaras), que utiliza os "princípios de justiça, fé e honra" (General Orders $\mathrm{n}^{\circ}$ 100, Art. 30) como as restrições que diferenciam as primeiras das últimas. Aqui o tecido social é formado por indivíduos que são, antes de tudo, nacionais de algum Estado ou governo. Esta totalidade privilegiada é o sistema de Estados.

(ii) A outra totalidade separa os indivíduos nacionais daqueles que não se fazem representar pela nação, trata-se do humano como identidade mais elementar. Aqui a suposição é de que, antes de tudo, o tecido social é formado por indivíduos humanos e o indivíduo humano precede a ideia de nacionalidade. Esta totalidade é a humanidade como um todo, mais cosmopolita, e se desenvolveu desafiando a lógica civilizacional principalmente a partir das duas grandes guerras europeias e da descolonização da África.

\footnotetext{
${ }^{27}$ Menções sobre a influência do Código Lieber no DIH e em outros documentos podem ser encontradas em Roberts and Guelff (1989), Mcfarlane \& Khong (2006) e Kennedy (2004).

28 Esta separação foi, de modo mais elementar, sugerida em 2012 pelo professor Paulo Luiz Moreaux Lavigne Esteves quando lecionava a disciplina "Agentes, Estrutura e Ação Humanitária" para a pós-graduação na PUC-Rio. No entanto, Esteves trabalha a noção de "humanidade", enquanto parte constitutiva do regime internacional de poder que, juntamente com a noção de "globo", rearticula a relação entre o universal e o particular como novos guias da vida prática no então chamado "Internacional Moderno" (Esteves, 2008, p. 20).
} 
O deslocamento de sentido no significante humanidade vai, portanto, do campo estatal para uma ideia mais universalista de pertencimento ${ }^{29}$, e consequentemente, sua direta relação com a neutralidade é alvo da mesma expansão. As Convenções de Haia de 1907 e de Genebra de 1949 expressam bastante a primeira totalidade, enquanto que os Protocolos I e II das Convenções de Genebra de 1977 expressam mais a segunda totalidade. Como exemplo, seguem-se duas extrações da "Convenção V de Haia sobre os direitos e deveres das potências neutras e pessoas em caso de guerra terrestre":

A neutral Power may authorize the passage over its territory of the sick and wounded belonging to the belligerent armies, on condition that the trains bringing them shall carry neither personnel nor war material. In such a case, the neutral Power is bound to take whatever measures of safety and control are necessary for the purpose.

The sick or wounded brought under the these conditions into neutral territory by one of the belligerents, and belonging to the hostile party, must be guarded by the neutral Power so as to ensure their not taking part again in the military operations. The same duty shall devolve on the neutral State with regard to wounded or sick of the other army who may be committed to its care (Art. 14).

The nationals of a State which is not taking part in the war are considered as neutrals (Art. 16).

As posições subjetivas articuladas na regra geral do campo discursivo militar até um determinado momento eram, portanto, as de que o soldado saudável era 'inimigo' e o soldado ferido era 'neutro', expandindo-se, posteriormente, a categoria 'neutro' à pessoa do protetor humanitário e ao indivíduo civil pelo reconhecimento de que sua dimensão privada não alteraria a distribuição de forças no conflito.

A partir das convenções de Genebra já se começava vislumbrar no discurso legal um movimento de abertura e expansão da neutralidade que não se atinha exclusivamente à chave dos conflitos armados internacionais. A neutralidade que começava a ganhar importância em textos legais internacionais no final do século XIX deixava de ser exclusividade do status jurídico de um Estado para abranger vítimas de conflitos civis. A neutralização dos indivíduos sob o aspecto da proteção legal das Convenções de Genebra ${ }^{30}$ seguiu o seguinte caminho:

\footnotetext{
${ }^{29}$ Alguns autores identificam esta mudança como efeito da construção de uma outra moralidade: a norma médica (Debrix, 1999; Esteves, 2008).

${ }^{30}$ Fonte: http://www.icrc.org/eng/war-and-law/treaties-customary-law/geneva-conventions/.
} 
Convenção da Cruz Vermelha, 1864: Melhorar a Situação dos Feridos no Campo de Batalha;

Convenção I de Genebra, 1949: feridos e doentes das forças armadas em campanha;

Convenção II de Genebra, 1949: feridos, doentes e náufragos das forças armadas no mar;

Convenção III de Genebra, 1949: prisioneiros de guerra;

Convenção IV de Genebra, 1949: proteção das pessoas civis em tempo de guerra;

Protocolo I Adicional às Convenções de Genebra, 1977: proteção das vítimas dos conflitos armados internacionais;

Protocolo II Adicional às Convenções de Genebra, 1977: proteção das vítimas dos conflitos armados não internacionais.

Nas convenções, as noções de público e privado estão implicitamente localizadas na diferenciação qualitativa que se cria no ato de neutralização da figura antes pública do soldado. Na condição de ferido ou doente, ele recai na qualidade de indivíduo privado juntamente às pessoas civis em contextos de conflitos armados.

A questão que se coloca neste momento é: qual o lugar dos militares que não são soldados públicos, mas não recaem nas exigências de neutralidade das convenções no que tange à capacidade hostil? Este é o caso das EMSPs cujo status ainda se discurte no âmbito internacional, mas alguns documentos podem sugerir algumas indicações. O Montreux Document $(2008)^{31}$, por exemplo, na Parte I, oferece as seguintes obrigações para as EMSPs:

The status of the personnel of PMSCs is determined by international humanitarian law, on a case by case basis, in particular according to the nature and circumstances of the functions in which they are involved (parag. 24). If they are civilians under international humanitarian law, the personnel of PMSCs may not be the object of attack, unless and for such time as they directly participate in hostilities (parag. 25).

Em outras palavras, a figura do soldado privado tem status neutralizado a menos que se estabeleça o contrário. Seu status vai depender da ordem discursiva

\footnotetext{
${ }^{31}$ Este documento foi concebido pelo governo suíço juntamente com o CICV e aprovada por 17 países em setembro de 2008, mas como a iniciativa está centrada no Estado ainda carece de um esforço semelhante sobre o papel das EMSPs para com as organizações humanitárias internacionais (HPG Policy Brief 33, 2009).
} 
emergindo da situação humanitária a qual estão inseridos, algo extremamente arbitrário dado à assimetria de poder entre os habitantes locais, geralmente as maiores vítimas, e os demais atores internacionais. Outro exemplo relevante é expresso no documento mais importante de padronização da qualidade das Empresas de Segurança Privada do American National Standard, conhecido como “ANSI/ASIS PSC.1 2012”. No documento afirma-se que:

During armed conflict, the personnel of PSCs are normally considered civilians under IHL. As civilians, PSC Personnel may not be object of direct attack unless and for such time as they direct participate in hostilities. (...) PSC personnel cannot, for example, attack enemy armed forces or defend a military objective against an attack by enemy armed forces without losing their protection as civilians (ANSI/ASIS PSC.1 2012, p. 36).

A ambiguidade identitária de um soldado de segurança privada demonstra como o aprofundamento do engajamento humanitário por parte das EMSPs não apenas desafia a separação entre público e privado, mas também a velha noção de neutralidade, uma vez que sua imagem continua ligada à distribuição de forças no campo.

Assim como existia uma relação entre a humanidade e a neutralidade no humanitarismo que privilegiava o aspecto militar público, igualmente há uma relação da humanidade com o aspecto privado militar articulado nos discursos das EMSPs. Trata-se da humanidade dos direitos humanos cuja expressividade nas últimas décadas daria condições para que EMSPs também pudessem atuar conforme a reinterpretação de alguns princípios. Isto ocorre, porque para os Estados e organizações internacionais, incluindo as Nações Unidas, que passaram a contratar as EMSPs, a presença armada no campo humanitário pode ser necessária quando a finalidade é garantir a não violação dos direitos humanos em áreas fragilizadas do planeta.

O discurso dos direitos humanos tem sido evocado por muitas organizações para reinterpretar os princípios tradicionais no campo humanitário. E isso se deu pela incompatibilidade entre a regra de soberania da ordem internacional e a realidade interna dos Estados em situação de instabilidade onde se podiam testemunhar graves violações dos direitos humanos, momento que muitas 
agências interpretavam como condição para suspensão dos princípios de neutralidade ou mesmo da imparcialidade ${ }^{32}$. Ao longo das décadas, a noção de direitos humanos também passaria a fazer parte de um quadro conceitual bem mais amplo, a saber, da segurança humana, cuja noção de humanidade é a mesma dos direitos humanos, mas que colocaria em xeque a relação com as diretrizes humanitárias tradicionais em termos de princípios. Essa foi uma articulação chave para a reorganização das políticas discursivas que constituem o campo humanitário no pós-Guerra Fria ${ }^{33}$.

A tensão entre Direito Internacional Humanitário e o regime de Direitos Humanos no que tange à soberania de Estado e ao imperativo moral ligado ao humanitarismo criou um campo de disputas com possibilidades institucionais ainda não pensadas até a década de 1980, dentre estas, a emergência de organizações humanitárias estatais ligadas à política externa ética dos Estados (Chandler, 2006), organizações humanitárias com agendas de desenvolvimento (Duffield, 2002), a descaracterização do espaço humanitário como exclusivamente desmilitarizado (Cockayne, 2006b), e o estabelecimento de Empresas Militares Privadas com agendas humanitárias ao longo do globo (Spearin, 2008). A relação entre a ressignificação dos princípios e o surgimento de novos atores no campo humanitário expressaria a constituição ontológica do humanitarismo como uma verdadeira tensão de discursos. Essa tensão de discursos é dominada por duas lógicas: a lógica da diferença e a lógica da equivalência.

A lógica da diferença é uma ordem conceitual onde os discursos separam as identidades por suas naturezas diferenciais e, sob forma de demandas, tornam-se autônomos quando cada demanda consegue ser diferencialmente representável dentro do sistema a qual se localizam. Neste caso, a maior parte das demandas encontrar-se-iam satisfeitas dentro do sistema e, deste modo, não necessitariam entrar em equivalência com outras demandas. Assim, na lógica diferencial, segundo Laclau (2005, p. 103-4), não há formação interna de uma cadeia de equivalência ${ }^{34}$. A lógica da equivalência, como já mencionado, trata-se de uma

\footnotetext{
${ }^{32}$ Vale ressaltar que quando cito os princípios da neutralidade e imparcialidade me refiro ao discurso construído sobre estes conceitos e não à pressuposição de que algum dia estes discursos foram possíveis na prática.

${ }^{33}$ Essa conexão é apresentada no capítulo 4.

${ }^{34}$ Embora seja quase impossível que um sistema se mantenha totalmente numa configuração da lógica diferencial, esta seria a configuração das sociedades homogêneas, uma vez que não
} 
configuração no social onde ocorre uma renúncia parcial das particularidades, destacando-se o que todas as particularidades têm tendencialmente em comum, algo que vai se tornar o conteúdo "universal" das diferentes entidades da cadeia de equivalência no campo (Laclau, 2005). Aqui é necessário, contudo, significar a totalidade da cadeia e não as demandas parciais e, por isso, uma das demandas parciais acaba se tornando dominante à medida que outras demandas são frustradas. A demanda parcial que se torna dominante assim se faz pelo caráter distintivo que toma seu símbolo ao circular pela sociedade. Um esquema heurístico pode ser obervado na figura 01 .

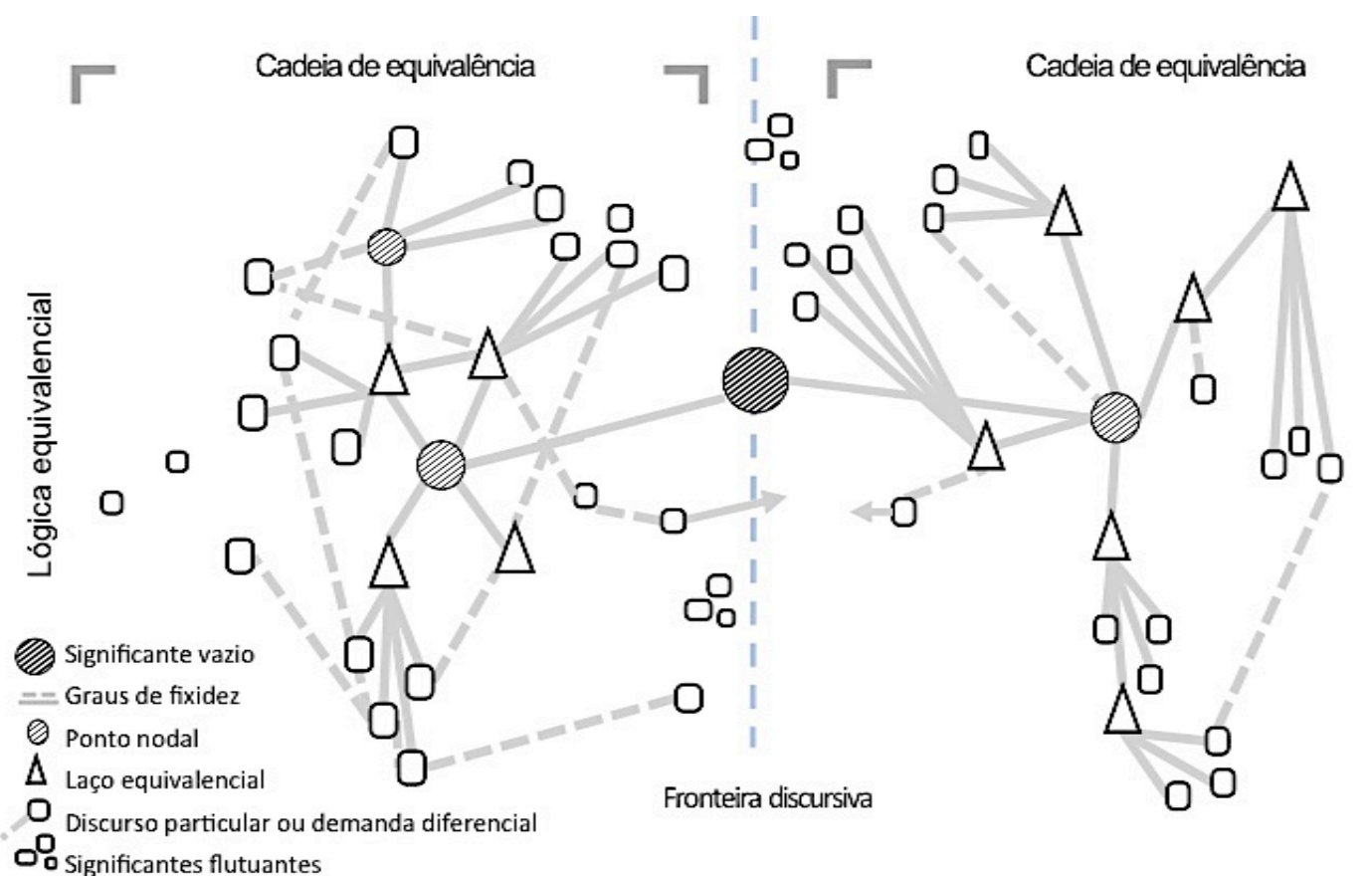

Figura 01: Possibilidade discursiva num campo de duas lógicas equivalenciais

Num vocabulário Laclauniano, poderíamos, portanto, dizer que a identidade humanitária pode ser vista como tensionada, por um lado, (i) pela lógica da diferença que expressa as particularidades de cada demanda no campo humanitário e diferencia os discursos dos humanitários tradicionalistas daqueles que não mais se apegam aos princípios clássicos dos primeiros e, por outro, (ii) pela lógica da equivalência que une uma série de organizações com diferentes agendas pela similitude com que se apropriam de algumas narrativas (tais como 
os direitos humanos e a segurança humana) como norma prioritária para ação ou intervenção humanitária.

A figura do humanitário que abrange amplas categorias que vão desde o cuidador e médico ao soldado privado não é meramente o resultado de uma posição ideológica, mas de uma relação de demandas e interesses entre diferentes posicionamentos políticos e sobredeterminações ${ }^{35}$. Pode-se, a partir de Laclau e Mouffe (1987), afirmar que o humanitário é uma concepção que demonstra o caráter não essencialista da relação entre protetor e protegido e que revela o caráter precário das identidades uma vez que é impossível fixar o sentido dos elementos de forma literal e definitiva.

A neutralização do cuidador humanitário, do soldado ferido e do indivíduo civil nasceu como um movimento de ressignificação de conceitos e normas que dariam azo à formação de novas posições de sujeito no humanitarismo contemporâneo. O passo que antecedeu este movimento pode ser encontrado numa noção negativa de guerra, isto é, de que a guerra nunca seria extinta por se tratar de uma instituição que não tem solução e, portanto, só restaria pôr em prática o exercício de fazer algo por aqueles que dela são alvos. Dessa ideia pode ter surgido o ativismo de Henry Dunant ${ }^{36}$, advindo de um questionamento que se tornaria uma luta racional e pragmática e que não visaria contestar os instrumentos de poder dos estados por meio de um pacifismo dito improdutivo, mas em circunscrever normativamente um conjunto de possibilidades de tornar a violência nefasta e inevitável o menos desumana possível.

O chamado interior de Henry Dunant para mitigar os efeitos destrutivos da guerra parecia não visar à origem e não carregava um projeto propriamente reformista (Leebaw, 2007; Forsythe, 2005), mas se direcionava aos alvejados, aqueles que, impotentes pelas dores de suas dilacerações não mais ameaçavam qualquer parte. A fundação do Comitê Internacional da Cruz Vermelha (CICV) a partir de Dunant refletiu isso e tem sido considerada por muitos um passo primordial na modificação da estrutura normativa do sistema em assuntos de guerra (cf. Finnemore, 1996). Deste contexto viria ser codificada a primeira da já

\footnotetext{
${ }^{35}$ Para Laclau \& Mouffe (1987), influenciados por Althusser, não há nada no social que já não esteja sobredeterminado. A sobredeterminação é o caráter simbólico das relações sociais e não tem uma literalidade única, pois os indivíduos não podem ser separados em essências e aparências, já nascem sobredeterminados no social (p. 163-164).

${ }^{36}$ Sua biografia e as recordações da Batalha de Solferino estão bem detalhadas em Dunant (1986)
} 
mencionada sequência de normas que compõem as convenções de Genebra referente à melhoria da situação dos soldados feridos e doentes.

Essa inovação normativa na figura do ser neutro implicaria uma dubiedade para a figura do soldado com fortes consequências institucionais. O soldado é o ser que representa o Estado, mas ao mesmo tempo não se constitui como tal, pois sua situação de emergência, de limite, permite-lhe deixar de representá-lo. Sua impotência o liberta virtualmente de quem ele é. Crenças, ideologias e simbologias são, em parte, suspensas, e o que passa a importar é o zoé aristotélico, a constituição mais elementar enquanto ser orgânico e a norma humanitária que o abraça e preserva sua humanidade vulnerável. A vida é nua no sentido agambínico (cf. Agamben, 2002), mas também é artificialmente constituída como tal, pois assim como o ferido não abandona as sobreposições que constituem sua condição de sujeito vivente, a norma que vincula seu corpo, enquanto coisa, à norma humanitária, enquanto discurso, é igualmente uma construção artificial.

Essa construção, contudo, não é infragmentável, assim como qualquer discurso não o é. É passível de ter seus significados disputados no social, algo que aparece com muita nitidez a partir do final do século XX, seja pela influência midiática mediante maiores oportunidades de difusão de imagens de catástrofes, seja pela intensificação da globalização.

Como já mencionado, até a metade do século XIX a figura do combatente ferido (posteriormente de qualquer vítima de guerra) era traduzida por um discurso de representatividade embebido em uma racionalidade influenciada por direitos associados à lógica de soberania do Estado. A totalidade, o maior escopo levado em consideração no imaginário politico até então, era o sistema de Estados. E enquanto unidade de interesse, somente se concebia a categorização de um indivíduo por meio de sua relação com o Estado-nação - primariamente como cidadão - ou como estrangeiro (Finnermore, 1996, p. 71). Entretanto, a emergência da norma humanitária viria ter um caráter duplamente desestabilizador, não apenas por desafiar o Estado como a única parte reconhecida do todo europeu, mas também o próprio sistema de Estados enquanto totalidade que, para dar conta do discurso da individualidade, expande-se do cidadão para toda a humanidade. $\mathrm{O}$ não hostis ${ }^{37}$ agora é o humano.

\footnotetext{
${ }^{37}$ Aquele que não altera o equilíbrio de forças no campo de guerra.
} 
O discurso humanitário abre um campo de possibilidades articulatórias que apresenta os indivíduos com um status e valor não mais dependente de sua relação com as entidades soberanas. Ao afirmarem que os seres humanos têm direitos e valores simplesmente em virtude de sua humanidade, os humanitários acabaram por criar um conjunto de alegações normativas que competiriam com as aquelas feitas pelos próprios Estados (Finnermore, 1996, p. 71).

Todavia, a fundação do humanitarismo moderno posiciona-se paradoxalmente citando as próprias normas que estruturam o sistema internacional. O monopólio do uso legítimo da força não é questionado por nenhuma das convenções de Genebra, a noção de comunidades políticas nacionais como formadoras de um todo social (nações) são reafirmadas como as partes signatárias e ratificadoras dos tratados, a guerra prossegue como prática normal e legítima entre os Estados, bem como a diferenciação entre aqueles que merecem o status de protegido e aqueles excluídos da proteção (apátridas, imigrantes não documentados, "terroristas", prisioneiros de Guantánamo, etc.).

O paradoxo sob o qual se deitará as ideias de protetor e protegido ao longo do tempo não refletirá simplesmente a complexificação do conceito de humanitarismo moderno, mas igualmente uma disputa por seu significado num campo de forças cuja fronteira nunca é totalmente fechada. Essa cadeia de possibilidades está aberta na linguagem humanitária por meio de práticas articulatórias.

Dois momentos passaram a convergir a partir da Convenção de Genebra de 1864: por um lado, a instância pública, i.e., os combatentes que são a encarnação da ameaça ou do inimigo público e, por outro, a instantânea privada, i.e., a neutralização de todas as vítimas de guerra pela norma humanitária. A desmilitarização da figura do soldado, cuja condição de agente está borrada devido a sua impotência, passa a construir para o soldado ferido uma categoria tal qual ao do humanitário-cuidador. Ambos, na condição de neutros, não são representantes das partes beligerantes e nem ameaçam a estas. São diferentes posições de sujeito e de poder, mas unificados por uma terceira categoria que torna possível a equivalência de ambos. $\mathrm{O}$ inimigo público perde seu caráter ameaçador e o socorrista perde sua cidadania em favor de identidades semelhantes no campo humanitário: são neutros. Mas são igualmente imparciais, pois não se pode escolher discriminatoriamente por quem será socorrido ou a 
quem irá socorrer, e não se pode negar um imperativo, o respeito por parte do humanitário de um princípio que primariamente para li o designou.

Os indivíduos nesta circunscrição são desmilitarizados, pois no campo muitas vezes designado de "espaço humanitário" são todos artificialmente civis sem que armas ou patentes tenham qualquer serventia para os propósitos em questão. Desta maneira se construiu a quadra mais importante do espaço humanitário tradicional: neutralidade, humanidade, imparcialidade e independência, arduamente defendidas pelo CICV. Entretanto, esta não seria uma construção normativa forte o suficiente para se manter frente às mudanças borbulhantes no campo social. Assim como as fronteiras que conformam a identidade dos sujeitos e das instituições são frágeis ou, no máximo, porosas, também são os significantes presentes no discurso humanitário.

Algumas destas mudanças no campo social podem ser encontradas na formação de novas formas de poder, na emergência de novos vocabulários na prática de guerra e da proteção, nas novas oportunidades de expansão de velhas economias discursivas como a lógica da racionalidade onde se privilegia a precisão, qualificação, quantificação e especialização, ou mediante novas oportunidades tecnológicas, políticas e de mercado. Tais eventos podem estar configurando determinados conjuntos de discursos e práticas que flutuam entre os diversos espaços e atores envolvidos na arte do humanitarismo, e as EMSPs são parte constitutivas desses fenômenos. 


\section{A expansão do humanitarismo moderno e de seus agentes}

\subsection{Compreensão histórica da prática humanitária}

No capítulo anterior, observou-se que a ação humanitária surgiu a partir do contexto do conflito armado e foi legitimada sob o direito internacional humanitário na segunda metade do século XIX. Contudo, apesar de sua origem poder ser remontada a este ou a períodos da história muito anteriores, a compreensão das práticas humanitárias modernas pareceria mais esclarecedora se recorrêssemos ao momento em que as práticas caritativas e filantrópicas passaram progressivamente da esfera religiosa para a esfera secular sob o controle do Estado na Europa, governança esta, que coincide com a própria formação do sistema de estados europeus (Esteves, 2010a). Aqui o foco está, no entanto, no recorte do período da criação do Comitê Internacional da Cruz Vermelha fomentado por Henri Dunant e da formalização do Direito Internacional Humanitário quando a prática humanitária foi considerada uma condição indispensável em situações de guerra. Essa prática tornou-se tanto um valor defendido por agentes que enfrentaram os Estados europeus a fim de humanizar as guerras (Finnemore, 1996 apud Esteves, 2010a) ou, porque a prática humanitária seria coerente com os interesses dos Estados europeus em lidar com as consequências não intencionais de suas estratégias ao mesmo tempo em que se obteria apoio público para suas campanhas (Forsythe, 2005; Hoffman \& Weiss, 2006 apud Esteves, 2010a).

A ação humanitária tem, pois, sofrido uma série de ampliações em seus conceitos ao longo de mais de um século e, a partir dos anos 1990, adquiriria novas interpretações quanto à definição dos princípios que regem sua prática, tais como a neutralidade, humanidade e imparcialidade ou outros como independência e proteção.

A diversificação dos atores envolvidos no campo humanitário ao longo de mais de um século levanta questões relacionadas à legitimidade normalmente 
esperada dos atores nesta arena. Como exposto no capítulo 1, o humanitarismo antes comportava a figura do neutro, concebido historicamente como a não participação de um Estado nas hostilidades, i.e., a figura não-hostil durante os conflitos que se limitava ao cuidador e ao combatente ferido. Posteriormente essa neutralidade seria reinterpretada de modo a comportar atores militares privados, tais como as EMSPs, como observado nos documentos já mencionados. Essa contradição é compreendida como um efeito das mudanças contextuais do curso histórico das práticas emergenciais e das possibilidades discursivas delas emergentes. Faz-se necessário, portanto, desenvolver uma discussão sobre alguns dos discursos envolvidos na prática humanitária que viriam a possibilitar e legitimar a presença militar privada no campo humanitário.

Um desses discursos é a própria prática da guerra (e suas regras resultantes), que, seja baseada na noção de guerra justa, em doutrinas inspiradas no direito privado ou em noções mais tardias de direito da sociedade internacional (europeia), se deparava cada vez mais com oportunidades tecnológicas que exacerbaram visualmente a escala de seus efeitos. O Direito Internacional Humanitário formalizado no século XX que emergiu no século anterior como uma forma de mitigar os efeitos destrutivos dos conflitos refletiu isso e teve como um dos precedentes modernos um conjunto de regras estipuladas para estabelecer limites às práticas e aos instrumentos de guerra.

O primeiro precedente teria surgido no contexto da Guerra da Criméia da qual resultou a Declaração de Paris de 1856 sobre os limites dos beligerantes em conflito marítimo (Kennedy, 2004). Outras origens podem ser encontradas nos esforços aplicados à codificação de regras mais abrangentes como no caso da Declaração de São Petersburgo de 1868 e nas Convenções de Genebra entre 1864 e 1949 e Haia em 1899 e 1907. O Código Lieber, mencionado no capítulo anterior, iria também influenciar os modelos dos manuais de vários exércitos europeus nas décadas que se seguiram, como, por exemplo, Holanda, França, Sérvia, Espanha, Portugal (Mcfarlane \& Khong, 2006), e a reformulação do código de Alexandre II, documento este que seria uma das bases para as Convenções de Haia (Kennedy, 2004, p. 239).

A partir desse contexto, o humanitarismo moderno, ainda que nascido do contexto da prática do conflito interestatal, seria alvo de expansões enquanto um conceito e seria ressignificado ao longo de várias décadas mediante os desafios 
encontrados pelos agentes humanitários, seja no aumento do número de mortos e combatentes feridos, seja por efeitos mais abrangentes como fome, desastres naturais, doenças e conflitos civis que provocavam sérios efeitos sobre as pessoas internamente deslocadas (IDPs) ${ }^{38}$ e sobre os campos de refugiados. Este contexto daria forma ao fenômeno que começara a ser designado como "emergência complexa" por agências da ONU, algo conceituado como "um desastre humanitário relacionado a conflito que envolve um alto grau de deslocamento e desagregação social e, refletindo essa condição, requer uma resposta de ajuda de todo o sistema da comunidade internacional" (Weiss, 1999 apud Duffield, 2001, p.12; Fox, 2002). O termo ganharia evidência nos textos de agências privadas, públicas e na academia.

A ação humanitária antes sob o âmbito exclusivo das convenções de Genebra teve, pois, seu escopo avançado e a proteção das pessoas seria entendida como algo necessário, como direito, inclusive, em situações de conflito civil com a participação da comunidade internacional ${ }^{39}$. Sob a ótica aqui desenvolvida isso se faz possível, pois o direito enquanto discurso tem possibilidades infinitas de articulação. Como bem afirma Douzinas (2007)

A partir de uma perspectiva semiótica, os direitos não se referem a coisas ou a outras entidades materiais do mundo, mas são combinações puras de signos jurídicos e linguísticos, palavras e imagens, símbolos e fantasias. Nenhuma pessoa, coisa ou relação está, em princípio, fechada para a lógica dos direitos. Qualquer entidade aberta à substituição semiótica pode se tornar sujeito ou objeto de direitos; qualquer direito pode ser alargado a novas áreas e pessoas, ou, inversamente, retirados dos já existentes (p. 4).

Essa extensão evidencia a natureza artificial da concepção não apenas do direito, mas também de outros princípios que, mediante novas articulações, emanam de construções históricas e sociais temporalmente situadas. Assim como mencionado anteriormente, princípios como o da neutralidade que surgira de um debate da qual resultaram as leis que regem a guerra e a paz no direito internacional sofreram ressignificações devido a essa natureza própria dos discursos. Se neutralidade antes significava tudo aquilo que não era hostil durante um conflito (Hague V, 1907), i.e., combatentes doentes e feridos e indivíduos

\footnotetext{
${ }^{38}$ Do inglês Internal Displaced Persons.

39 Nos anos 2000, essa expansão se reflete no engajamento das agências humanitárias e de desenvolvimento a atuarem, inclusive, em espaços urbanos e em situações de não-guerra. Vide Muggah \& Savage (2012).
} 
privados, após a Guerra Fria o referente "não-hostil" se deslocaria para outra cadeia discursiva, a saber, do "humano" e da "humanidade" que borra a fronteira da narrativa anterior em favor de uma que possibilita abarcar novas posições de sujeito e identidades.

Vale ressaltar, no entanto, que a abertura desse referente à toda humanidade não é um elemento advindo exclusivamente das narrativas do século XX. Como se sabe, o campo discursivo é atravessado por uma pluralidade de demandas e posições políticas, mas o aprisionamento temporário de sentidos se dá pelo poder de fixação que um significante adquire, o que pode levá-lo a tornar-se hegemônico ou não. Embora certas narrativas estivessem por um momento fora do universo discursivo das práticas de guerra, outros elementos discursivos pairavam no ambiente social informando os agentes sociais das possibilidades interpretativas para mitigar o sofrimento nos campos de batalha para além das identidades dos Estados nacionais.

Para citar alguns exemplos, temos o discurso religioso da "humanidade comum" pelo exercício da compaixão, a "cultura de sensibilidade" espalhada pelas práticas caritativas do período iluminista e o "desenvolvimento da humanidade" como processo civilizatório. Estes podem ser considerados como discursos que juntos ou em tempos diferentes formariam o imaginário do humanitarismo moderno. Como ressalta Calhoun (2008), a antiga ideia de melhorar a condição humana remonta aos Cínicos e Estoicos com suas visões de cidadania mundial, mas na era moderna temos a fusão da ideia de mitigar o sofrimento humano causado pela guerra com outra mais geral de caridade, além das normas para a conduta honrosa da guerra. O pensamento humanitário passa a englobar, portanto, estas três clivagens - da humanidade comum, da cultura de sensibilidade e do desenvolvimento da humanidade - ao ter como seu objeto de proteção toda a humanidade não mais se limitando, pois, aos membros da própria comunidade ou nação ${ }^{40}$.

\footnotetext{
${ }^{40}$ Esteves (2010a) faz uma observação relevante a respeito da lógica da humanidade oitocentista mencionando duas ideias, de Calhoun (2008) e Elias (1994), que bem explicam o momento de transição do objeto do humanitarismo de então. Observa-se que "o humanitarismo tinha como objeto a humanidade, a despeito das diferenças supostamente raciais ou nacionais ... [e] até o início do século $X X$, o conceito de civilização, como um conceito dinâmico, que implicava a ideia de processo, terminava por mitigar as diferenças regionais e nacionais a bem da expansão de uma espécie de autoconsciência europeia ou ocidental representada, sobretudo, pela própria conduta individual" (p. 13)
} 
Há na era moderna dois processos paralelos e coincidentes: a abertura do universo humanitário para uma totalidade maior e a abertura do campo da neutralidade para um corpo mais extenso e paradoxal. No que tange ao escopo desta pesquisa, limito-me a indagar como esta "extensão" se deu no pós Guerra Fria de modo a acomodar, inclusive, a figura do soldado humanitário, não ferido, não enfermo e potencialmente hostil, algo que sob a noção clássica de humanitarismo seria um paradoxo para com as ideias de neutralidade e imparcialidade no campo.

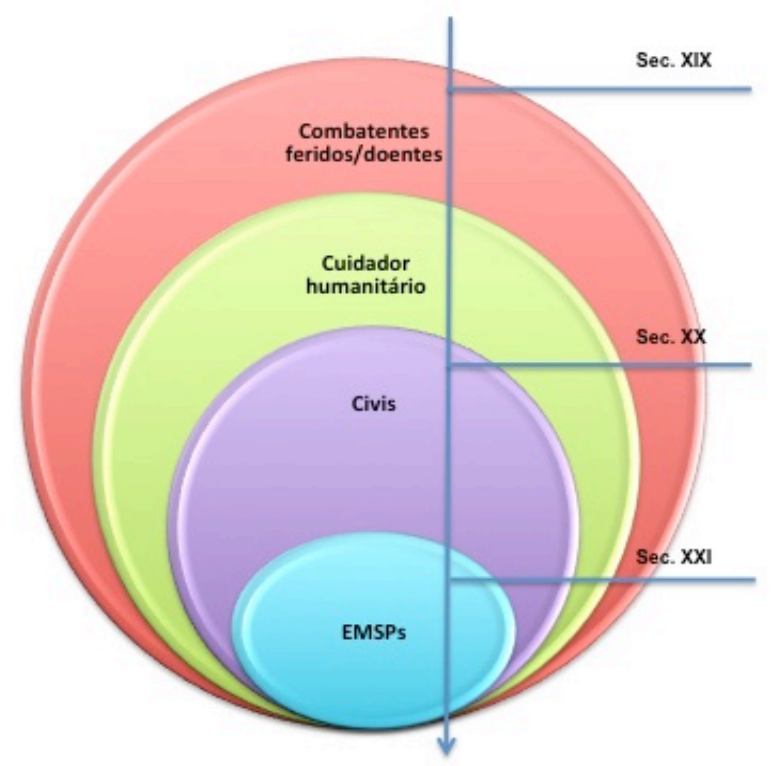

Figura 02: Expansão do discurso da neutralidade

Somente um processo de articulação de discursos torna possível a vinculação de certos elementos distintos numa mesma categoria. $\mathrm{O}$ fato de o lugar da neutralidade um dia ter sido correspondente ao lugar onde a identidade militar está temporariamente suspensa remete à indagação de quais processos teriam sobrepujado uma mudança. Seria este processo de abertura igualmente parte de um campo discursivo que abriria a possibilidade de existência do soldado humanitário? 
Se muitos analistas se perguntam sobre os processos históricos que permitiram a atuação de soldados privados - enquanto mercenários - em guerras e conflitos civis, o quanto mais não se devem perguntar quando presenciam estes últimos nas enfermarias provisórias de países destroçados pela guerra. Tenhamos em mente que as articulações que vieram constituir a possibilidade de um soldado privado ser humanitário teve como precedente a neutralização do soldado público quando este deixava se ser uma ameaça ao inimigo. A constituição do militar privado como um indivíduo humanitário, "neutro" é, de fato, inquietamente uma vez que, além de ser geralmente concebido como mercenário e não possuir a insígnia de um agente humanitário (como CICV, MSF, etc.), ele não se encontra em nenhuma condição de vulnerabilidade para que possa ser visto como um sujeito legitimamente situado em um espaço de assistência humanitária. Embora esta não seja uma relação causal ou facilmente detectável, há no processo discursivo do campo humanitário uma série de indícios que demonstram a permissividade para estas mudanças.

Um analista poderia perguntar por que este mesmo processo discursivo não poderia trabalhar para "humanitarização" de soldados públicos, membros de exércitos de países com recursos que enviam tropas inclusive para missões de paz aprovadas pelas Nações Unidas. A resposta é que nada impede que no campo discursivo humanitário isso já não esteja ocorrendo. Seja público ou privado, a retórica do soldado humanitário é tão passível de interpelações políticas quanto a noção de "democracia" o foi historicamente e os recursos de análise que se têm até o momento permitem que se façam importantes ponderações.

Embora o discurso humanitário esteja presente na retórica dos militares públicos, as missões empreendidas por militares de Estados nacionais fora do território nacional se caracterizam como "intervenções humanitárias" porquanto que a Carta das Nações Unidas, no artigo $2^{\circ}$, proíbe a ingerência nos assuntos internos de outros Estados. E mesmo quando se aplicam exceções, como no caso em que o Conselho de Segurança autoriza uma missão mediante reconhecimento de ameaça à paz e segurança internacionais, os militares públicos não são geralmente identificados como soldados humanitários, pois estão formalmente submetidos ao critério do DIH que separa as categorias militar e humanitária em identidade distintas quando regula a "proteção das pessoas que não participaram 
ou que deixaram de participar nas hostilidades" (CICV, 1998); assim o espaço humanitário teoricamente se suporia desmilitarizado e independente.

Ainda no viés mais tradicional, temos, por sua vez, a noção de "ação humanitária" que seria o fim dos agentes civis provedores de assistência e alívio, e não um meio de impedir uma ameaça à segurança e a paz internacional como o é para os militares. No entanto, existe uma série de discursos que desafiam a noção tradicional de ação humanitária principalmente quando o discurso dos Direitos Humanos são colocados como precedentes ou mesmo imperativos para tal atividade.

A emergência da norma internacional da "Responsabilidade de Proteger", por exemplo, visa transcender os casos em que as agências humanitárias não têm permissão de prover assistência quando um Estado não é capaz ou não está disposto a impedir as graves violações dos direitos humanos de seus cidadãos. O contexto para popularização da norma advinha da percepção de que a comunidade internacional não deveria ser mera expectadora das calamidades em curso nestes países. Além disso, o discurso de crítica ao well-fed dead levou muitas organizações a reformular suas políticas de atuação aspirando agora transformar as condições estruturais que colocavam as populações em situação de perigo (Barnett \& Weiss, 2008, p. 03).

Num momento em que o discurso intervencionista no meio interestatal já se fazia presente, e ganhava força principalmente depois de crises como a Guerra da Bósnia, o genocídio em Ruanda e a crise humanitária na Somália, a formação de uma lógica equivalencial em torno do significante intervenção ganharia forma na progressiva incorporação por parte de agências humanitárias das propostas da Comissão Internacional sobre Intervenção e Soberania Estatal (ICSS) ${ }^{41}$. Em consequência, muitas agências humanitárias começaram a se alinhar a Estados e a intervenções militares da ONU, abraçando os projetos posteriormente adjacentes de reconstrução pós-conflito, promoção da democracia e dos direitos humanos e

\footnotetext{
${ }^{41}$ Do inglês International Commission on Intervention and State Sovereignty (ICISS). A comissão foi criada no intuito de debater questões referentes à legalidade e à legitimidade das intervenções humanitárias; o trabalho de diálogo com diversas organizações governamentais, acadêmicos, ONGs, etc, . resultou na publicação do relatório "The Responsibility to Protect" (conhecido como $\mathrm{R} 2 \mathrm{P}$ ). Como afirma o relatório, os princípios básicos do R2P são: A: State sovereignty implies responsibility, and the primary responsibility for the protection of its people lies with the state itself; e B: Where a population is suffering serious harm, as a result of internal war, insurgency, repression or state failure, and the state in question is unwilling or unable to halt or avert it, the principle of non-intervention yields to the international responsibility to protect (ICSS, 2001, p. xi).
} 
reconstrução de Estado. As agências que preferiam não se envolver por seu compromisso com o princípio da independência eram muitas vezes acusadas de indiferença (Barnett, 2011, p. 4) e outras eram reticentes quanto ao potencial desafio à neutralidade e imparcialidade. A década de 1990 testemunhava, assim, uma expansão de compromissos de distintas naturezas e consequentemente dos atores privados que viriam competir por um espaço no então lucrativo empreendimento das organizações internacionais, governamentais e não governamentais.

Isso levaria ao questionamento moral se o compromisso dos humanitários seria procurar melhorar a condição humana e o bem-estar de toda a humanidade ou apenas procurariam aliviar o sofrimento de forma imparcial e neutra, ou ainda se seriam eles capazes de responder mais eficazmente às emergências humanitárias, crises aparentemente repentinas cujo conflito humano cria um “sofrimento extremamente desumano" (Calhoun, 2008).

A dificuldade de se fechar os conceitos "humanitário" e "ação humanitária" nos moldes dos princípios tradicionais propiciou uma oportunidade voraz para que o mercado pudesse fornecer uma terceira via que não é nem propriamente militar nem propriamente humanitária por meio da figura do "empreiteiro privado" e as EMSPs estariam dispostas a abraçar esta oportunidade. Uma mesma empresa poderia fornecer ajuda humanitária, proteção pessoal, segurança logística, proteção alimentar, capacitação de projetos para democracia, etc. O sujeito humanitário privado que também pode ser militar e não se submente às mesmas regras de um soldado público não seria mais contraditório para a lógica da ação humanitária, pois esta já havia se tornado generalista o suficiente para se fazer significar aquilo que visa proteger a humanidade de outrem, independente se a instituição que a conclama é uma agência ou corporação.

\subsection{A política da interpretação: humanitarismo, desenvolvimento e direitos humanos}

A (re)articulação da categoria do humanitário passou por períodos de inflexão que abriram um campo de disputa sobre seus sentidos. Nessa luta que ainda se mantém, dividiram-se pelo menos dois campos que se esforçam por se 
estabelecer como posições legítimas do sistema de ajuda humanitária: o humanitarismo tradicional e o novo humanitarismo. Como mencionado no capítulo 1, o primeiro prioriza o caráter emergencial e não político da ação humanitária, o segundo exclui o discurso da não politização da ação humanitária pelas consequências de longo prazo potencialmente negativas que o posicionamento tradicional pode provocar nas áreas afetadas. A representação da figura do soldado privado, dependendo do discurso sendo articulado, se encaixaria mais proximamente na segunda opção, muito embora as empresas militares privadas sequer sejam bem vistas aos olhos de muitos dos novos humanitários. As EMSPs não são facilmente compreendidas no registro da diferenciação entre público e privado e a expansão de suas funcionalidades até fronteiras antes impensáveis torna o apontamento das já instáveis identidades dos chamados "mercenários" uma tarefa nebulosa.

O processo histórico de reinvenção e reformulação das configurações que formaram o conceito de humanitarismo e de seu campo de ação ao longo de mais de um século não será esmiuçado em detalhes, mas é importante notar uma parte da complexa relação que o sistema de ajuda humanitária e o sistema de direitos humanos vieram desenvolver de modo paralelo, quando não transversal. $\mathrm{O}$ primeiro, advindo da regulação da guerra, e o segundo, que advém das demandas por direitos civis, vão ganhar um aspecto político que em alguns casos podem torná-los quase que indistinguíveis entre si. Como aponta Kennedy (2004), muitas vezes os humanitários mesmo que falem outras "línguas" vão usar o movimento de direitos humanos e seu vocabulário para chegar à porta antes de falar instrumentalmente ou em termos mais exclusivamente éticos (p. 05).

Segundo Douzinas (2007), o interesse no desenvolvimento e nos direitos humanos na área humanitária começou a crescer a partir dos anos 1970 e 1980 quando muitas ONGs adotaram estas preocupações ao promoverem políticas de apelo popular. Entretanto, após o fim da Guerra fria, a expansão do novo humanitarismo e sua lógica intervencionista levou muitas organizações a adotarem a politização da ajuda humanitária. Com efeito, havia que se encontrar uma forma de se conciliar duas prioridades conflitantes: manterem sua reputação de neutralidade e ao mesmo tempo manterem sua prioridade de levar desenvolvimento de longo prazo nas operações humanitárias. A saída, como menciona Douzinas (2007, p. 6), foi justificar as escolhas políticas por meio da 
"linguagem da moralidade e da ética em vez da política". Este teria sido o momento em que os "direitos humanos se tornariam o vocabulário preferido deste novo tipo de humanitarismo e muitas vezes são usados para disfarçar decisões complexas e controversas”. Além disso, desde as décadas de 1960 e 1970 já se testemunhava por parte da ONU o envolvimento com a promoção do Direito Internacional Humanitário como uma forma de lidar com os direitos humanos em conflitos armados e isso marcaria uma relação importante e cada vez maior entre o direito dos conflitos armados e direitos humanos (Herz, 2013).

Douzinas (2007) afirma, contudo, que a indefinição da linha divisória entre os direitos humanos e o humanitarismo não ficaria sem consequências e afetaria, inclusive, o Direito Internacional Humanitário uma vez que algumas políticas e regimes regulatórios foram traduzidos para a linguagem dos direitos, mas outros não; como observa:

The treatments of war prisoners, for example, has been largely displaced from the international law language of regulation and limits on state action into that of prisoners' rights. The effects of this change are evident in the American assertion that the Guatanamo Bay prisoners have no rights because they are evil murderers and a threat to western security. This is a clear violation of the Geneva Conventions but can be justified in the language of human rights. Human rights with their principles and counter-principles and their concern to create an equilibrium of entitlements are much easier to manipulate than clear proscriptions of state action (Douzinas, 2007, p. 6).

Como aponta Herz (2013), embora o discurso humanitário seja baseado majoritariamente em necessidades e o discurso dos direitos humanos seja baseado em direitos, na década de 1990 as necessidades e os direitos já não podiam ser totalmente separados e "a agência deduzida no conceito de direitos no que se refere a uma relação social é perdida na idéia do humano com necessidades” ( $p$. 14). O discurso dos direitos humanos acabaria como um dos motes contemporâneos para muitas agências internacionais, como os novos humanitários, uma vez que a junção discursiva levava as organizações a não mais manterem distinções funcionais. Herz (2013) aponta que, como resutado, as organizações humanitárias conectaram o alívio e proteção à agenda de direitos humanos e as organizações não-governamentais e intergovernamentais de direitos 
humanos tornaram-se cada vez mais envolvidas com o enfrentamento às violações do Direito Internacional Humanitário já que muitas vezes elas trabalhavam em áreas onde o conflito estava ocorrendo (Kalshoven \& Zegveld, 2001 apud Herz, 2013).

Da parte dos militares privados, as empresas de segurança privada que são contratadas por governos ou por organizações não governamentais, principalmente a partir dos 1990s, também teriam sua porção de confiança e apropriação destes discursos. Como isso é possível diz respeito à já mencionada impossibilidade de se fixar identidades e fechar totalmente um campo discursivo. As narrativas das EMSPs têm se aproximado significativamente do campo discursivo que integrara o grupo dos novos humanitários pela similitude de suas justificações. Doug Brooks, fundador e presidente emérito do International Stability Operations Association (ISOA), a maior associação de EMSPs do mundo, tem há alguns anos revelado como existe uma progressiva proximidade discursiva entre as EMSPs e a prática humanitária (dos novos humanitários), chegando ele mesmo, a se considerar um. Ao explicar a natureza dos serviços oferecidos por estas empresas, ele afirma que:

They [PSMCs] serve in peace and stability operations because we as humanitarians - want them there. They have been used in pretty much every recent conflict, including hundreds in support of the UN in Sierra Leone and some 80,000 in support of U.S. efforts in Vietnam. We need them: their skills and capabilities are irreplaceable. Problems that arise need to be addressed, accountability enhanced and IPOA has suggested how this can be done (...). Good oversight and accountability are good for good companies. But we can ignore the private sector's value to peace and stability operations only at great humanitarian peril (Brooks, 2007, p. 02, ênfase minha).

Alguns estudiosos discutem as especializações das EMSPs na assistência humanitária indagando justamente os desafios que uma identificação entre estes e os novos humanitários podem levantar. Como a proposta teórica aqui apresentada permite argumentar, a compreensão de que o campo discursivo tem infinitas possibilidades de articulação leva-nos a crer que tanto o fincamento de sentidos quanto o estabelecimento sólido das identidades dos atores humanitários jamais serão capazes de se fechar absolutamente às possibilidades de mudança. O 
discurso é produtivo e criativo e estas são condições importantes para o desafio de ordens que tentam se fazer ou já se mostram como hegemônicas.

No que tange à progressiva fissura interna entre os humanitários que precedeu o boom da indústria de segurança privada, pode ser encontrado um elemento de diferenciação em certos particularismos que possuem algumas organizações humanitárias. Temos, por exemplo, no caso do CICV diferenças significativas em comparação ao USAID (humanitária e de desenvolvimento) no diz respeito à noção defesa de um espaço (a)político. O CICV defende a possibilidade de um espaço humanitário apolítico devido ao compromisso com princípios como da imparcialidade no campo (Forsythe, 2005), mas outras organizações defendem que as consequências da ajuda humanitária politizam o campo e determinadas escolhas baseadas no alívio de curto prazo não teriam um compromisso ético de longo prazo com a promoção dos Direitos Humanos.

Temos aqui a associação de um mesmo elemento, a ética humanitária, a dois discursos opostos, um que evoca uma norma moral pela noção de humanidade como um todo, mas de caráter apenas emergencial, e outro que evoca uma noção consequencialista de humanidade atrelada à vítima de uma violação de um direito universal que transcenderia o caráter puramente emergencial.

David Chandler (2006) faz menção à transformação ocorrida no meio humanitário como um choque de princípios, e um verdadeiro movimento de politização. Ele descreve um processo de amalgamento entre duas linguagens de caráter universal uma vez que tem ocorrido a formação de um consenso entre organizações não governamentais internacionais, estrategistas de política externa e outras agências internacionais. Suas narrativas estariam se deslocando na direção de estabelecer um humanitarismo com base nos Direitos Humanos e que viria (re)definir as políticas humanitárias a partir dos anos 1990. Como prossegue Chandler,

The human rights NGOs, in conjunction with leading foreign policy strategists, have established a rights-based humanitarian consensus, the 'new humanitarianism', which has succeeded in redefining humanitarian policy. The universal principles, which defined the early humanitarian internationalists, are now widely criticised by their NGO successors as the language of universal humanitarianism has been reworked to pursue human rights ends. Today's humanitarians are concerned with long-term human rights outcomes rather than short-term humanitarian necessity (Chandler, 2006, p. 22). 
Essa configuração discursiva é justamente o que se tem denominado de "novo humanitarismo", que se afasta cada vez mais daqueles princípios tão caros aos ativistas humanitários de mais de cem anos atrás.

O ceticismo perante a possibilidade de se defender um projeto reformador de negação às guerras que, ao fim do século XIX prosseguiu forte no imaginário humanitário, não foi diferente ao cabo da Guerra Fria. O caráter emergencial continuou a ser o pano de fundo da ação humanitária e a razão de ser para os tradicionais, mas no caso dos novos humanitários não seria apenas a questão da emergência o elemento mais importante, mas a prevenção. Ou seja, se os relatórios indicarem que a má governança local, a pobreza, as condições precárias de higiene causam os conflitos que, por sua vez, causam o sofrimento e o deslocamento forçado de milhares de pessoas, logo, trabalhar sobre o alívio de curto prazo não cumprirá os propósitos da promoção dos direitos humanos.

Esta transformação institucional iria demonstrar uma vinculação cada vez mais próxima entre duas esferas que no passado costumavam ser bem mais distintas. Antes "ajuda humanitária" era distinguida de "ajuda ao desenvolvimento" justamente pelo caráter emergencial em que se configurava uma situação. Segundo o relatório que oficialmente faz a distinção entre ambas, o da Diretiva Estatística do Comitê de Assistência ao Desenvolvimento da OECD, emergência se define como:

An "emergency" is an urgent situation created by an abnormal event which a government cannot meet out of its own resources and which results in human suffering and/or loss of livestock. Such an emergency can result from (a) sudden natural or man-made disasters, or (b) food scarcity conditions arising from crop failure owing to drought, pests and diseases (DAC, 1998, p. 10; Fearon, 2008, p. 512).

Vemos mais adiante no relatório uma separação entre "relief food aid" e “developmental food aid" baseada no critério emergencial de um determinado país opondo-se, de um lado, "alívio humanitário" como resposta a uma emergência de causa 'repentina' e 'anormal', e de outro, "ajuda ao desenvolvimento" como uma tentativa de melhorar um determinado estado normal de coisas (Fearon, 2008, p. 52). Entretanto, a politização da ajuda humanitária por meio de sua complexificação vinculada aos direitos humanos tem 
fraturado mais profundamente a fronteira que separava discursivamente um campo neutro de outro comprometido com a política externa dos Estados.

Fiona Fox (2002) identifica essa fratura ao apontar duas posições no humanitarismo que, ao se basearem nos direitos humanos, tornam-se cada vez mais indissociáveis entre si. Se durante a Guerra Fria o alívio e desenvolvimento eram considerados distintos e discretos, agora existe tanto o "alívio desenvolvimentista" quanto o "humanitarismo meta-orientado" que são exemplos de tentativas de se "afastar da tradição rigorosa da Cruz Vermelha de prestar ajuda a todos com base nas necessidades humanas imediatas, em vez de considerar as consequências políticas de longo prazo" (p. 27). As agências humanitárias, afirma Barnett (2005, p. 732), estão demonstrando uma passagem de um dever baseado numa ética deontológica para uma ética consequencialista.

O discurso da impossibilidade de um espaço apolítico no trabalho humanitário, que antes parecia ser mais comum aos acadêmicos críticos da área das relações internacionais, tem igualmente pairado na retórica de distintas organizações. As agências com agendas de desenvolvimento, bebendo dos discursos da impossibilidade da não politização do campo, se apegaram ao imperativo humanitário que outrora existia apenas para solução de problemas emergenciais. A rearticulação do imperativo humanitário, baseado na norma da humanidade, saiu do campo emergencial e foi relativizado juntamente com o princípio da neutralidade. Em razão de testemunhos de catástrofes insilenciáveis o imperativo manifestou-se ao fim do século XX como um dever de ingerência e oportunidade de trabalho para atores comprometidos com a reconstrução de estados e implantação de novos sistemas políticos e jurídicos. A multidimensionalidade das operações de paz abraçava o campo humanitário e dava as boas vindas para figuras mais profissionais da área da segurança (cf. Duffield, 2002; Chandler, 2006; Esteves, 2010a). Isso viria refletir no aumento do número de contratos com o setor privado $\mathrm{e}$ abriria as portas para $\mathrm{o}$ estabelecimento de empresas militares privadas de diferentes espécies.

\subsection{A interpretação das políticas: humanitarismo enquanto um nome}

A propagação nos anos 1990s de princípios de gestão pública responsável e a confiança cada vez maior no conhecimento especializado, segundo Barnett 
(2005), dão azo a novos padrões de desenvolvimento que abrangem métodos científicos para calcular eficiência, profissionalismo, burocratização e melhoria de procedimentos. Esta lógica envolveu profundamente as organizações humanitárias num ambiente de necessidade crescente de demonstração de resultados de eficiência, formação de banco de dados e muitas vezes de competição sob a lógica de mercado. A adoção de procedimentos e padrões como a lógica de oferta e demanda tem levantado novas críticas ao setor humanitário devido a sua "mercantilização" e a algumas parcerias com corporações internacionais privadas (Vestergaard, 2011; Barnett, 2005; Weiss, 2013). A politização, mercantilização e institucionalização do setor humanitário têm levado a uma crise de legitimidade devido a uma série de contradições trazidas por estes processos e por sua natureza dupla e complexa: os humanitários representam os indivíduos em situação de necessidade, mas igualmente representam os doadores públicos locais (Vestergaard, 2011).

A história que se desenrola possui, no entanto, um elemento de crise organizacional para agências de ajuda humanitária em geral. As empresas militares ou de segurança privada desenvolvem progressivamente novas capacidades para se adequarem às novas demandas das operações multidimensionais semelhantes às práticas dos novos humanitários no campo ${ }^{42}$. As EMSPs em sua maioria eram contratadas por organizações de ajuda humanitária para servir como agentes de segurança (Van Brabant, 2002) devido a intimidações, sequestros, lesões e mortes e, ocasionalmente, podiam-se ver guardas privados armados na escolta de agentes de um determinado governo, de agentes da ONU ou trabalhando diretamente em operações de construção de Estado. Contudo, a apropriação das narrativas de ajuda humanitária e desenvolvimento abre uma gama de possibilidades de atuação para o setor privado.

O alívio desenvolvimentista e o humanitarismo meta-orientado que eram vistos como inovações nas agendas dos novos humanitários podem também ser

\footnotetext{
42 A denominação "multidimensional" se dá, porque envolvem trabalhos de várias naturezas, tais como a entrega de suprimentos humanitários, construção de instalações, implementação de desenvolvimento econômico e social sustentável, desminagem, implantação de sistemas jurídicos, e assim por diante. Antes, os envolvidos com tais práticas limitavam-se aos governos, as Nações Unidas e as agências não governamentais. O termo surgiu no contexto da publicação do então Secretário Geral da ONU Boutrous-Ghali do "An Agenda for Peace" de 1992, aparecendo em publicações como a de John Mackinlay \& Jarat Chopra em "Second Generation Multinational Operations. The Washington Quarterly, Summer 1992, p. 131-31".
} 
encontrados nas listas de várias empresas privadas contratadas para as operações de peacebuilding ${ }^{43}$. Um dos problemas que emerge, entretanto, é que o recurso a serviços privados de segurança para salvaguardar a vida e o trabalho dos humanitários é crítico para os princípios que muitos destes defendem.

Além dos problemas enfrentados perante as críticas sobre os meios e os fins para os quais o alívio é fornecido, os humanitários tradicionais enfrentam potenciais crises de legitimidade uma vez que, a manutenção dos princípios de neutralidade ou imparcialidade em seu local de trabalho é desafiada por um espaço cada vez mais militarizado. No caso dos novos humanitários que têm por bandeira a primazia do discurso de direitos humanos, uma potencial desestabilização identitária se faz possível à medida que o casamento do atendimento emergencial com práticas de desenvolvimento de longo prazo deixa de ser uma articulação predominante em sua área de argumentação; esse discurso também está presente na agenda de várias empresas de segurança privada que não apenas cooptam para si os elementos discursivos anteriores, mas trabalham sobre estes munidos da confiabilidade que vários atores internacionais depositam sobre sua capacidade de defesa e segurança. As empresas de segurança privada muitas vezes se denominam humanitárias e buscam manejar uma série de significados privilegiados no humanitarismo contemporâneo, tais como o alívio, o desenvolvimento e a segurança.

A fronteira diferencial que se constituiu a partir do fim da Guerra Fria entre o humanitarismo tradicional e o novo humanitarismo parece, pois, se fragilizar sem, no entanto, desaparecer - em razão do poder que o setor privado da indústria militar tem adquirido na política mundial. Porém há mais razões a se apontar por detrás deste fato.

\footnotetext{
43 Para conhecer algumas destas empresas de segurança privadas, visite os sites oficiais da Aegis, EODT e DynCorp International, respectivamente, http://www.aegisworld.com, http://www.eodt.com e http://www.dyn-intl.com/development.aspx.
} 


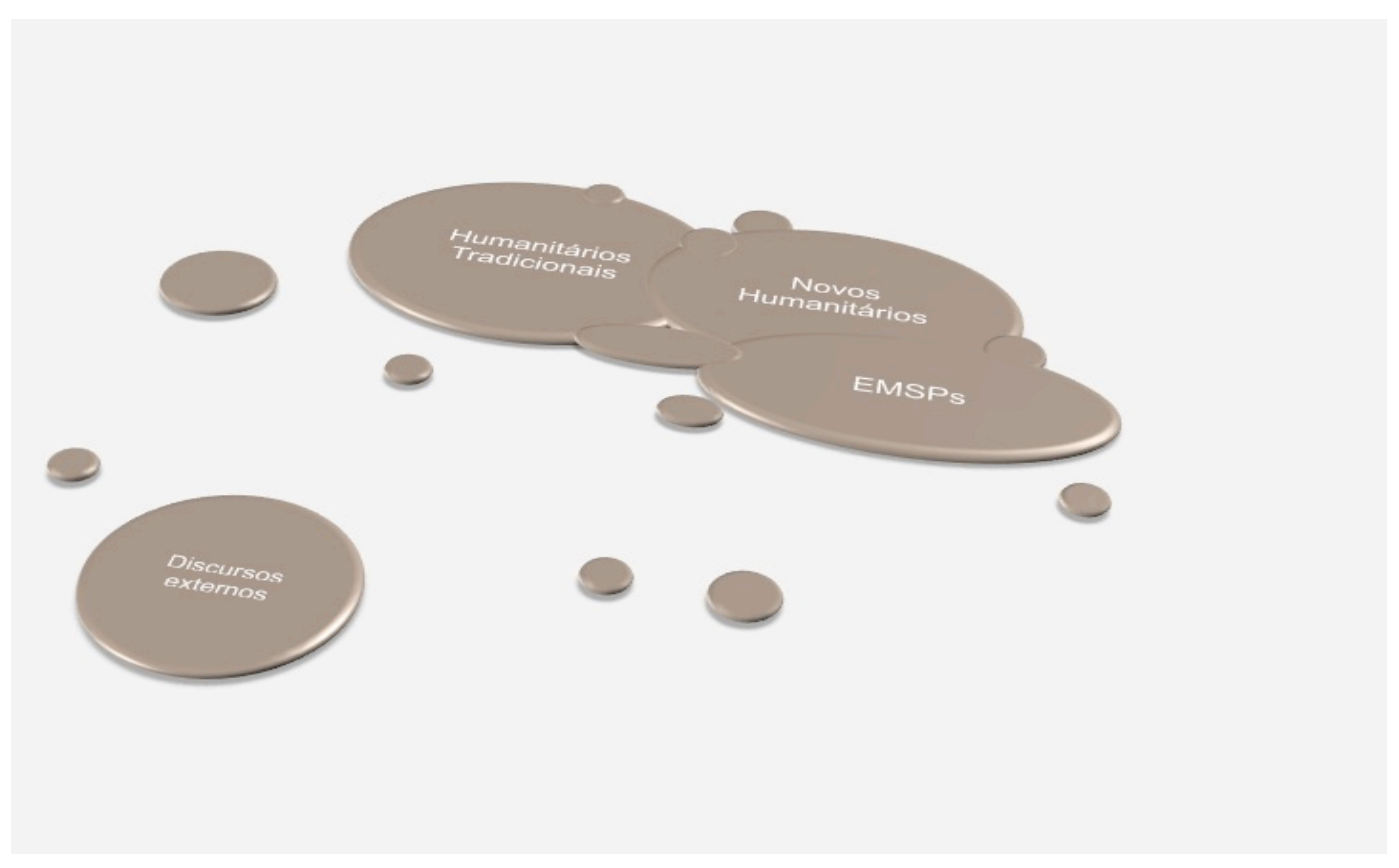

Figura 03: Três posições de sujeito no campo humanitário

A reprodução da insegurança no campo humanitário quando casada com a lógica de mercado e do cálculo racional enfraquece as fronteiras que formam os antagonismos no campo discursivo do humanitarismo. Em outras palavras, a reorganização das fronteiras discursivas apresenta uma oportunidade para a formação de uma cadeia equivalencial alternativa às demandas que são articuladas nos lados em disputa. A figura 03 faz referência a pelo menos três grandes posições de sujeito no campo humanitário cujas fronteiras não são fechadas: os humanitários tradicionais, os novos humanitários e as EMSPs.

As expansões paralelas da indústria de segurança privada nas últimas duas décadas e das narrativas de proteção e segurança deu espaço para muitas instituições privadas fornecerem serviços multidimensionais no campo humanitário e o manejo de discursos comuns entre novos humanitários e as EMSPs abriu uma oportunidade para que estes últimos se aproximassem discursivamente em posição de equivalência. De certo, que estas equivalências não são homogêneas e não há uma agenda específica que liste todas as demandas comuns entre novos humanitários e EMSPs, mas a impossibilidade de fechamento de suas cadeias discursivas pode permitir que qualquer momento de 
fragilidade interna ou estrutural seja passível de situar dois sujeitos opostos em um processo de "justaposição".

Há, entretanto, um pano de fundo teórico para esse fenômeno. Enquanto que a cadeia de equivalência formada por novos humanitários e EMSPs se dá por demandas gerais - tais como a primazia dos direitos humanos e da segurança humana sobre a soberania, o ideal de estabilização pelo desenvolvimento, a necessidade de métodos de contrainsurgência ou da Responsabilidade de Proteger - estas demandas não aparecem de modo exclusivo em um ou outro grupo, tampouco são discursos "puros" sem divisões internas. Por parte dos humanitários, as demandas por mais segurança e melhores resoluções em casos de graves emergências e violações dos direitos humanos eram particularismos advindos tantos de grupos movidos por quesitos deontológicos quanto de grupos meta-orientados. Por parte das EMSPs, no entanto, os particularismos são demandas majoritariamente meta-orientadas, concomitantes a interesses de mercado específicos.

Os processos diferenciais e equivalenciais dão formato ao contexto em que o humanitário começa a se mostrar como um significante tendencialmente vazio. Observe, porém que a “identidade humanitária” é uma posição de sujeito e, enquanto tal, é uma posição discursiva, e portanto, participa do carácter aberto de todo o discurso e não consegue estabelecer plenamente tais posições em um sistema fechado de diferenças. Não é, pois, propriamente da posição de sujeito do 'humanitário' ou do 'empreiteiro privado' que se originam as relações sociais do campo humanitário, mas dos discursos à eles adjacentes. O significante humanitário é fruto de um processo discursivo semelhante ao da noção de Homem e humanismo na moderninade. Laclau e Mouffe (1987) quando se referem a estes dois últimos significantes afirmam que enquanto discursos, estes são construções cujas características nada têm de algo inerente, e essa ausência de essência, ao contrário do que possa parecer, não nega sua validade histórica:

Por el contrario, de lo que se trata es de demostrar cómo el «Hombre» ha sido producido en los tiempos modernos; cómo el sujeto «humano» - es decir, el portador de una identidad humana sin distinciones - surge en ciertos discursos religiosos, se encarna en prácticas jurídicas y se construye diversamente en otras esferas. La comprensión de esa dispersión es la que nos puede hacer entender la fragilidad de los mismos valores «humanistas », la posibilidad de su 
perversión a través de su articulación equivalencial con otros valores y la limitación de los mismos a ciertas categorías de la población - la clase propietaria, por ejemplo, o la población masculina-. Lejos de considerar que el «Hombre» tiene el estatus de una esencia acordada, presumiblemente, por un don del cielo -, dicho análisis nos puede mostrar las condiciones históricas de su emergencia, y las razones presentes de su vulnerabilidad, permitiéndonos así luchar más eficazmente, y sin ilusiones, en defensa de los valores humanistas (Laclau \& Mouffe, 1987, p. 199)

A identidade humanitária é, pois, uma posição de sujeito discursivamente construída e seu caráter também abstrato não pressupõe uma articulação anterior positiva com outras posições de sujeito. Não se deve conceber o denominador comum expresso pelo símbolo humanitário como um traço positivo compartilhado por todos os elos da cadeia discursiva. As demandas dentro do campo compartilham de abstrações, mas não das mesmas características, uma vez que, "em uma relação equivalêncial, as demandas não compartilham de nada positivo, apenas o fato de que todas elas permanecem insatisfeitas. Por tanto existe uma negatividade específica inerente ao laço equivalencial” (Laclau, 2005, p.125).

Mas ao contrário do que advoga Laclau (1985), estas demandas não formam equivalências contra um regime opressor propriamente dito. $\mathrm{O}$ argumento que aqui se coloca é que esta nova cadeia equivalencial se forma contra um velho regime que tinha outros significantes privilegiados, tais como a soberania, uma velha ordem humanitária cujos paradigmas parecem desvanecer.

Os novos atores no campo geral da discursividade humanitária resistem à perpetuação desse velho regime para formar um novo que adapte o que acreditam ser as novas necessidades da política internacional, pela qual suas agendas acham mais convenientes. Um novo discurso humanitário de caráter hegemônico expande-se, portanto, unindo atores que institucionalmente e historicamente estavam situados em posições dispersas e muitas vezes conflitivas. Temos, por exemplo, o Estado, as organizações filantrópicas e o mercado; estes estão cada vez menos associados ao binário 'público' versus 'privado' e cada vez mais vinculados à moral desenvolvimentista liberal. Tem-se neste caso o acoplamento, ou se não, a cooptação de discursos rivais que não apenas brigavam sobre a definição do campo humanitário, mas igualmente por seu modus operandi. 
$\mathrm{Na}$ articulação sobre quem tem legitimidade no campo humanitário, o esfacelamento da fronteira entre público e privado bem como dos limites entre o militar e o civil permitem que novas relações de poder se manifestem. Na luta por eficiência e recursos para demonstração de excelência dos serviços, as EMSPs saem de uma cadeia discursiva que os identificava como seres de caráter puramente militar e entram no campo de disputa de caráter civil com uma denominação direta ou indiretamente humanitária. O significante humanitário que antes estava a flutuar entre diferentes posições de sujeito, é apropriado e algumas lutas são engajadas por atores que vão disputar por uma determinada estruturação da ordem discursiva que lhe estabeleça sentido. O sentido (vazio) que tem se estabelecido no campo atualmente dissipa os discursos antagônicos (ainda que impossível em sua totalidade) e o humanitário de natureza cívico-militar atinge um status hegemônico ${ }^{44}$. Sabemos que isso ocorre por meio de novas articulações discursivas que fragmentam certas fronteiras e lhes dão nova forma, mas esse processo é limitado por relações de poder que determinam o acesso de diferentes atores a discursos distintos (Vestergaard, 2011).

Assim como Laclau \& Mouffe (1987) afirmam que a divisão antagônica da sociedade supõe a presença de alguns significantes privilegiados que condensam em torno de si a significação de todo um campo antagônico, temos no caso do humanitarismo uma divisão antagônica condensando para si demandas particulares sobre a legitimação das figuras do protetor (militar, agente humanitário, soldado privado) e do protegido dentro de uma cadeia equivalencial humanitária $^{45}$. O vínculo ou laço equivalencial que tem condensado as particularidades em uma universalidade a partir dos anos 1990s é, sobretudo, o humanitarismo da promoção dos direitos humanos que agora está inserido no quadro da segurança humana.

A identidade dita humanitária do soldado privado condensa-se, então, em torno de discursos que se referem a esta cadeia equivalencial do novo humanitarismo como uma totalidade. A defesa da primazia dos direitos humanos e de significantes como 'segurança' e 'desenvolvimento' se articulam com os

\footnotetext{
44 Lembrando que o caráter hegemônico do significante não apaga suas fraturas internas e sua constestação.

${ }^{45} \mathrm{Na}$ condensação existe um denominador comum que encarna o vínculo equivalencial entre uma série de demandas particulares. Este provém da mesma série equivalencial e constitui ao mesmo tempo uma particularidade e uma universalidade (Laclau, 2005, p. 124).
} 
vocabulários da qualificação e eficiência no campo de trabalho e atendem às demandas dos doadores de que seus recursos sejam aplicados da melhor forma possível. Certificações de excelência, congressos, seminários, campanhas publicitárias, relatórios de campo, etc., são citações que enxertam a nova identidade institucional atribuída às empresas militares privadas que empreendem ação humanitária.

Os discursos básicos dos soldados humanitários articulam posições estruturais baseadas em histórias de proteção e progresso coletivo que acabam por criar representações em vista de legitimar suas posições de sujeito na indústria humanitária. A prática articulatória que une a figura heroica do soldado, protetor, salvador, empreendedor e eficiente funcionário casa-se, inclusive, com posições críticas presentes em toda sorte de textos que apontam para uma crise de gestão ou governabilidade do sistema de ajuda humanitária em geral. A percepção de uma crise da concepção clássica de humanitarismo fundada numa noção de ação não politizada e emergencial tem, portanto, formado novos processos de luta que acabam por dissolver as bases sobre as quais se fundamentava a figura - que se supunha - moralmente orientada e materialmente desinteressada do humanitário clássico.

A universalidade que informou o humanitarismo de outrora não foi desafiada apenas pelo discurso dos novos humanitários - pela recusa em potencialmente alimentarem economias de guerra, restabelecerem genocidas ou perpetuarem conflitos -, mas também pelas empresas de segurança privada que têm seu trabalho condicionado às possibilidades de lucro estabelecidas nos contratos.

Temos no campo discursivo do humanitarismo, portanto, um conjunto de significantes que ora flutuam, ora se estabelecem nas práticas de ajuda e alívio em conflitos e em desastres naturais ao redor do mundo. Entretanto, em meio à complexidade dos eventos históricos e ao surgimento de novas demandas até mesmo o discurso dos direitos humanos não pode se garantir como um constante laço equivalencial unificando a cadeia discursiva dos humanitários.

Como se vê na figura 03, há no campo discursivo humanitário, exterioridades, i.e., outras demandas, propostas e articulações que nem sempre conseguem formar um antagonismo forte o suficiente para se opor ou entrar em equivalência com outros discursos nesse campo. Deste modo, de acordo com 
Laclau \& Mouffe (1987, p. 193), quando se supõe que há uma exterioridade no campo geral da discursividade, a prática articulatória não formará sistemas de diferenças plenamente constituídos. Como já mencionado anteriormente, isso se dá pelo fato de o processo de fixação de significados nunca ser completa, pois a abertura do social resulta de um constante transbordamento do discurso pela infinitude do campo da discursividade. É esta dinâmica que permite que o conteúdo ou o sentido de um determinado nome se modifique ao longo do tempo para dar conta das possíveis contradições ou conflitos que possam emergir no campo. Os significantes que são usados para dar unidade à identidade do humanitário, jamais serão, portanto, elementos estáticos na cadeia discursiva.

Segundo Laclau (2005) quanto mais extensa for a relação equivalencial, mais vazio se torna o significante que unifica toda a cadeia. Assim, qualquer identidade humanitária precisará ser condensada em torno de alguns significantes (símbolos, palavras, imagens, práticas e instituições) que se referem à cadeia equivalencial como uma totalidade. Quanto mais ampla for a cadeia, menos ligadas estarão estes significantes às suas demandas particulares originais. Temos a "assistência humanitária" como um exemplo de discurso extenso, presente no portfólio das mais diversas categorias de associações (como o ISOA) e organizações envolvidas em missões emergenciais, da prática caritativa local às mais caras operações internacionais como da ONU ou regionais como da OTAN. Outro exemplo de discurso extenso é a noção de "segurança humana" cujo papel semântico não expressa um conteúdo positivo, mas funciona como denominação para um conjunto de direitos que nunca é pleno, pois sua plenitude é constitutivamente ausente ${ }^{46}$.

Para Laclau (2005), a unidade do conjunto equivalencial (uma que surge da vontade coletiva sobre a qual se cristalizam as equivalências particulares) depende inteiramente da produtividade social do nome. Para o autor, "Esa productividad deriva, exclusivamente, de la operación del nombre como significante puro, es decir, no expresando ninguna unidad conceptual que la precede" (Laclau, 2005, p. 139-140).

\footnotetext{
${ }^{46}$ A importância dos conceitos como Direitos Humanos e Segurança Humana como significantes que ganham diversos sentidos no contexto do pós-Guerra Fria está em suas capacidades de adquirirem a condição de pontos nodais. O papel da Segurança Humana como ponto nodal está desenvolvido no capítulo 4.
} 
A lógica comparativa aqui proposta tem por certa referência a ideia de Laclau, seguindo Žižek, a respeito do nome enquanto forma. O nome seria algo que se torna o fundamento da coisa. As operações significantes seriam os meios necessários para que o nome desempenhe seu papel. Os nomes, seja "humanitário", "humanidade”, "humanitarismo”, etc., são significantes que vão se sustentar de modo performático, descartando, pois a ideia de que existe um significado que seja o conteúdo verdadeiro ou primeiro de um discurso. A ausência de um significado pleno, contudo, não torna verdadeira a afirmativa de que tratamos de um "significante sem significado". Como coloca Laclau (2005),

La noción de un "significante sin significado" es, para comenzar, inadecuada: sólo podría significar "ruido", y como tal, estaría fuera del sistema de significación. Sin embargo, cuando hablamos de "significantes vacíos" queremos decir algo enteramente diferente: que existe un punto, dentro del sistema de significación que es constitutivamente irrepresentable; que, en ese sentido, permanece vacío, pero es un vacío que puede ser significado porque es un vacío dentro de la significación (p. 136, ênfase do autor).

Existem dois movimentos importantes na formação de um campo equivalencial que ajudam a formalizar sua identidade de campo. Primeiramente emerge do campo social um nome (ou nomes), que se converte progressivamente em um significante do que é heterogêneo em uma sociedade particular. Esse significante "vai exercer uma atração irresistível sobre qualquer demanda considerada como insatisfeita e, como tal, como excessiva e heterogênea com respeito ao marco simbólico existente" (p. 140). Subsequentemente, o nome vai começar a desempenhar um papel constitutivo dentro desse grupo, mas, enquanto um significante vazio, será incapaz de determinar que tipos de demandas entram na cadeia equivalencial (p. 140).

O exemplo oferecido por Laclau consiste na ideia de povo no campo social. O que dá unidade a um conjunto heterogêneo que se designa como "povo" são os nomes que vão constituí-lo enquanto objeto. A unidade do objeto é um efeito retroativo do ato de nomeá-lo. E o movimento inverso também ocorre: "nunca pueden controlar completamente cuáles son las demandas que encarnan y representan" (Laclau, 2005, p. 140). Assim, as identidades de grupo, as identidades institucionais, as identidades políticas, ou, como em seu exemplo, as identidades populares, "son siempre los sitios de tensión entre estos dos 
movimientos opuestos y del precario equilibrio que logran establecer entre ellos" (p. 140), o que resultará em uma ambiguidade ideológica necessária com claras consequências políticas.

Quando pensamos na ideia da identidade de povo enquanto uma função universal ${ }^{47}$ que dava sentido ao humanitarismo em diferentes períodos da história, vamos encontrar no século XIX a ideia de "civilização" como aquilo que dava unidade à ideia de Europa e era um discurso constitutivo de seu imaginário. Como consequência política, a ideia de "prática civilizada da guerra" era mais ou menos um elemento consensualmente compartilhado dentro dessa humanidade mais enxuta que era então a "totalidade" constituída por Estados europeus. A ideia de neutralidade fazia, pois, sentido no que tangia a tudo que não lhes imputasse nenhuma ameaça existencial no campo de batalha.

No final do século XX, essa função universal foi substituída por uma ideia mais expansiva de humanidade, deslocando-se cada vez mais da chave "cidadão nacional europeu" para uma ideia mais abrangente de totalidade. Começava a se compreender, por exemplo, uma noção de humanitarismo que abrangeria identidades antes fora do imaginário de civilidade europeu e, consequentemente, a condição humana enquanto coisa existencial permitiria que todo ferido em campo de batalha detivesse agora o direito de ser cuidado enquanto pessoa neutra e a figura do humanitário detinha do dever moral de cuidá-lo.

A função universal que sobressai no século XXI, no entanto, parece estar em formação. Pois existe o conflito entre duas narrativas que eram supostamente complementares. A humanidade como totalidade parecia complementar a ideia de direito humano, uma vez que nenhuma destas ideias tem fronteiras claras sobre o que lhes constitui. A humanidade do humanitarismo contemporâneo é ambígua no que tange a sua concomitante capacidade expansiva e restritiva. A ajuda humanitária é para todos os neutros dessa humanidade, mas as agendas humanitárias na prática de campo precisam restringir essa humanidade apenas àqueles que se enquadram nas exigências de neutralidade dos doadores.

A cadeia de equivalência do humanitarismo contemporâneo, que ora parece formada ora parece em construção, reflete, pois, os mesmos movimentos que

\footnotetext{
${ }^{47}$ A função universal sempre se refere a um discurso que dá unidade a uma totalidade qualquer. Não se trata de um "universal" no sentido mais amplo do termo, mas de um elemento presente dentro de um todo discursivo, que pode ser desde um pequeno grupo familiar a um movimento político global.
} 
fazem parte da formação dos campos discursivos. Observemos que na formação dos discursos é relevante que se compreenda a impossibilidade de uma totalidade ser completamente fechada por ser sempre passível à contingência.

Existe, no entanto, uma condição de inteligibilidade importante nos processos discursivos uma vez que o eterno fluxo de sentidos dentro de um campo discursivo deixaria de fora qualquer esforço humano para compreender os fenômenos sociais que o rodeiam. No fluxo de significantes, existe um ponto em que o significante pára o que de outro modo seria um eterno movimento de significação, de modo a se produzir uma ilusão necessária de que existe um significado fixo (Lacan, 1977, p. 303). O que para Lacan se chama Point de Capiton, para Laclau e Žižek vai se chamar Ponto Nodal.

A concepção de ponto nodal de Laclau (2005, p. 134) vai nos ajudar a compreender os processos linguísticos envolvidos na ordem discursiva do humanitarismo, pois se trata de um ponto de estruturação em torno do qual o significado é estabelecido ${ }^{48}$. Um ponto nodal age como um centro discursivo que tende a exercer um efeito totalizador sobre posições contíguas tal que estas perdem parcialmente seu caráter flutuante e tornam-se partes da rede estruturada de significados (Žižek, 1989, p. 87 apud Smith, 1998). Trata-se de um nome que unifica um campo qualquer para constituir sua identidade. "É a palavra à qual as 'coisas' mesmas se referem para reconhecerem-se a si mesmas em sua unidade" (Žižek, 1989 apud Laclau, 2005, p. 134).

Se pensarmos na função universal do humanitarismo dos séculos XIX e XX como pontos nodais teremos as noções, respectivamente, de civilização e humanidade como estruturadas em torno de significados que as privilegiaram por muitos anos como uma totalidade desejável, ainda que plenamente impossível nos moldes do pensamento europeu ${ }^{49}$. A primazia de uma ou outra totalidade mostrou-se, no entanto, como temporária - algo que se espera em todo espaço fraturado de um campo social. O status privilegiado da posição de determinado

\footnotetext{
${ }^{48}$ Laclau (2005) também refere Ponto Nodal como o que seria o "objeto a" de Lacan ou a unidade de uma formação discursiva (p. 134).

${ }^{49}$ Observe que, em contraste com Barnett (2011), considero que a ideia de "humanidade" foi o significante com função de ponto nodal do humanitarismo entre o Pós-Guerra e o fim da Guerra Fria e não a "soberania", como a partir de seu texto poderia se presumir, pois a soberania segundo nossa abordagem teórica seria o ponto nodal do campo discursivo das relações internacionais daquele período, maior em extensão do que o campo humanitário.
} 
ponto nodal, como civilização, humanidade, etc., pode ser, portanto, sempre interrompido por novas articulações.

No século XXI, o discurso dos Direitos Humanos tem se fortalecido enquanto laço equivalencial a ponto de parecer incontestável em vários contextos sociais, algo que muitas vezes lhe caracteriza também como um ponto nodal. A articulação de elementos advindos da promoção dos direitos humanos, do discurso do novo humanitarismo, de movimentos securitizantes e desenvolvimentistas juntamente do aumento no número de contratos com empresas militares privadas no campo humanitário desafiam mais uma vez o significado do laço equivalencial que por algum tempo parecia constituir a figura do humanitário clássico. $\mathrm{O}$ todo agora é atravessado por possíveis condicionalidades do alívio e de ajuda imputadas aos indivíduos em situação de necessidade. Se antes a norma humanitária passou por um momento em que tinha por interesse o corpo a ser salvo, i.e., o indivíduo desprovido de suas particularidades, agora essas particularidades são potencialmente definidoras de seu caráter de protegido e de sua inclusão do campo humanitário. Como observou Pierre Krähenbühl, diretor de operações do CICV:

(...) because what we saw in Afghanistan in certain cases, the collaboration of people, Afghans in different villages where the army said "in exchange for information on our enemy and his whereabouts you will receive humanitarian assistance", so humanitarian assistance becomes part of the counterinsurgency strategy. That makes the work of humanitarians very dangerous because it associates it with political and military strategies, that's what we see an absurd groundline (Access to the Danger Zone, 2012).

O humanitarismo quando vinculado aos Direitos Humanos permite relativizar o princípio da neutralidade em função da universalidade que o imperativo humanitário carrega consigo, mas os Direitos Humanos também permitem a relativização de sua própria universalidade ao condicionarem o caráter emergencial do humanitarismo às situações em que a política externa de Estados e a agenda política dos doadores delimitam o escopo da assistência humanitária. Vemos que o princípio da humanidade tanto do humanitarismo quanto dos Direitos Humanos se ressignifica, portanto, dentro de uma dimensão considerada por humanitários tradicionais como cada vez menos imparcial. 
O estabelecimento da figura do soldado privado humanitário está submerso neste campo de ambiguidades e dele se alimenta. $\mathrm{O}$ aumento do envolvimento destes e dos bilhões de dólares que são despendidos para sua manutenção seja na simples escolta de comida ou em operações de intervenção, demonstra que a relação entre princípios e posições legítimas de sujeito no campo do humanitarismo é uma relação criativa e capaz de produzir possibilidades de articulação das mais diversas.

A noção de humanidade que aparece nesse contexto carece, portanto, de um significado único e vai desde uma noção orgânica de corpo que deve ser preservado a uma noção de proteção condicional devido à ligação da prática humanitária a retornos financeiros e comerciais. Esta condicionalidade se configura como um elemento que desafia a concepção de imperativo humanitário e a ideia de totalidade a partir dela formado. Mais uma vez as fronteiras do campo discursivo que haviam sido fixadas, embora nunca de forma completa no sistema de ajuda humanitária, se veem atravessadas por novas articulações. Podemos até indagar qual significado se conformará como hegemônico no decorrer do curso histórico do humanitarismo no século XXI. Entretanto, trata-se de um fenômeno melhor compreendido ex post facto. Por ser dinâmico, é possível vislumbrar certas possibilidades da formação de determinadas cadeias discursivas no debate sobre ajuda humanitária, mas é apenas a posteriori que seremos capazes de identificá-las. Até aonde é possível estudar estes processos é um trabalho que me proponho a fazer na dissertação e que, por ora, foi exposto enquanto um processo teórico. 


\section{As EMSPs e sua agência}

\subsection{Compreensão histórica da prática militar privada}

Discutir a história das EMSPs é uma tarefa que geralmente se inicia com a referência mais comum e imediata à prática do mercenarismo, o que implica considerar que estas empresas não são necessariamente um fenômeno novo. Enquanto algumas referências à privatização da força militar podem ser encontradas em termos mais estritamente weberianos, ou seja, quando há uma separação entre forças de Estado e forças não-estatais no sistema moderno de Estados, outras referências podem preferir o contexto histórico privilegiando, por exemplo, a divisão entre público e privado ainda que em muitos contextos essa distinção seja pouco esclarecedora. As categorias de público e privado, muitas vezes, não podem ser precisamente delineadas em termos históricos para explicar a emergência dos soldados privados, pois em tempos antigos as configurações sociais e comerciais não eram estabelecidas da mesma forma como são as divisões contemporâneas da política e economia, o que pode implicar uma forma anacrônica de interpretação da história.

Mabee (2009), por exemplo, afirma que os sistemas sociais particulares no início da modernidade tinham arranjos diferentes dos do capitalismo avançado que exigiam "cada vez mais diferenciação entre o público e o privado, e possivelmente um estatismo em declínio" (p. 152). Já a diferenciação feita por Weber (2008) quando conceitua o Estado moderno não necessariamente fornece critérios claros que venham contribuir na diferenciação entre um militar público e um privado. Se o público serve ao Estado moderno, como definir então o sujeito militar privado que igualmente o serve por meio de um contrato? Este Estado para Weber (2008, p. 156) é "uma comunidade humana que, dentro de um território definido [...] (com sucesso) reivindica o monopólio da força legítima para si”. Mesmo se esse monopólio da força for bem sucedido, a legitimidade é tanto uma questão política quanto material. Da parte de Weber temos esclarecido que é o Estado que tem a palavra final na definição de legitimidade, mas é na questão 
política que se discute em que lado da divisão público/privado estariam as empresas militares privadas.

Alguns autores que têm criticado a definição de Weber afirmam que os exemplos históricos mostram que a monopolização estatal da violência é uma exceção, e não regra (Singer, 2001; Thompson, 1994), mas Weber (2008) parece responder a questão quando afirma que:

Force is not the normal or sole means available to the state. (...) In the past, many different associations, from the clan onward, have regarded force as a quite normal means. (...) The specific characteristic of the present is that the right to use physical force is only granted to any other associations or individuals to the extent that the state itself permits this (Weber, 2008, p. 156).

Curiosamente, ainda que o modelo de um exército de cidadãos contratados seja considerado historicamente novo parece haver uma convergência histórica quando comparado ao modelo dos soldados controlados pelo Estado, pois o que alguns autores se referem ao momento histórico do surgimento de exércitos privados coincide com os exércitos estatais. O debate histórico sempre permitirá discórdia sobre as origens e no caso da organização do serviço militar há discussões tão controversas quanto os momentos ligados ao "verdadeiro" surgimento do Estado moderno.

Para Singer (2003), antes do século XVI o conflito armado muitas vezes ocorria entre exércitos contratados por senhores de guerra locais ou regionais e grandes proprietários de terras. A figura do mercenário exercia seu comércio como qualquer outro artesão, trocando um conjunto especializado de habilidades e equipamentos por um preço. A troca dos mercenários para um exército de cidadãos foi motivada tanto pela ascensão do Estado-nação como modelo de organização política quanto por mudanças tecnológicas, vide os avanços particulares em armas de fogo que tornaram exércitos de massa compostos por um grande número de combatentes relativamente inexperientes mais eficazes do que pequenos grupos de combatentes altamente treinados. A manutenção de um exército permanente nacional também foi mais rentável do que a constante dissolução e conscrição de forças apenas quando necessárias (Singer, 2003; Dunning, 2010). 
No século XIX a utilização de mercenários tornou-se muito pequena. À medida que os Estados alteravam a condução da guerra aumentando os exércitos de cidadãos, também evitavam o uso de mercenários por prática ou por lei. Os Estados geralmente mais propensos a trocar exércitos mercenários por de cidadãos, segundo Avant (2000), eram os que tinham sido derrotados militarmente ou aqueles cuja coalizão de comando estivesse dividida ou fosse indiferente às reformas ligadas aos exércitos de cidadãos.

Muitos pesquisadores que ligam as origens das EMSPs aos tempos medievais consideram que estas empresas seriam os "mercenários dos tempos modernos" (Thompson, 1994; Singer, 2003) podendo ser possível encontrar seu arquétipo desde o século XIV. Para Thompson (1994) teria começado com a Guerra dos Cem Anos, mas Kinsey (2006) prefere considerar as raízes mercenárias no século $\mathrm{XI}^{50}$. As origens do mercenarismo enquanto mercantilização e internacionalização da violência são muito referidas à comercialização de guerra no norte da Itália no período medieval (Thompson, 1994; Kinsey, 2006), mas não há consenso sobre o caso. A própria palavra “internacionalização" para século XIV é problemática devido à ideia moderna de nação em termos de Estado-nação ${ }^{51}$. As cidades-estados do norte da Itália não eram Estados nos moldes modernos e a externalização de custos da guerra via mercantilização, na verdade, fortaleceram o poder de centralização em vez de enfraquecê-lo (Arrighi, 1994).

Além disso, a discussão entre os analistas lança dúvidas sobre se podemos tratar o mercenarismo antigo e contemporâneo da mesma forma, dado que as mudanças estruturais nas relações internacionais posteriores a eventos como, por exemplo, a Revolução Francesa ou a Guerra Fria foram muito significativas. As relações entre o mercenarismo, a força legítima, a ordem internacional e o estado de guerra e de paz colocam questões sobre a natureza do mercenarismo, especialmente nos casos em que os "mercenários modernos" engajam em atividade considerada humanitária.

\footnotetext{
${ }^{50}$ Kinsey (2006) erroneamente refere-se a Thompson que não menciona a data em seu livro de 1994.

${ }^{51}$ Mercenários são geralmente referidos como "soldados" estrangeiros que não têm ligações com uma causa de governo, só com o pagamento; no entanto, ao se dizer "internacionalização da força" implica-se que cada mercenário fazia parte de uma nação específica, quando a ideia de pertencimento que estes mercenários detinham poderia em nada se assemelhar ao modelo de Estado-nação moderno.
} 
O tratamento dado à figura do mercenário na contemporaneidade, por sua vez, instiga as EMSPs a se afastarem progressivamente do interesse geralmente "amoral" imputado ao corsário medieval cuja referência supostamente os precede. A tentativa de separar a prática "mercenária" das práticas das EMSPs também pode ser encontrada no discurso de outras entidades que não as empresas por si só. Encontramos em documentos como o Relatório da Comissão sobre os Direitos Humanos de 18 de janeiro de 2005 vários parágrafos que separam "mercenários" e "EMSPs" como dois fenômenos diferentes (CHR, 2005: §8b, §11; §54; §98, b). Em outros momentos, todavia, o documento adverte que as diferenças entre os dois tornaram-se turvas uma vez que a atividade mercenária sofreu influência do mercado na privatização e terceirização da força e, desta forma, se tornou uma tendência e prática legal do setor privado. Como observa o documento:

Marketization, i.e. the growing role of the private sector in the outsourcing of security and military services, had become a new trend in mercenary activity, leading to a blurring of the distinction between mercenaries and those individuals working for legal PSCs (CHR, 2005: §12).

Se até o século XIX os exércitos privados eram uma realidade, ao fim do século XX começaram a recuperar proeminência. Após o fim da Guerra Fria a privatização da força armada foi alavancada devido, entre outros fatores, ao excesso de oferta de mão de obra qualificada militar deslocada em decorrência da redução dos estabelecimentos militares tanto no bloco comunista quanto no bloco Ocidental (Singer 2003, p. 53).

Nas guerras contemporâneas, também chamadas de Novas Guerras ${ }^{52}$, cada vez mais se exigia um novo tipo de militar com a "agilidade estratégica" para avaliar situações de modo rápido e implantar equipamentos e pessoal altamente treinado. Com a prevalência dos conflitos de baixa intensidade - onde não há uma linha de frente claramente delineada - os exércitos permanentes sofreram reduções aumentando-se a demanda por forças apropriadas para estes tipos de conflito. Assim, as tropas permanentes se tornaram suscetíveis de receber menos treinamento do que antes e, em consequência, muitos exércitos tornaram-se cada vez menos capazes de realizar tarefas profissionais ou ainda adquirir os recursos

52 Vide: Kaldor, Mary. New and Old Wars: organized violence in a global era. Palo Alto: Stanford University Press, 1999. 
adequados para realizá-las e, ao mesmo tempo, se preparar para o futuro (Dunning, 2010, p. 4).

A redução dos contingentes militares levou a uma enxurrada de pessoas com experiência no campo a se disponibilizarem para contratação no mercado militar privado. Segundo Avant (2007a), a demanda por habilidades militares se originava de vários lados: de países que buscavam atualizar suas forças armadas como uma forma de demonstrar credenciais para entrada em instituições ocidentais, de governantes de Estados fracos não mais apoiados pelas superpotências ao fim da Guerra Fria, bem como de atores não-estatais como empresas privadas e organizações não-governamentais (ONGs) que operavam nos territórios destes países.

Durante a Guerra Fria, o crescimento da terceirização no treinamento militar, consultoria, planejamento e inteligência foram feitos em graus inimagináveis (Leander, 2010). Após seu fim, ocorria uma reconfiguração das relações público-privadas que concebia um novo quadro no terreno político e econômico afetando as relações sociais como um todo. Uma destas reconfigurações é justamente a situação militar na década de 1990 que é associada ao que alguns autores se referem como "mercado da força global", "suporte militar externo" ou ainda como "indústria de segurança comercial ou global" (Abrahamsen \& Williams, 2006; Leander, 2010; Cockayne, 2009) ${ }^{53}$. E a indústria militar privada acabou por se estabelecer de vez após a invasão do Iraque em 2003 quando as forças da coalizão incluíam mais de 20 mil pessoas empregadas por empresas militares privadas (Cameron, 2006, p. 574; O'Reilly, 2008; Cockayne, 2006b) ${ }^{54}$.

Em termos mais amplos, a indústria de segurança comercial se refere a um mercado global onde as EMSPs oferecem, entre outras coisas, apoio militar em um trabalho com fins lucrativos. Este tipo de mercado é considerado como uma reconfiguração de formas mais antigas de mercenarismo e a terceirização contemporânea das EMSPs tem pavimentado o caminho para o surgimento de uma complexa rede de dependência dos serviços prestados, sejam eles

\footnotetext{
53 O termo "Indústria da Segurança Global" se remete ao mercado da força, mas não exclusivamente a esta, uma vez que na indústria cabem também as práticas multidisciplinares na reconstrução de Estados considerados falidos, por exemplo.

54 O'Reilly (2008), no entanto, considera a mercantilização dos serviços militares uma característica de longa data da ordem global sendo uma tendência estabelecida por governos ocidentais muito antes desenvolvimentos contemporâneos no Iraque (p. 01)
} 
relacionados diretamente à força, sejam trabalhos intitulados como em prol do desenvolvimento das comunidades atingidas por conflitos.

As EMSPs atualmente oferecem uma lista abrangente de serviços que envolvem a gestão de risco, defesa, guarda e até mesmo soluções de desenvolvimento. A partir deste cenário as discussões sobre a privatização da segurança e a mercantilização dos serviços militares são cada vez mais proeminentes como uma tendência estabelecida por governos ocidentais (O’Reilly, 2008). Como já mencionado, alguns supõem que essa tendência desafia as questões na esfera pública e em uma de suas mais fundamentais (como o liberalismo clássico uma vez alegou): o fornecimento de segurança como papel do Estado.

O Relatório do International Alert (Vaux et al, 2002) menciona o caso ressaltando que "a segurança não é mais um bem público prestado pelo Estado e, portanto, um direito de todos os cidadãos, mas um luxo para aqueles que podem pagar a expensas do pobre e vulnerável que não pode" (p. 30). Por outro lado, cabe interpretar a situação como a dificultosa divisão entre público e privado onde a ideia de segurança ou proteção pode ser gerenciada tanto como um bem público quanto uma mercadoria em uma dimensão mais ampla.

Neste sentido, observamos que a lógica que coloca os Estados e empresas privadas exclusivamente em dois pólos diferentes neste contexto se mostra de pouca ajuda. Alguns analistas veem a "mercantilização da força" como uma tendência por razões comerciais, outros consideram como meras extensões da política doméstica do Estado de origem (Leander, 2010). Shearer (1998 apud Leander, 2010) considera o fenômeno como "um instrumento nas mãos do Estado", ou seja, ao invés de enfraquecer o Estado, fortalece-o. Outros veem a privatização da indústria militar de um modo mais paradoxal, ou seja, em prol dos interesses do Estado e, ao mesmo tempo contra ele (Singer, 2001; O’Brien, 1998). Em outro lugar, sugere-se que "os mercados privados abrem o caminho para novas formas de imperialismo descentralizado enfraquecendo os Estados mais fracos” (Francis, 1999; Musah, 2002 apud Leander, 2010).

A proeminência das EMSPs na história do pós Guerra Fria torna-se ainda mais notável para os nossos propósitos por ser um período de tempo em que a prestação de assistência humanitária por algumas dessas empresas se verifica como um fenômeno antes não encontrado. Independentemente de a agenda das 
EMSPs serem próprias ou sempre vinculadas a um governo de um país, encontramos nas práticas humanitárias oferecidas por estas empresas um universo de questões sobre a direção que a política no campo se encaminha. A atenção que se quer priorizar, no entanto, é sobre como se tem configurado a política desse novo agenciamento que se conforma no campo humanitário. Como observado no capítulo anterior, os discursos advindos desse quadro vão contribuir para novas visões a respeito do significado, inclusive, da humanidade. Neste caso, ao invés de um simples hibridismo na natureza organizacional das EMSPs contemporâneas, a imiscuição no campo da discursividade humanitária permite que as EMSPs e as agências humanitárias se vejam como produtoras de práticas muitas vezes indistintas em seus efeitos. O progressivo movimento de indiferença institucional entre contratação e associação, faz da prática humanitária um fenômeno altamente contestável para os mais tradicionalistas e, consequentemente, coloca o humanitarismo num campo de disputa no processo de significação.

Pode-se questionar, no entanto, qual a relação das EMSPs que estão envolvidas com ação humanitária e as práticas multidimensionais de desenvolvimento e segurança. A relação se dá pela capacidade progressiva das EMSPs de atualmente manejarem os discursos e sua mercadoria atravessando estes três universos. Alguns autores que chamam atenção para o vocabulário em emergência desde os anos 1990, afirmam que associações institucionais de diferentes naturezas são cada vez mais prováveis na governamentalidade liberal (Esteves, 2010a; Duffield, 2001; Neumann, 2010); essas associações chegam a ser mencionadas como parte de um conjunto de discursos e práticas ligados ao que se tem chamado de nexo entre segurança, desenvolvimento e humanitarismo (Esteves, 2010a; Souza, 2010), algo que a indústria comercial de segurança também faria parte.

Se o processo ao qual as EMSPs se inserem está mais para uma inovação institucional necessária nos novos tempos do que para uma apropriação indevida de tarefas humanitárias é precipitado e talvez ingênuo de se afirmar, mas não se pode refutar a abertura para a possibilidade de transformação do sentido moral da atividade humanitária neste contexto. As práticas que se enquadram na tríade da "segurança-desenvolvimento-humanitarismo" são outras formas de discursos com o objetivo de buscar legitimação ou hegemonia. 
Seja por meio de autorizações normativas, internalizações e fusões de vocabulários, em poucas décadas a possibilidade de normalização da prática humanitária de origem militar e privada é tão possível quanto a realidade das práticas de construção do Estado contemporâneas. Estas narrativas são condições de possibilidade para a realização de um projeto cuja política se assemelha ao movimento de disputa hegemônica. Essa disputa é pela legitimidade e pelo poder de definir nomes. E os novos atores humanitários se encaixam adequadamente na circunscrição das fronteiras liberais que lhes permitem associar a conveniência de uma ideia poderosa de humanidade e a finalidade de atingir as projeções de mercado necessárias para a manutenção de sua instituição no tempo ${ }^{55}$.

\subsection{As EMSPs modernas e suas condições de existência}

As práticas das empresas de segurança privada nos dias atuais não são resultados de meros contratos formulados por governos e organizações incapazes de processar as demandas do campo humanitário. A expansão titânica da indústria das EMSPs é fruto de processos com oportunidades discursivas imprescindíveis surgidas após o fim da Guerra Fria. Este seria um momento histórico que coincidiria as exigências estruturais para força de trabalho mais qualificada com o aumento da percepção dos riscos relacionados aos trabalhadores humanitários, o que abria oportunidades para o engajamento de mais atores na assistência humanitária. O contexto de surgimento e estabelecimento de "operações multidimensionais" foi e continua a ser significativo para agentes de segurança privada gerenciarem narrativas distintas de proteção, defesa e segurança.

\footnotetext{
${ }^{55} \mathrm{O}$ vocabulário da paz liberal abriu caminho para ações multidimensionais que, por sua vez, sustentam até hoje as operações de construção do Estado como parte de um quadro muito mais amplo de governança (Duffield, 2001; Esteves, 2010a; Chandler, 2002). A complacência entre militarismo privado e humanitarismo, segundo este trabalho, advém da mesma lógica. Os autores que lidam com tema da governança global geralmente interpretam-na como forças que são "fluidas, mutáveis, [territoriais] e não territoriais" e como processos de "crescente ênfase em acordos regionais de segurança, mandatos por meio de subcontratação e outras formas de delegação autoridade". Isso configura uma rede de "diferentes organizações, grupos de interesse e formas de autoridade em relação às funções de regulação específicas" em que o paradigma dominante é liberal (Duffield, 2001, p. 44). As EMSPs são aqui consideradas, portanto, como parte dessa rede e se ajustam progressivamente às tarefas requeridas para gestão global da segurança, e das formas mais plurais.
} 
Alguns autores consideram que este acoplamento tenha se iniciado em situações de emergência e, em seguida, em operações em que predomina a ligação entre a segurança, humanitarismo com características desenvolvimentistas. De modo notável, as narrativas de proteção apresentadas pelas EMSPs são geralmente mobilizadas segundo uma lógica que reitera o discurso dos Estados frágeis ou falidos cuja sobrevivência por suas próprias forças necessitaria de um apoio prévio de agências de segurança e desenvolvimento competentes, um compromisso que as EMSPs se prontificariam a cumprir. Os discursos humanitários dos provedores de segurança privada passaram a manejar uma política de proteção que produz sua própria demanda e também os ajuda a estruturar e pressionar por interpretações específicas a sua agenda política e econômica. Ao educar outros atores em sua moldura interpretativa a respeito da segurança no campo de trabalho das agências humanitárias, as EMSPs acabam por vincular a necessidade de sua presença nos espaços chamados "subgovernados".

Neste fim, o aumento no número de contratos de EMSPs após o fim da Guerra Fria não pode ser visto simplesmente como uma consequência das oportunidades de mercado na indústria de guerra. Está relacionada com uma pluralidade de discursos que emergem de debates, principalmente na década de 1990. As dimensões em que termos como "humanitário" e "ajuda" são usados trazem questões importantes para compreender as práticas e justificativas das EMSPs em operações distintas.

Um tipo mais específico de contratação de EMSPs no mundo contemporâneo está relacionado direta ou indiretamente aos contratos no domínio das agências humanitárias. O quebra-cabeça está no fato de alguns contratos estipularem deveres que são multidimensionais por natureza e com papéis estabelecidos de maneiras antes incomuns à história das agências humanitárias mais tradicionais como o CICV e o grupo dos MSF.

Pela dificuldade de enumerar o tamanho dos contratos e a quantidade de EMSPs envolvidas com práticas humanitárias multidimensionais, perguntei diretamente a Doug Brooks, presidente do ISOA, o que ele tinha a dizer a respeito do engajamento das EMSPs com a ação humanitária e da relação moral da indústria militar com tais atividades. Também lhe perguntei o que o ISOA entendia como ação humanitária, uma vez que muitas empresas são contratadas 
igualmente para operações de contrainsurgência e Peacekeeping. Em resposta, Brooks (2014) demonstrou não apenas a multidimensionalidade das operações, mas também o caráter naturalizador que a lógica de mercado propõe para a prática humanitária no pós-Guerra Fria. Abaixo encontra-se a resposta de Brooks:

Companies can work for any legal client, and many are hired to support humanitarian operations or NGOs that are doing humanitarian operations.

The Stability Operations Industry encompasses any company that provides services in conflict, post-conflict or disaster relief environments. So you are correct, logistics, construction, infrastructure reconstruction, medical services, aviation services, landmine removal - and many other services could be considered humanitarian services. For employees of the companies, they love doing that sort of work, but ultimately the companies are contracted normally, although the clients may be different.

Beyond the logistics and construction already mentioned, about $10 \%$ of the industry does security and risk management, and much of that can be related to humanitarian operations. Advising NGOs on how to stay safe in places like Haiti or Somalia has some value and might be considered 'humanitarian'. (...) Many companies offer Kidnapping and Ransom services/insurance (K\&R) which most of the big humanitarian organizations have for their employees. Essentially, if an employee is abducted the company will send a specialist to advise the NGO and the friends and relatives of the victim, and to negotiate for the safe release of the hostage.

So yah (sic), the industry has a pretty big role in humanitarian operations, but I don't think there is any clear definition of whether they are officially 'humanitarian' or not when they do these forprofit operations. Ultimately, they are not making the decision when and where to do an operation, they are simply hired to make the project happen or to support the Project (Brooks, 2014, entrevista).

A razão pelas quais algumas práticas foram incorporadas não é o foco da pesquisa, mas sim o modo como se desenvolveram. No cerne das transformações que ocorreram após o fim da Guerra Fria, está a ampliação das interpretações sobre a segurança e, consequentemente, sobre a "proteção" como um ponto interessante não apenas para as EMSPs, mas também para uma variedade de atores que visam dar sentido a sua presença em operações de manutenção e construção de paz, de estabilização, de contrainsurgência, e assim por diante.

$\mathrm{Na}$ pluralidade de funções desempenhadas por EMSPs no domínio do humanitarismo, há uma conexão artificial entre a justificativa relatada por alguns 
humanitários e as funções exigidas pelo EMSPs em locus. Os contratos são muitas vezes justificados pelo aumento da violência contra os funcionários no campo $^{56}$ e por algum tempo as equipes enviadas por EMSPs eram em sua maioria contratadas por organizações de ajuda humanitária para servir como agentes de segurança (Van Brabant, 2002). Antes da diversificação das EMSPs, ocasionalmente se viam guardas armados fazendo a escolta de funcionários de alto escalão, como oficiais do governo ou da $\mathrm{ONU}$, mas isso passou a não ser mais a realidade predominante nas operações mais recentes uma vez que vários militares privados também eram contratados por agentes humanitários locais para cuidar de sua segurança (Cockayne, 2006b). A razão para o aumento dos contratos se daria pelo crescimento da violência, tais como intimidações, sequestros, lesões e mortes durante operações de ajuda humanitária que em alguns casos tiveram que ser suspensas ou canceladas completamente (Spearin, 2008). No entanto, as funções que estão sendo executadas por EMSPs vão muito mais além da guarda de indivíduos que carecem de trabalhar em segurança. As atividades se expandiram ${ }^{57}$.

Alguns autores costumavam mencionar que a "privatização da força militar na ordem internacional atual não é exclusiva dos últimos tempos” (Kinsey, 2006), mas se não são um fenômeno novo, o que pode ser então questionado é se o diferencial no processo de privatização da força armada nos dias atuais seria justamente o engajamento das EMSPs como provedores de assistência humanitária. A contratação de provedores de segurança em todo o mundo abrange, por exemplo, vigilância por satélite, inteligência terrestre, avaliação de riscos, manutenção de equipamentos, operação de linha de frente da tecnologia e equipamentos, supervisão de forças, programas abrangentes de reforma do setor

\footnotetext{
${ }^{56}$ Sobre este tema ver Vaux et al (2002), Smith (2002), Baker and Pattisonm (2009), HPG (2008), Spearin (2008), Currier (2003), etc.

${ }^{57}$ Cabe constatar, no entanto, que muitos autores preferem considerar esta justificativa como um elemento mais subjetivo, i.e., da percepção de perigo; não havendo comprovação suficiente se haveria mais violência atualmente no campo do que em períodos anteriores. Segundo o relatório do HPG (2006), há uma percepção generalizada dentro da comunidade de ajuda internacional de que os atos graves de violência contra trabalhadores humanitários teriam aumentado nos últimos anos. Essa percepção teria feito com que os atores humanitários mudassem sua abordagem sobre as equipes que trabalham com segurança pessoal e suas operações de ajuda. O relatório menciona, no entanto, que "não existe nenhuma análise empírica detalhada para apoiar ou refutar as alegações sobre o aumento da violência contra os trabalhadores humanitários em uma escala relativa, isto é, medindo-se em relação ao número de trabalhadores humanitários que atuam no campo. Esta lacuna no conhecimento fez com que a política e as respostas operacionais às condições de segurança fossem em grande parte impulsionadas por impressões e evidências anedóticas e tendências importantes não foram identificadas" (HPG, 2006, p. 01).
} 
de segurança durante conflitos, etc., (Rosén, 2008). Eles diferem em tamanho, poder relativo, localização no sistema internacional, nível de riqueza, número e tipo de adversários bem como em termos de imagem organizacional, ideologia, legitimidade, objetivos, e assim por diante (Singer, 2001).

$\mathrm{O}$ crescimento do número de empresas militares e de segurança privada como parte do mercado da força é geralmente entendido como resultado de demandas estruturais nos assuntos de segurança e de interesses estratégicos dos seus usuários (Estados e atores não estatais) que preferem a terceirização da força de trabalho mais qualificada e também se desoneram de uma grande quantidade de problemas jurídicos, burocráticos e logísticos.

No caso do campo humanitário, as reivindicações por segurança que fundamentam a necessidade das EMSPs são colocadas por Cockayne (2006a) em três tipos diferentes, embora inter-relacionados, de demanda: (1) uma que resulta de um aumento real dos ataques a trabalhadores humanitários, (2) uma que está relacionada ao aumento da percepção subjetiva do risco entre o pessoal humanitário e (3) uma demanda que resulta da vontade própria das agências em manter a presença dos militares privados em situações de conflito crônico ou em curso, a fim de conseguir maiores financiamentos dos doadores.

Estes pontos resumem a maneira em que a proliferação dos provedores de segurança é estabelecida em termos da lógica de "oferta-demanda" e mostra como o pensamento pragmático pode reforçar as soluções comerciais na medida em que o trabalho das EMSPs é considerado responsável, profissional, preciso e uma opção potencialmente mais barata na competição do mercado da proteção.

Antes de 1990, as EMSPs não estavam engajadas em apresentar a proteção ou prevenção como questões centrais em seus portfólios. Nem a "ajuda humanitária", nem "entrega de alívio" eram atividades citadas em sua lista de serviços de excelência. O tempo de início deste tipo de papel específico no setor militar privado é muitas vezes referido à década de 1990, quando governos e agências da ONU cada vez mais se voltaram a essas empresas para suporte de segurança em operações de emergência (Vaux et al, 2002) e também se menciona o ano de 2003 quando o uso de EMSPs no campo do humanitarismo e do desenvolvimento foi observado pelo aumento das parcerias entre estas empresas e os militares dos EUA e entre o Departamento de Estado. Por vezes também podem-se notar considerações sobre o setor militar privado nos EUA ter surgido 
durante as operações humanitárias de 2005, após o desastre do furacão Katrina em Nova Orleans, algo que se remete aos incidentes passados em Serra Leoa quando o Executive Outcomes ${ }^{58}$ trabalharam com grupos humanitários para proteger os civis nas áreas em que controlavam (Cockayne, 2006a, p. 36).

A pesquisa do Overseas Development Institute indica que os serviços humanitários das EMSPs cobrem uma grande variedade de atividades, mas, inicialmente, os contratos eram simples no escopo. Como se vê neste relatório:

[S]ervices humanitarians used most were security training for staff, security management consulting and risk assessment/threat analysis. The most popular services from local private security providers were unarmed guards (for facilities, residences and project sites) and physical security for premises" (HPG, 2008).

Considerando este cenário, o contínuo que vai desde a logística até a guarda de pessoas não é mais, contudo, uma imagem que retrata precisamente as EMSPs. Eles agora mobilizam discursos de proteção para trabalhar em uma área de segurança mais ampla. Como já foi sugerido, os eventos de transformação e os discursos decorridos após o fím da Guerra Fria preparam um terreno para atividades das EMSPs expandirem para novos domínios. Como exemplo, o International Code of Conduct for Private Security Service Providers Signatory Companies (2013) é um documento de 252 páginas em que o substantivo "proteção" aparece 511 vezes, uma quantidade significativa para as 659 empresas signatárias e listadas até junho 2013. Cada empresa fornece sua própria descrição sobre quem são, onde estão e o que fazem. A palavra "proteção", em seus vocabulários próprios, é subsequentemente seguida ou antecedida por palavras de diferentes áreas de conhecimento, como pode ser visto em alguns exemplos na figura 04.

\footnotetext{
${ }^{58}$ Executive Outcomes, geralmente referidos como um exército mercenário, é uma empresa militar privada com sede em Pretória, África do Sul, e composta em sua maioria por ex-membros da Força de Defesa Sul Africana. Para sua história ver "Khareen Pech and David Beresford. Africa's new-look dogs of war, Weekly Mail \& Guardian, Jan 1997".
} 


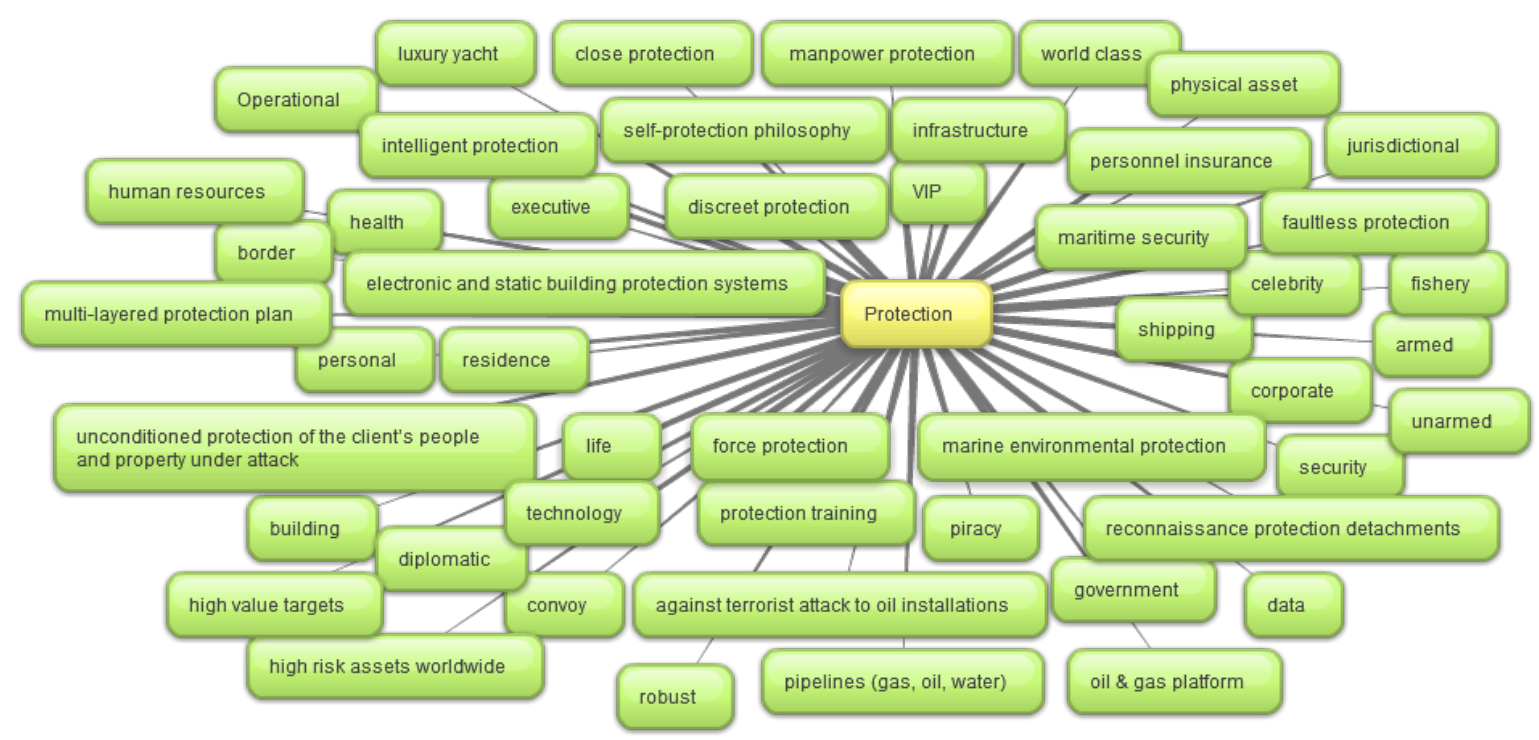

Figura 04: Vocabulário da proteção

As rotinas de segurança que utilizam o vocabulário da proteção também incluem a coordenação das ações preventivas muito amplas que mostram que as EMSPs são entidades que visam estabelecer-se com alto nível de experiência no mercado da segurança. Como o chefe de segurança no Secretariado do Ministério da Suécia explicou em uma entrevista,

[They] help organize security and make sure that it works... this means keeping an eye on the security guards... organize convoys... work with contingency planning and safety and security instructions. And then a very important issue when it comes to security, which is preventive security... having an information advantage is extremely important (Berndtsson, 2012, p. 314).

As práticas de proteção e prevenção na indústria da segurança privada não podem ser analisadas apenas pelo prisma do mercado ou das circunstâncias políticas. Eles são parte de um conjunto muito mais amplo de narrativas compartilhadas para além do setor de segurança. A expansão da indústria da ajuda também é significativa para a construção do contexto normativo enredado nas 
complexidades estruturais impulsionadas por mudanças no sistema internacional na década de 1990 e as oportunidades dadas ao setor privado. As crises humanitárias ganham relevância aqui no que tange ao crescente movimento de adequação das EMSPs a tais crises e o aperfeiçoamento no fornecimento de serviços relacionados à proteção e prevenção no campo de ação das agências humanitárias. Entretanto, curiosamente, no código de conduta internacional dos provedores de segurança privada, anteriormente citado, as empresas signatárias não mencionaram nenhuma conexão imediata para com a indústria de ajuda humanitária.

Algumas das mais conhecidas EMSPs que prestam serviços humanitários optaram por não mencionar esta informação neste documento; no entanto, elas fazem o oposto em outros canais de mídia como sites e relatórios de congressos ${ }^{59}$. Das 659 empresas signatárias do documento apenas onze empresas ${ }^{60}$ mencionaram algum tipo de envolvimento em serviços humanitários, mas nenhuma destas faz parte do ciclo de grandes contratos de entrega de ajuda humanitária. As onze empresas são majoritariamente de fornecimento logístico. Para mencionar algumas, três das empresas signatárias do Código de Conduta Internacional que são muito conhecidas por trabalharem com a assistência humanitária são DynCorp, Aegis e EODT (agora chamada de Sterling Global Operations). Contudo, nenhuma delas mencionou algum tipo de serviço "humanitário" no documento e o tamanho do escopo de ação em que se inserem torna nebulosa a razão da supressão da informação no documento. Algumas das atividades denominadas humanitárias por estas empresas estão representadas na Tabela 01 .

Seria precipitado julgar o significado deste silêncio devido à natureza do documento, mas para o momento é importante indicar algumas questões sobre o caso. Por um lado, se compararmos tal ocultação com os sites das empresas é provável que o uso da narrativa da assistência humanitária seja mais revelador para fins de propaganda e reputação direcionados a um público maior do que poderia ser publicado em um documento burocrático. Por outro lado, o

\footnotetext{
${ }^{59}$ Vide Tabela 01.

${ }^{60}$ Indefatigable Protective Services International Inc., International Ocean Logistics, Kanchanjangha Security Services, RedLine Security S.A., RSB GROUP, Sentinel International, Spitfire Global, Tactical Solutions International, Gabriel Security Services, Triskelion Alliance, S.A, Universal Eagles for Security Services Ltd.
} 
documento com o qual estariam mais preocupadas em se identificar seria o International Code of Conduct for Private Military Service Providers (ICoC) de 2012, que se diferencia do documento de 2013 mencionado anteriormente pelo fato de não se limitar à provisão apenas de serviços de segurança, mas também serviços militares. O ICoC se trata de uma iniciativa promovida pelo governo da Suíça e um meio encontrado pela indústria das EMSPs para autorregulação de acordo com o DIH e com os Direitos Humanos. Como pode ser visto no preâmbulo, o Código foi construído para que as empresas de segurança privada “desempenhem um papel importante na proteção de clientes estatais e não estatais envolvidos na assistência, recuperação e reconstrução, nas operações de negócios comerciais, diplomacia e atividade militar" (ICoC, 2012, parag. 1). Os objetivos políticos mais elementares de governança aparecem mais claramente no parágrafo 3 , da versão do esboço de $2012^{61}$ :

Building on the foundations of the Montreux Document (2008), which articulated pertinent state obligations under international humanitarian law and good practices for the use of Private Military and Security Companies in situations of armed conflict, the ICoC launched a broader initiative to promote better governance, compliance and accountability for Private Security Companies and other Private Security Service Providers (collectively "PSCs") operating in complex environments (ICoC, 2012, preâmbulo) ${ }^{62}$.

E a versão final já exprime mais claramente as responsabilidades humanitárias e de Direitos Humanos:

The Signatory Companies affirm that they have a responsibility to respect the human rights of, and fulfil humanitarian responsibilities towards, all those affected by their business activities, including personnel, clients, suppliers, shareholders, and the population of the area in which services are provided. The Signatory Companies also recognize the importance of respecting the various cultures encountered in their work, as well as the individuals they come into contact with as a result of those activities (ICoC, 2012, Parag. 3).

\footnotetext{
${ }^{61}$ De modo interessante, a versão final do ICoC retirou esta versão do preâmbulo, substituindo por: "Building on these foundations, the Signatory Companies to this International Code of Conduct for Private Security Service Providers (the "Code") endorse the principles of the Montreux Document and the aforementioned "Respect, Protect, Remedy" framework as they apply to PSCs. In so doing, the Signatory Companies commit to the responsible provision of Security Services so as to support the rule of law, respect the human rights of all persons, and protect the interests of their clients" (Parag 3).

62 Vide: http://www.icoc-psp.org/uploads/Draft_Charter.pdf
} 
Aparentemente, é do interesse da indústria de segurança privada ser parte de um quadro legal quando se envolve nas tarefas de segurança, entrega de ajuda ou similares, no entanto, o imperativo moral e as narrativas de progresso sobre os quais as empresas se deitam para justificar a expansão da gama de serviços em diversas operações não são sempre coincidentes entre si. A preocupação central quando as EMSPs sumarizam suas atividades, portanto, jamais poderia se desvincular da função para o qual foram criadas: gerar lucros exponenciais por meio aperfeiçoamento de seus serviços. Esse é um dos maiores desafios para o humanitarismo tradicional na modernidade. 


\section{A expansão das ONGs humanitárias}

\subsection{O encontro de discursos expansivos}

As Organizações Não Governamentais desde o início de 1990 se deparavam com grandes oportunidades de expandirem seu engajamento em áreas onde o poder do Estado fosse considerado fraco ou enfrentasse significativa instabilidade doméstica ou em seus entornos fronteiriços. Sejam em territórios antes pertencentes à União Soviética ou em países africanos após o fim da Guerra Fria as instituições privadas começaram a considerar a necessidade de dedicar atenção às questões de segurança nestes ambientes e se viram obrigados a desenvolver os seus próprios planos de segurança a fim de atingir seus objetivos. Segundo Avant (2007b, p. 146), “embora o processo tenha sido diferente para cada uma, tanto as ONGs quanto as empresas procuravam opções de segurança que considerassem 'apolíticas' e, ao fazê-lo, desenvolveram uma concepção de segurança que é distinta da concepção tradicional”.

A concepção tradicional discute questões de "ameaça, inimigo e uso da violência" e ONGs humanitárias ou de desenvolvimento costumavam lidar com esse modelo de modo passivamente estratégico para dar seguimento aos trabalhos de ajuda em campo. No caso do CICV esse posicionamento diz respeito ao compromisso com a independência e imparcialidade por parte da organização. Outras organizações que se viam incapazes de lidar com as consequências desafiadoras de optar por um posicionamento "apolítico" muitas vezes escolheram se retirar do espaço de provisão de ajuda e alívio. No entanto, na década de 1990 emergiam narrativas - não apenas do campo prático, mas também do espaço acadêmico - que visavam recriar o modo como as instituições deveriam lidar com o tema da segurança. 
O discurso da necessidade de expansão do conceito de segurançca ${ }^{63}$ foi, sem dúvida, um dos mais relevantes para a transformação dos moldes com que as políticas de âmbito internacional seriam implantadas a partir da década de 1990. Alguns eventos, contudo, foram estopins para a necessidade de reformulação das ideias tradicionais de segurança. A missão da ONU na Somália, em 1992, por exemplo, colocou as ONGs humanitárias em posições de destaque na resposta inicial para a seca e a fome no país, mas igualmente desafiou como estas agências enxergariam certos princípios então caros para a concepção tradicional de ajuda humanitária uma vez que se viram cercadas por banditismo e extorsão de senhores da guerra rivais (Avant, 2007b). Ademais, após a intervenção das tropas da Força Tarefa Unificada ${ }^{64}$ a relação entre as agências e os militares desafiava o propósito o qual as ONGs se atribuíam.

Segundo Avant (2007b), a abordagem de segurança dos militares interromperam as práticas de aceitação das ONGs e foi um exemplo do que se tornaria um confronto entre as culturas das agências humanitárias e os militares. Isso se deu, porque os militares dos EUA desejavam implantar uma força esmagadora para garantir a segurança, mas as agências viam a "Operação Restore Hope" como uma tarefa desproporcional e separada do que consideravam como esforço de ajuda humanitária. Segundo Avant (2007b), a missão na Somália também foi o início do que viria a ser considerado como uma mudança radical no interesse dos doadores que antes estavam mais focados na "ajuda ao desenvolvimento" e que se direcionariam às ONGs de ajuda humanitária. Contudo, isso não significa uma transposição do financiamento para as agências humanitárias em detrimento das ONGs voltadas para planos de desenvolvimento; o que ocorre é um amalgamento de agendas advindo não apenas da pressão dos doadores sobre as já estabelecidas organizações, mas também via proliferação de novos atores na indústria da ajuda humanitária. Em entrevista à Avant (2007b), o então diretor de segurança do Save the Children, Michael O'Neill menciona que:

\footnotetext{
${ }^{63} \mathrm{~A}$ transformação normativa provocada pela expansão do conceito de segurança e, mais precisamente, sua relação com o conceito de Segurança Humana estão desenvolvidas na próxima seção.

${ }^{64}$ Do Inglês Unified Task Force (apelidada de Operation Restore Hope), foi uma iniciativa liderada pelos EUA que intervieram na Somália em 1992 com uma força multinacional sancionada pela ONU.
} 
With donor interest - and money - came many new 'humanitarian' actors, some moving from other areas (like development) and others entirely new. Many of these had little familiarity with humanitarian principles and standards and launched projects in the field that threatened the security associated with the traditional acceptance strategy (Avant, 2007b, p. 147).

A abertura institucional das agências humanitárias também chamou a atenção dos analistas para a reconfiguração da política identitária onde a militarização e o mercado encontrariam a assistência humanitária. Como no caso das EMSPs, tem-se uma adequação entre elementos humanitários e interesses de caráter comercial. A oferta de ajuda humanitária ou de serviços assim chamados, a despeito de nem mesmo as agências humanitárias oferecerem os mesmos (e.g., desminagem, construção urbana, etc.) coloca os atores humanitários em posição de rivalidade com uma série destas empresas pelo desafio que levantam à identidade das organizações que basearam sua legitimidade em sua condição desmilitarizada. No entanto, quando na situação de não ser possível impedir atos violentos direcionados a atores humanitários, e na iminência de terem que se retirar do espaço humanitário, algumas agências começaram a considerar a possibilidade de fazer uso das opções de segurança disponíveis no setor privado.

No contexto dos desastres de Ruanda, a CARE Canadá, por exemplo, publicou um relatório sob o título Mean Times aconselhando que as ONGs internacionais que oferecem ajuda humanitária considerassem a contratação direta de EMSPs a fim de se manterem no campo. Como observa o relatório:

The report notes that humanitarian organizations in general, and the non-governmental sector in particular, are locked into a set of intractable dilemmas in situations where poverty, violence and famine come together. NGOs work under conditions where the increased unwillingness of national and international government to engage in political-military action often results in perverse and unintended consequences for the intended beneficiaries. The report identifies steps humanitarians should begin to take to measure these negative consequences and consider appropriate strategic and political responses. Among these steps are that in the absence of publicly funded security, serious consideration be given to engaging private military forces. And further, that humanitarian NGOs be willing and able to withdraw their services when it is clear beyond doubt that disengagement is the option that would cause the least harm to victimized populations (CARE, 1999). 
Nesta mesma linha, uma grande quantidade de atores resolveram vocalizar sua insatisfação com a condição "apolítica" no campo em casos de graves crises de violação dos direitos humanos e argumentaram seu apoio às ONGs e à comunidade internacional para defenderem um papel mais ativo na "responsabilidade de proteger" os indivíduos em países que não podem ou não têm condições de protegê-los (Avant, 2007b). Estes argumentos foram feitos inicialmente dentro de ONGs com foco nos direitos humanos até as organizações de ajuda humanitária começarem também a refletir essa lógica posteriormente.

O discurso da "responsabilidade de proteger" bem conhecido pelo paradoxo do salvamento pelo sacrifício com uso impositivo da força tem sido um grande tema de discussão e atualmente se localiza numa linha tênue entre ação e intervenção humanitária. Diz-se tênue, porque a permissividade do que se designa como ação humanitária era uma narrativa mais própria das práticas caritativas tradicionais. Ação era um nome necessariamente manejado como contraponto das práticas intervencionistas dos Estados, e portanto, opunha-se à intervenção. No entanto, a despeito dos esforços de alguns, a imiscuição entre ambas as palavras é paralela ao fenômeno da relativização da soberania em nome da causa chamada humanitária. Não se trata apenas de um processo em que a ideia da suspensão do direito de soberania reflete a política de poder dos Estados, mas se trata igualmente do caso onde interesses estratégicos coincidem com o discurso de uma moral de uma humanidade expansiva, como visto no capítulo 1. A moral humanitária, semelhantemente à política de guerra contra o terror, mistura justiça, dever e sensibilidade de modo a estabelecer normas que de outro modo seriam extremamente difíceis.

A indiferença interpretativa entre ação e intervenção humanitária é, portanto, parte de um quadro de discursos que abre possibilidade para um outro regime de tratamento para temas que envolvem a humanidade, algo que muitas vezes se assemelha ao que se poderia designar como um regime de exceção humanitária.

Didier Fassin \& Mariella Pandolfi (2010) preocupando-se com os regimes de exceção contemporâneos fazem um mapeamento entre as singularidades no intervencionismo de agora em relação ao passado. Segundo os autores, o intervencionismo contemporâneo se destaca pela primazia da razão moral em 
relação aos princípios políticos. Ainda que a moralidade sempre tenha tido seu lugar, por exemplo, na justificação da guerra, no caso da política das intervenções humanitárias tem-se a moralidade humanitária como elemento central no discurso dos Estados. O intervencionismo antigo, enquanto que usava argumentos morais para determinar se havia base para intervir em defesa de um Estado fraco, não o fazia, contudo, em ordem de proteger uma população e salvar vidas como na atualidade (Fassin \& Pandolfi, 2010, p. 12). O relato é de que existe um estado de exceção que progressivamente se estabelece no nível global principalmente a partir das duas últimas décadas onde haveria um tipo de "terra de ninguém" entre o direito público e a política e entre a ordem jurídica e a própria vida dos indivíduos, uma biopolítica global (p.15).

A moral intervencionista além de carregar uma capacidade de acomodação de discursos que em princípio seriam diversos, também acomoda uma habilidade para superação de antagonismos entre atores de setores diferentes da sociedade. Como mencionado, a preocupação com segurança dos indivíduos une a figura do protetor e do protegido sob a égide da preservação do corpo, seja este físico ou institucional. O corpo militar, o corpo das agências de alívio, o corpo do civil e as 'corporações' privadas, sejam estas petrolíferas, mineradoras, empresas logísticas, e assim por diante; todos os corpos precisam de alívio agora. E quando necessário, a intervenção militar seja pública ou privada vai ao encontro de reinvindicações por mais justiça e responsabilidade para proteger os indivíduos em situação de emergência e também não emergenciais.

O dever muitas vezes é inversamente proporcional ao direito. Quando Tony Blair conclamou uma intervenção humanitária no Kosovo em 1999, ou quando George Bush o fez repintando como assistência humanitária em 2003 no Iraque, ficava claro que o argumento humanitário era a possível chave para potencialmente transpassar os limites do direito internacional. Como mencionam Fassin \& Pandolfi (2010), houve uma transição da legalidade em direção à legitimidade segundo a qual a proteção das pessoas tomaria precedência sobre a soberania dos Estados e a validação das Nações Unidas seria um formalismo não mais tomado como impreterível.

Contudo, o discurso da moral humanitária não se difere de outros discursos em termos de sua capacidade de ser interpelado. O conhecimento por parte dos grandes ciclos de poder é forte o bastante para se fazer crer que o estado de 
(in)segurança das populações vulneráveis torna necessária a tomada de certas decisões em relação aos direitos civis. Os direitos coletivos e individuais podem ser considerados obstáculos para prevenção de possíveis incidentes ou catástrofes de magnitudes maiores. Seja na distribuição de ajuda no espaço humanitário ou na permissão do direito à privacidade do cidadão de países mais abastados, espalham-se discursos de que o rebelde é beneficiado pelo direitos gerais e para o bem de todos faz-se necessário suspendê-los em nome da ordem e da segurança ${ }^{65}$.

O regime de exceção, portanto, pode ser tão parte da assistência humanitária quanto dos contextos de guerra que possivelmente venham torná-lo necessário. Quando atores humanitários justificam a ação militar em nome de uma razão humanitária, tanto humanitários quanto militares compartilham a "temporalidade da emergência" (Fassin \& Pandolfi, 2010, p. 15), precisamente por rejeitarem a soberania dos Estados e similarmente engajarem-se na extralegalidade e extraterritorialidade justificada por uma moral de ordem superior e pela legitimidade com que suas decisões foram aplicadas. Essa temporalidade pode se tornar perene por meio de contínuas tentativas de persuasão de que, por razões de segurança, não é possível restabelecer a normalidade da ordem em um determinado território. Estes espaços de exclusão vão de corredores a enclaves, de bairros a toda uma região. Assim, essa espacialidade da exclusão que também é denominada de proteção não mais se encontra necessariamente sob o monopólio legítimo da violência do Estado e todas as decisões políticas que lhes concerniriam em outro tempo passam a ser normalizadas pelos então interventores como meras medidas operacionais (p. 16).

Fassin \& Pandolfi (2010) descrevem o estado contemporâneo de exceção como "desejo de intervir", algo que se revela na compaixão pelo sofrimento alheio e distante e que se traduz numa obrigação moral de agir como "uma das emoções políticas mais fortes da vida contemporânea" ou como as "fundações afetivas" que não são nacionalistas como nas situações tradicionais de guerra, mas universalistas em escopo ou simplesmente "humanistas" (p.16).

\footnotetext{
${ }^{65}$ Compreende-se aqui que o regime de exceção se expande para a realidade não apenas dos Estados com altos índices de violação de direitos humanos localizados no Sul Global, mas também do Norte, onde o espelho reflete sobre a suspensão dos direitos civis e na intervenção do militarismo na vida pública e privada.
} 
O problema político que emerge do papel militar sob a roupagem privada e humanitária num regime como este é de que a sua função fundamental seria de vigilância e prevenção. A adequação entre fazer o bem e a coleta de informações de inteligência passam a ser recursos sem discussão ética. A medicalização do que é ameaçador e a imobilidade do que é vulnerável se tornam, pois, sinônimos de segurança.

\subsection{A segurança humana como ponto nodal}

Com o fim da Guerra Fria e a consequente dissipação do discurso da bipolaridade, as questões de segurança deixavam de ser associadas predominantemente ao escopo da segurança militar para dar lugar a outros elementos antes adormecidos ou pouco discutidos no âmbito internacional. Com a mudança da estrutura discursiva do cenário internacional, discutia-se a necessidade de reformulação de políticas de segurança e de manutenção da paz perante o aumento dos conflitos civis e de seus efeitos nefastos sobre a população local dos países afetados e potencialmente para os países vizinhos em termos de escalonamento de crises humanitárias.

A discussão sobre o desenvolvimento como medida condicional para a paz ganhava força e passaria à categoria de proposta dentro do Programa das Nações Unidas para o Desenvolvimento (PNUD) ainda nos anos 1990. No Relatório de Desenvolvimento Humano do PNUD de 1994, considerado o documento que mais recentemente levou o conceito de segurança humana aos estudos tradicionais, o conceito é conhecido como "a prerrogativa do indivíduo, [que] liga o conceito de segurança inseparavelmente à ideia dos direitos humanos e da dignidade para o alívio do sofrimento humano" (CHS, 2003, p. 01 apud NdlovuGatsheni \& Dzinesa, 2008, p. 87). Em 2003, a Comissão Internacional sobre a Segurança Humana apresentou o seu relatório à ONU propondo que a segurança humana fosse o novo paradigma para lidar com as ameaças enfrentadas no século XXI e em 2005, os chefes de Estado reunidos no World Summit Outcome adotaram finalmente o conceito de segurança humana para que as pessoas tivessem "o direito de viver em liberdade e dignidade, livre da pobreza e do desespero". Os Estados e a comunidade internacional teriam, portanto, a 
responsabilidade de proteger as populações contra o genocídio, crimes de guerra, limpeza étnica e crimes contra a humanidade (del Prado, 2008)

Emergia, assim, a proposta de uma segurança que não tivesse mais o Estado como objeto referente, mas sim o "humano"66 e o foco da proteção se ampliaria a sete componentes: econômico, alimentar, saúde, meio-ambiente, segurança pessoal, segurança comunitária e segurança política.

Cristalizava-se, pois, o conceito de segurança humana como discurso que centralizaria as demandas políticas que revolvem o tema da paz no âmbito internacional. Como pode se observar no Relatório, um conjunto de diretrizes é estruturado com pretensões preventivas ou diagnósticas de disrupções à paz relacionando esta última ao desenvolvimento quase que de modo mutuamente exclusivo:

From such a diagnosis, it follows that the role of the United Nations must be strengthened significantly in the development field. The peace agenda and the development agenda must finally be integrated. Without peace, there may be no development. But without development, peace is threatened (HDR, 1994, p. iii).

For too long, security has been equated with the threats to a country's borders. For too long, nations have sought arms to protect their security. (...) For most people today, a feeling of insecurity arises more from worries about daily life than from the dread of a cataclysmic world event. Job security, income security, health security, environmental security, security from crime-these are the emerging concerns of human security all over the world (HDR, 1994, p. 03).

When the security of people is attacked in any corner of the world, all nations are likely to get involved. Famines, ethnic conflicts, social disintegration, terrorism, pollution and drug trafficking are no longer isolated events, confined within national borders. Their consequences travel the globe (HDR, 1994, p. 03)

It is less costly and more humane to meet these threats upstream rather than downstream, early rather than late. Short-term humanitarian assistance can never replace long-term development support (HDR, 1994, p. 03).

Embora o conceito da segurança humana pareça relativamente novo, ele surgiu incialmente como uma preocupação no ambiente familiar e posteriormente foi assimilado ao momento de surgimento e centralização dos Estados mediante o

\footnotetext{
${ }^{66}$ Destaca-se o papel do Centro Para Pesquisas de Paz e Conflitos da Escola de Copenhagen onde se formulou a Teoria da Securitização abriu e aprofundou do tema da segurança de modo a dar oportunidade para que questões de saúde pública, por exemplo, fossem levadas tão a sério quanto as políticas de Estado. Vide: "Buzan, Barry; Weaver, Ole; de Wilde, Jaap: Security: A New Framework for Analysis. London: Lynne Rienner, 1998”.
} 
desejo de distintos grupos de pessoas de garantir a sua própria segurança (Fell 2006 apud Ndlovu-Gatsheni \& Dzinesa, 2008). Posteriormente, o conceito entraria no mainstream dos estudos de segurança ganhando novas interpretações, tais como as indicadas no relatório do PNUD, isto é, seria tanto uma forma alternativa de segurança quanto uma forma de ampliação de seu escopo de modo a cobrir ameaças "não violentas" como doenças, fome e desastres naturais (Ndlovu-Gatsheni \& Dzinesa, 2008, p. 97).

O contexto da expansão do conceito de segurança foi um momento discursivo que também deu condição para que o conceito de segurança humana fosse importante para organizar em torno de si uma série de narrativas de proteção vocalizadas por atores privados tanto no âmbinto da cooperação para o desenvolvimento quanto por atores das operações de intervenção humanitária. Deste modo, a segurança enquanto referente para a humanidade como um todo se ressignificaria como forma de controle na política global.

Enquanto que nascia para atender as necessidades das populações em situação de conflito ou pobreza, a segurança humana tornou-se na voz de grupos como os dos Novos Humanitários um instrumento direcionado à arena da ordem pública. Mas o setor militar privado também não ficou de fora. Como aponta a Associação das Operações de Estabilidade Internacional (ISOA), todas as EMSPs membros do ISOA são obrigadas a assinar o código de conduta da associação se comprometendo com os esforços para causas como a da segurança humana, como pode ser observado abaixo:

All ISOA member companies subscribe to the ISOA Code of Conduct, which represents a constructive effort towards better regulating private sector operations in conflict and post-conflict environments and disaster relief. It reflects our belief that high standards will both benefit the industry and serve the greater causes of peace, development, and human security (ISOA, 2011).

Adicionamente, podemos encontar na revisão bi-anual do Código de Conduta do ISOA de 2011 outra referência do propósito das EMSPs membros da associação em relação à segurança humana como se pode observar abaixo:

This Code of Conduct seeks to establish consistent ethical standards for members of International Stability Operations Association operating in complex environments so that they may contribute their 
valuable services for the benefit of international peace and human security (ISOA, 2011, preâmbulo).

Observa-se que o compromisso do setor privado para com o significante da segurança humana não se limita às organizações de ajuda e alívio, mas também passam a fazer parte do vocabulário das EMSPs, num momento em que os militares privados tentam firmar seu espaço vis-à-vis aos atores humanitários no campo geral da discursividade humanitária.

MacFarlane \& Khong (2006) argumentam que o conceito de segurança humana "foi estendido para cobrir quase todo tipo de mal imaginável que afeta os seres humanos e, como tal, perdeu muito de sua tração analítica" (p. xiii). A interpretação conceitual se estirou, portanto, a ponto de se tornar um significante vazio quase que "por excelência" e a apropriação do termo no universo militar privado não seria tão inesperado quanto o foi no universo militar público.

Para Brekalo (2012), as EMSPs começaram a se engajar no campo da segurança humana por terem se tornado empreendedores normativos (norm entrepreneurs) e por serem capazes de moldar sua identidade de acordo com a expansão do mercado de modo a assegurarem sempre futuros contratos (p. 06). A comercialização da imagem das EMSPs com valores humanitários, seria tanto parte de uma adaptação às exigências dos clientes quanto uma internalização normativa institucional de modo a serem aceitos e evitarem problemas perante os analistas de segurança.

De certo que as EMSPs buscam ser identificadas como parceiras legítimas dos atores humanitários no campo e não apenas parte de um quadro contratual das operações humanitárias ao redor do mundo. Isso se percebe na extensão da membrezia e das atividades de pesquisa e publicação de organizações como o ISOA ou dos trabalhos de EMSPs independentes em parceiria com outras instituições e corporações.

No entanto, existe uma consequência política complexa no que tange à incorporação de discursos que implicam na (re)constiuição identitária de uma instituição: o problema da indiferenciação. Como apontam Fassin \& Pandolfi (2010), essa realidade tem levado a um número cada vez maior de beligerantes, como no Afeganistão, Chechênia, Siri Lanka e Sudão, a não mais fazerem distinção entre trabalhadores da ajuda humanitária e militares ditos 'humanitários' 
e desta forma resistem pela desconfiança em se estabelecer algum diálogo com estes. A proporção em que a mescla entre humanitários e militares tem tomado na ultima década preocupa um série outras ONGs, no entanto. A denúncia contra as EMSPs, particularmente, levanta maiores preocupações não apenas pela roupagem institucional com que estas se apresentam, mas inclusive a roupagem individual. A maior parte dos empregados terceirizados de empresas militares é facilmente confundível com um agente humanitário. A inserção das empresas em atividades culturais e sociais em locais considerados frágeis assusta não apenas pelos impactos que podem gerar nas atividades humanitárias orientadas por princípios, mas também pelos números.

Segundo o relatório do UN Working Group on Mercenaries os gastos com a contratação de EMSPs nos últimos anos é progressivo e com uma perspectiva de crescimento anual de 7.4 por cento (UN, 2013). Para o ano de 2016 se espera gastar a soma de \$244 bilhões em contratos ao longo do globo. Os EUA sozinhos gastam em torno de $\$ 138$ milhões e mesmo com a queda de 9 por cento dos gastos do Departamento de Defesa Americano nos últimos 5 anos físcais, os contratos com as empresas de segurança privada permaneceram estáveis, em torno de 26 milhões anuais entre 2009 e 2012 (UN, 2013).

O fortalecimento da indústria da segurança privada por meio de contratos não se dá, contudo, apenas pelos trabalhos geralmente conhecidos nos relatórios disponibilizados pelos governos contratantes e pelas próprias empresas, muitos dos serviços prestados são de natureza secreta e alguns resultados ou irregularidades só se tornam públicos quando há vazamentos ou vão parar em casos judiciais. Tão obscuro quanto os acertos destes contratos é o real custo envolvido nos programas. Segundo investigação feita em 2010 por Dana Priest e William M. Arkin, até então haviam 1.271 organizações governamentais e 1.931 empresas privadas, dentre estas as EMSPs, trabalhando em programas relacionados a contraterrorismo, segurança interna e inteligência em cerca de 10.000 locais somente nos Estados Unidos; além disso, cerca de 854 mil indivíduos possuíam autorizações de segurança ultrassecretas (Rock, 2014).

A crítica se estende obviamente aos números ainda maiores relacionados a programas fora do território americano. Em missões humanitárias e de desenvolvimento na África e Oriente Médio, por exemplo, se destaca a política 3D (defesa, diplomacia e desenvolvimento) dos EUA onde se concatenam 
interesses estratégicos e a lógica caritativa. A política 3D é o pilar, por exemplo, da campanha do AFRICOM que pretende expandir os trabalhos por meio de operações consideradas médias e de baixo custo no continente africano (Rock, 2014) $)^{67}$. O intrigante é como o discurso humanitário é introduzido como mecanismo de prevenção e gerenciamento das operações da AFRICOM. Enquanto que no Iraque as operações chamadas humanitárias teriam um caráter mais truculento, no continente Africano o discurso da segurança humana parece mais eminente. Para Joeva Rock (2014), operações militares com uma roupagem humanitária funcionam como Cavalos de Troia cujo objetivo é estabelecer pontos de entrada no continente no momento e lugar onde acham necessários. Ela cita inclusive como as coberturas jornalíticas elogiosas de especialistas premiados em assuntos de terrorismo e Segurança Nacional como Eric Schmitt contribuem para a causa humanitário-militar. Como observa,

[Eric] Schmitt wrote glowingly about fighting terrorism with mosquito nets: "Instead of launching American airstrikes or commando raids on militants," he wrote, "the latest joint mission between the nations involves something else entirely: American boxes of donated vitamins, prenatal medicines, and mosquito netting to combat malaria." But promoting AFRICOM as a humanitarian outfit is misleading at best (Rock, 2014, p. 2).

Rock (2014) relata como a AFRICOM, sob o auspício do desenvolvimento e da prevenção de conflitos, empreende regularmente projetos humanitários em países que não estão em situação de guerra permanente ou conflito. Como observa a autora, a AFRICOM depende fortemente de mídias sociais para mostrar esses projetos e a si mesmos como colaborativos com os parceiros africanos; mostramse dedicados à ajuda humanitária e confiáveis aos olhos dos povos locais, inclusive, por meio da utilização diária de sites de como Facebook e Twitter onde publicam frases de efeito publicitário, relatórios de missões médicas, imagens de tropas militares fazendo beneficências, e.g., na distribuição de brinquedos, etc.

As missões da AFRICOM e suas medidas para manterem próximas as relações com as populações locais, no entanto, se mostram tão expressivas quanto as estratégias dos novos humanitários em países de menor desenvolvimento.

\footnotetext{
${ }^{67}$ Ao contrário do objetivo, relatórios indicam que mais de uma missão é empreendida por dia no continente com um número de militares que vai de 5.000 a 8.000 militares norte-americanos em solo (Rock, 2014).
} 
Ainda que o objetivo das agências individuais seja cumprir com uma agenda considerada estritamente humanitária e de desenvolvimento, a associação financeira e contratual com militares públicos e privados não esconde a relação estrutural destes atores com as estratégias de contenção da influência, por exemplo, da China nos países africanos bem como da garantia de seguridade americana sobre novas fontes energéticas e recursos petrolíferos. Como explica Rock (2014),

(...) $[\mathrm{M}]$ any of AFRICOM's efforts are located in oil-rich regions specifically Kenya, Uganda, Ghana, and the Gulf of Guinea. In Takoradi, Ghana, for example - a place affectionately nicknamed "Oil City" - AFRICOM trains Ghanaian troops, conducts humanitarian missions, and meets with local chiefs, NGOs, and fishing communities (p. 3).

A preocupação, ademais, é que a mistura da ajuda humanitária com operações militares possa contribuir para a desconfiança pública local, confusão civil e para questões de transparência. Algumas agências, como o MSF, já têm exposto há alguns anos esta questão, principalmente quanto aos efeitos de longo prazo para as agências que se comprometem com a assistência humanitária de modo independente, sem associações com a política externa de outros estados ${ }^{68}$. Corroboram, portanto, com o que sustenta Rock (2014):

\begin{abstract}
Humanitarian projects allow military personnel to train in new environments, gather local experience and tactical data, and build diplomatic relations with host countries and communities. As activists with Women for Genuine Security have explained, this use of relief and humanitarian aid to "further larger geopolitical and military goals" - a practice they have dubbed "disaster militarism" is a general strategy employed by the U.S. military worldwide (p. 4).
\end{abstract}

A assimilação entre os universos militar e humanitário não é, contudo, desprovido de militâncias que resistem a esse discurso. Da parte das ONGs que desejam se manter o mais distantes possível das EMSPs humanitárias podem ser

\footnotetext{
${ }^{68}$ Vide Access to the Danger Zone (2012).
} 
encontrados trabalhos de conscientização ou publicidade alertando sobre as diferenças nas identidades institucionais ${ }^{69}$.

Oxfam e MSF, por exemplo, decidiram se posicionar não apenas contrariamente, mas espacialmente cada vez mais distantes não apenas das EMSPs, mas até mesmo de agências internacionais tais como o Alto Comissariado das Nações Unidas para Refugiados (ACNUR) e das forças armadas em geral (Fassin \& Pandolfi, 2010). Ainda que o ACNUR se apresente da mesma natureza dessas agências o receio é de que a proximidade com esta reflita a mesma acusação em relação às EMSPs, de que os atores humanitários obedecem a lógica dos jogos de poder entre os Estados e suas motivações imperialistas.

O fato é que a ação humanitária enquanto ganha centralidade nas relações internacionais também compõe normas que ganham força no discurso geral da guerra e da paz (Mills, 2005). Normas humanitárias que um dia legitimaram a presença de humanitários pela crença em sua independência política não são mais vistas como necessariamente invioláveis para angariar aceitação dos humanitários em campo. Em muitos casos se relata uma progressiva rejeição que, por vezes é um subproduto da associação percebida entre funcionários de ONGs e outros esforços políticos.

Acredita-se que o potencial para a associação entre ONGs e governos ou partes beligerantes tenha sido reforçada pela natureza cada vez mais global da violência uma vez que uma correta avaliação das condições locais não assegura contra o alvejamento por parte de grupos afiliados de fora (Avant, 2007b). Essa consciência de que existe uma instrumentalização da ajuda humanitária teria ocorrido de duas formas. No primeiro momento, houve o conhecimento de que a ajuda humanitária era muitas vezes desviada para apoiar combatentes, e num segundo momento, percebia-se que a linguagem humanitária era adotada por militares e governos, o que levou a uma indefinição das fronteiras entre a ação que era unicamente humanitária e a que estava ligada a objetivos políticos (Avant, 2007b, p. 149).

Nos casos em que as associações envolvem empresas multinacionais que investem e extraem recursos indispensáveis às economias do Norte, podem-se

\footnotetext{
${ }^{69}$ Vide Access to the Danger Zone (2012), onde o MSF reserva um momento para tratar do
} assunto. 
encontrar documentos como os Princípios Voluntários formulados por meio de negociações entre as corporações transnacionais, ONGs e governos como os EUA e o Reino Unido, que influenciam na orientação das decisões de segurança das corporações transnacionais que trabalham em territórios considerados instáveis. Os documentos que resultam dessas negociações sugerem atenção às avaliações de risco, consciência da situação de segurança antes de se "investir em um território, e uma série de consultas com o país anfitrião tanto para avaliar o impacto da empresa quanto para comunicar os padrões internacionais necessários (incluindo a transparência e a participação dos cidadãos) que a empresa deseja que o governo siga" (Avant, 2007b, p. 155).

Sugere-se que as empresas com negócios nos países instáveis façam uso de sua influência para promover a adesão ao direito internacional aplicável, observa Avant (2007b), e no caso de um governo não poder oferecer segurança e alguma empresa transnacional resolva contratar uma EMSP para proteção local, as diretrizes sugerem que se garanta que a "EMSP irá observar a política da empresa, manter a competência profissional adequada e agir de forma legal, observar regras de engajamento e conduzir apenas medidas preventivas ou de segurança defensiva". Além disso, resguarda-se que os militares privados sejam selecionados de modo cuidadoso, particularmente quanto a recordes de abusos de direitos humanos (p. 155) ${ }^{70}$. Temos, assim, um panorama de transformação do entendimento da noção de segurança que é cada vez mais dependente da interação de princípios compartilhados entre os atores estatais e não estatais e objetivos corporativos em campo. Como bem coloca Avant (2007b):

Securitization scholars were deft at describing the traditional notions of security, its association with states, and the benefits that states would enjoy in security discourse, but they did not predict that nonstate actors, precisely because they could not legitimately make the same claims as states in the security arena, might speak of security in

\footnotetext{
${ }^{70} \mathrm{~A}$ empresa Shell foi uma das grandes empresas que adotou o chamado "Voluntary Principles on Security and Human Rights" numa tentativa de melhorar sua imagem depois do escândalo envolvendo a morte de um ativista ambiental na Nigéria. Saro-Wiwa, que fundou o Movimento para a Sobrevivência do Povo Ogoni em 1990, foi um dos críticos mais contundentes da Shell por causa dos danos causados às comunidades do delta, incluindo a queima de gás e a destruição de manguezais para dar lugar a oleodutos (Mouawad, 2009). Ele foi enforcado pelo regime militar daquele país depois de protestar contra as práticas ambientais da empresa que tinha ligações com o governo. A adoção de diretrizes e o aumento do contrato de EMSPs para proteção corporativa se deu, portanto, tanto como resultado de esforços de ONGs e outros grupos interessados em educá-los quanto a uma crença compartilhada entre os funcionários da Shell de que a rentabilidade de longo prazo da empresa demandaria assumir alguma responsabilidade pela forma com que a governança é feita em estados fracos (Avant, 2007b).
} 
different ways and open the way for the transformation of its meaning (p. 157).

Se por um lado, as atividades de ONGs voltadas à ajuda ${ }^{71}$ ao desenvolvimento se estende a trabalhos de ajuda humanitária, por outro lado, temos a expansão de organizações humanitárias para práticas antes reconhecidas no escopo das atividades de desenvolvimento; isto é, não emergenciais, como visto no capítulo 2.

Quando se observa a história de crescimento de organizações como o MSF, por exemplo, temos um quadro progressivo de atividades diretamente proporcional às novas preocupações surgidas em países com situações precárias de saúde e subsistência. No início dos anos 1990, o MSF havia alcançado o objetivo de melhorar seu sistema logístico global e se tornaram mais proficientes tecnicamente (Redfield, 2010). No entanto, crises humanitárias que requeriam uma maior reflexão sobre os reais objetivos do grupo, levaram-lhes a buscar algumas reformulações. Como observa, Redfield (2010), ao contrário da Cruz Vermelha, o MSF não tinha mandato específico ou estatuto jurídico para além do seu regimento interno e artigos de incorporação. O trabalho médico era voltado sobretudo para impedir grandes eclosões de doenças e aliviar no curto prazo os efeitos nefastos dos destrates ocorridos. Contudo, era quase que inevitável a reflexão sobre a posição moral do MSF em relação a denunciar ou não o que assistiam. As críticas foram inevitáveis à medida que a estrutura organizacional buscava novas iniciativas. Além disso, eram liderados por um arranjo de pessoal em constante mudança.

A expansão do trabalho do MSF, no entanto, se depararia com muitas iniciativas frustradas ou que provariam curta duração. Em algumas ocasiões ou o MSF murcharia devido à saída de visionários chaves ou seriam eclipsados pelos acontecimentos. Entretanto, isso não viria impedir que, com o tempo, o MSF viesse a patrocinar missões muito além da resposta de emergência clássica para guerras ou desastres naturais. Práticas que estão mais presentes no escopo de agências de desenvolvimento, i.e., aquelas que se preocupam com o longo prazo passariam a fazer parte do escopo de ação do MSF. "Apesar de as emergências continuarem a definir a sensibilidade e o perfil público do grupo", observa ${ }^{71} \mathrm{Ou}$ "cooperação ao desenvolvimento", como preferem alguns, em vez de "ajuda ao desenvolvimento". 
Redfield (2010), "sua definição do que constitui uma crise se expandiu para incluir problemas como HIV-AIDS e saúde mental, condições improváveis de se resolver de forma certeira ou conclusiva" (p. 177).

No que diz respeito a questão da segurança individual da equipe, o grupo dos MSF percebia a vulnerabilidade com que se encontravam e assistia o modo com que outras organizações respondiam à situação - contratando proteção armada e privada, por exemplo - de forma preocupante. Segundo reportado no relatório (Activity Report) do MSF de 2004, durante um período de tempo o grupo reconheceu uma série de desafios significativos tais como o aumento do humanitarismo militar - que o grupo responsabilizara pela perda de cinco funcionários no Afeganistão -, e a necessidade de recuperação de gastos com saúde internacional e o desastre emergente em Darfur, para o qual o MSF respondeu com uma grande operação e repentina publicidade, muito perto de se denunciar como genocídio. O relatório também destacou uma série de questões regionais relacionadas com o vírus do HIV na África, e outras doenças como a tuberculose na Ásia, bem como a situação dos imigrantes recentes na Europa (Redfield, 2010, p. 177).

Como se vê, a postura do MSF durante a reflexão sobre a necessidade de uma extensão da ajuda emergencial à assistência mais de longo prazo não foi o mesmo tipo de extensão ocorrido em organizações não governamentais que trabalham com agendas humanitárias não emergenciais. ONGs que não são independentes de agendas de política externa de outros países adotam a necessidade de ajuda não emergencial como um dever não necessariamente moral, mas como dever de contrato. Os doadores internacionais e os funcionários de organizações deste tipo entendem que a proteção dos trabalhadores e dos recursos em campo devem ser resguardados acima de tudo, o que facilita o firmamento de acordos de proteção entre novos humanitários e EMSPs. A contradição, no entanto, é que ONGs de novos humanitários que supostamente se preocupam com a situação de longo prazo dos países pobres acabam por minar a aceitação de grupos beligerantes que progressivamente rejeitam a presença de militares junto à assistência humanitária. A desconfiança mútua e a dificuldade de todos os grupos definirem o que afinal é um humanitário vai retardando a eficácia da assistência de grupos mais tradicionais que acreditam ser independentes da lógica de mercado e dos objetivos políticos e corporativos envolvidos nas ricas 
terras africanas onde se insiste em catalogar-se como lugar de necessidade e pobreza.

O cenário de pobreza, emergência e vulnerabilidade vai fortalecendo a linguagem que percebe o excesso de carência como o lugar da ausência; ausência de proteção generalizada. Esse lugar de periculosidade é complexo e inseguro o suficiente para se poder esperar qualquer emergência, no sentido de que algum mal pode emergir a qualquer momento. Emergência complexa e (in)segurança humana são rótulos, portanto, explicativos da necessidade de operações mais bem programadas, distributivas, seguras para entrega de assistência humanitária.

As EMSPs ainda permanecem fornecendo logística suplementar e segurança para o pessoal das organizações humanitárias confrontadas com tais situações de emergência complexa e as missões são reportadas como cada vez mais perigosas. No novo contexto normativo em formação, os discursos da segurança humana se tornam gramática comum no entendimento dos atores humanitários e a apropriação explícita ou subentendida dessa gramática por parte das empresas privadas formalizam os contornos do quadro humanitário do início do século XXI. Enfatizando os elementos que se encaixam aos seus interesses e necessidades, as EMSPs se apresentam como “outros humanitários”, mas também "novos humanitários", uma alternativa extra dentre as já estabelecidas alternativas.

Joachim \& Schneiker (2012) acreditam que as EMSPs empregam basicamente dois tipos de estratégia no campo do humanitarismo contemporâneo. Por um lado, as empresas nomeiam e, por outro, forjam alianças com outros atores humanitários mais tradicionais e, como resultado, o envolvimento crescente neste campo não fica sem consequências tanto para humanitários quanto para as populações locais receptoras da assistência, o que contribui para obscurecer as fronteiras entre missões militares e civis.

A complexidade em questão forja as relações dos atores humanitários com as novas situações de segurança e permite que o conceito de "segurança humana" se estabeleça como condição sine qua non para o avanço das melhorias nos países em condição de vulnerabilidade. Como observa Joachim \& Schneiker (2012): 
Instead, the security of the individual and of societal groups has gained importance, accompanied by attention to threats other than military attack, such as environmental pollution, pandemics and poverty. Consequently, aid plays an increasing role in stabilization and peacekeeping efforts within situations of so-called 'complex emergencies' and multidimensional responses such as 'integrated missions' (p.373).

Além disso, os autores observam que a ajuda humanitária faz cada vez mais parte de estratégias políticas e militares como as de 'Contrainsurgência' (COIN). Ao contrário da visão das forças armadas ${ }^{72}$, "as operações de COIN são acima de tudo uma luta política e não apenas um confronto propriamente militar. A batalha é para o apoio ou controle do povo. Quem domina o povo é quem ganha a guerra" (Joachim \& Schneiker, 2012, p. 373). Em Cabul, por exemplo, o MSF acredita que as operações de COIN estão diretamente ligadas às decisões das organizações ocidentais sobre quais áreas terão direito de receber ajuda humanitária. Segundo Michel Hofman (MSF, 2010), chega-se a referir à situação como "circo humanitário", pois embora houvesse até então em torno de 1800 ONGs e agências da ONU no Afeganistão, pouca assistência estava sendo provida para a população de Cabul. Isso se explicaria pelo fato de, na lógica de contrainsurgência, a ajuda vir, tradicionalmente, de nações ocidentais e seguir a lógica militar das tropas ocidentais. Como observa:

The result is that aid money from any given country tends to go where their troops are based. Kabul does not have a large presence of Western troops, as it is not the focus of the conflict. As a result, NGOs and UN agencies, most of whom depend on funds from the West, do not have the finances to implement programs for the people here. This is why MSF decided to work in Kabul, in order to address the needs of the most vulnerable groups, such as displaced people and returnees (MSF, 2010).

Para Joachim \& Schneiker (2012), as operações de COIN são trabalhos sociais armados que visam ganhar corações e mentes das populações locais, uma vez que os militares estão envolvidos na entrega de assistência humanitária diretamente ou indiretamente quando transferem a tarefa para as agências

\footnotetext{
${ }^{72}$ Segundo a definição do ADRP 3-07 (2012) do exercito americano, "contrainsurgência consiste em esforços civis e militares abrangentes tomados para derrotar uma insurgência e resolver quaisquer queixas principais. Na contrainsurgência, as forças da nação anfitriã e seus parceiros operaram para derrotar a resistência armada, reduzir a oposição passiva e estabelecer ou restabelecer a legitimidade do governo do país em questão. O método de Contrainsurgência foi a operação conjunta dominante nas Operações Iraqi Freedom e Enduring Freedom" (p. 17).
} 
humanitárias (p. 373). Por estas e outras razões, muitos analistas começaram a indicar o vazio conceitual que tem adquirido o sentido da palavra "humanitário" e ressaltam que atores como as EMSPs "não apenas desafiam o monopólio que até então era desfrutado pelas ONGs, mas também passam a competir com elas para (re)definir a identidade humanitária” (p. 374). Assim como mencionado anteriormente, o que ocorre no campo geral da discursividade humanitária é um processo articulatório que equivale o discurso das EMSPs ao discurso humanitário. Joachim \& Schneiker (2012) propõem que o fenômeno se trata de uma apropriação de um quadro discursivo antes presente no discurso do novo humanitarismo, mas que vai se adequando às necessidades e interesses das empresas militares ou de segurança privada. Como observam:

These observed changes are an indication that " $[t]$ he very meaning of humanitarianism bas become elusive'. The 'traditional' neutral, independent and impartial not-for-profit humanitarian actors no longer 'own' the humanitarian frame. Because the humanitarian frame is undergoing change, it allows for different interpretations: humanitarianism can be more or less neutral, independent and impartial, but also political; it can be carried out by state and/or nonstate actors, by non-profit and/or for-profit organisations; and it can comprise a variety of services ranging from emergency relief to long-term assistance (Joachim \& Schneiker, 2012, p. 374).

Deste modo, a convergência de discursos em operação foi trabalhada dentro de um processo de oportunidades de agência muito maiores, ou seja, o processo de agenciamento das EMSPs não se deu ex nihilo, mas foi manejado a partir de condições discursivas envoltas nos processos políticos e econômicos dos anos 1990, como observado ao longo dos capítulos anteriores, mas outras condições de existência ainda podem ser consideras, uma investigação do capítulo a seguir. 


\section{Mesclando forças}

\subsection{As oportunidades para as EMSPs}

Dentro do campo da discursividade humanitária, como já visto, as EMSPs adequaram seus objetivos comerciais à sua capacidade de prover serviços multidimensionais com alta eficiência. E a multidisciplinaridade das EMSPs se compatibilizou facilmente com a lógica de segurança após o fim da Guerra Fria, principalmente, pela mescla de diferentes vocabulários onde não apenas se encontram elementos antes limitados à esfera do trabalho humanitário, mas também, uma grande difusão do vocabulário do desenvolvimento (Duffield, 2001). Para o propósito desta seção, vamos considerar os argumentos de que o crescimento e expansão das EMSPs coincide, de um lado, com o aumento da demanda de segurança por parte das agências humanitárias e de desenvolvimento e, de outro, coincide com o fato de humanitários e agentes de desenvolvimento optarem por vezes em se retirar do campo em vez de recorrerem a métodos alternativos de segurança para fornecer ajuda e assistência em ambientes considerados inseguros (Guidero, 2012). Estas circunstâncias são oportunidades discursivas que harmonizaram o ímpeto internacional para construção da paz em países considerados pobres e afetados por conflitos com a disposição das EMSPs para entrar em um negócio bilionário de práticas multidisciplinares.

Na conferência de 2008 da ISOA o chefe do setor da Divisão de Guerra Irregular das Operações de Estabilidade no Pentágono, o tenente-coronel James Boozell, faz uma observação importante para compreendermos as justificativas que estão em jogo. De acordo com o tenente, “em conjunto com um esforço humanitário, deve-se ter uma parte desenvolvimentista para ensiná-los (referindose a 'Estados fracos') a sobreviver por conta própria" (Valero, 2008). Este é um exemplo da lógica sendo disseminada desde a década de 1990, onde os esforços de segurança e desenvolvimento se casariam ao vocabulário das atividades humanitárias para formar uma tríade que é fundamental para visualizar como o discurso da proteção pode ser mobilizado no complexo cenário do pós Guerra Fria.

A adequação de certas características geralmente encontradas na ação humanitária ao circuito da segurança pode receber interpretações de várias 
esferas, seja política, estratégica, econômica ou mesmo moral. No entanto, as práticas das EMSPs ainda estão muito identificadas ao mercenarismo em situações de conflito, o que levanta preocupações de diferentes organizações ao alegarem que as lógicas do lucro e da humanidade não estão em sintonia. O relatório da Comissão de Direitos Humanos (CDH) de 2005 afirma que:

Certain experts raised concerns that the regulation of private companies could lead to further legitimization of the trend towards private security (...) and that the primary motive of PSCs was profit, not humanitarian in nature and that humanitarian activities often provided a cloak of legitimacy for otherwise doubtful activities (CHR, 2005: §97).

Até agora, as EMSPs estão bem estabelecidas no que elas chamam de “operações humanitárias" e sua regulamentação está a caminho uma vez que enormes esforços estão sendo feitos em termos jurídicos. Recentes tipos de regulações tais como códigos de boa conduta e obrigações éticas foram liberados em documentos como: UN Working Group on mercenaries (2005), Montreux Document (2008), The Global Code of Conduct for Private Security Companies and Private Military Companies (2010), Good Practice Review [Operational Security Management in Violent Environments, 2010], International Code of Conduct for Private Security Service Providers (2012), e assim por diante. Outro documento relevante é o Relatório HPG de número 27 de 2008 que teve como objetivo mapear a prática atual e as tendências contratuais no que diz respeito aos interesses humanitários e a aproximação da indústria de segurança privada em direção a estes.

Leander (2005) afirma que é difícil imaginar um mecanismo que impeça uma dessas empresas de satisfazer demandas consideradas “ilegítimas”, não só porque contar com a autorregularão através do mercado é problemático, mas também porque trabalhar com clientes ilegítimos não é necessariamente uma desvantagem para elas. Além disso, ela afirma que:

For many PMCs, it is unimportant whether or not the market sanctions working for illegal contracts. Some firms will make one operation and then withdraw. This is a viable strategy as the markets are fluid. Firms are created, dissolved, branched, merged and moved from one location to another, and hence can be very difficult to trace (Leander, 2005, p. 614). 
Spearin (2003), por um lado, considera a interação entre EMSPs e humanitários uma consequência não apenas da natureza financeiramente lucrativa do relacionamento, mas também porque a questão humanitária pode dar legitimidade ao setor de segurança comercial através do fazer aparente de "boas obras". Por outro lado, ele considera essa uma questão política muito importante: as organizações humanitárias têm se voltado para as EMSPs em resposta às restrições do ambiente humanitário no pós Guerra Fria. $\mathrm{O}$ autor não esclarece o que considera como restrições, mas podemos inferir que pode referir-se ao que Leander (2010) chama de "dividendo da paz" do fim da Guerra Fria quando a esperada redução das despesas militares foi "canalizada para o mercado emergente e o manteve crescente" (p. 209).

O que é importante ter em mente a partir deste contexto é que ocorre uma gradual e significativa abertura a novos atores, neste caso das agências de segurança, para moldar o significado do humanitarismo e das práticas de segurança através de sua capacidade de transformar o vocabulário das situações de emergência. Manejar o discurso da proteção em termos humanitários já foi tradicionalmente entendido em termos de sua relação com a realidade de sociedades dilaceradas por conflitos militares, mais tarde, no entanto, seria interligado a uma vasta lista de elementos que têm de ser preservados.

Jef Huysmans (2006) chama a atenção para esta questão por meio da concomitante abertura da agenda de segurança nos anos 1990. Ele afirma que no processo de ampliação da agenda de segurança as áreas mais visíveis em que as questões importantes eram levantadas foram as reivindicações de segurança ambiental e reivindicações de segurança na área de políticas de imigração e de refugiados. Ao trazer as "ameaças não militares" ao conhecimento de todos e ao incluir objetos referentes não-estatais abriu-se a questão da agência política. Como uma questão política, atores diferentes e poderosos entraram na arena para competir ou contestar o que deve ser protegido e quem está autorizado a proteger. As EMSPs neste contexto não são simplesmente os empreiteiros que ajudam os responsáveis pela "política de proteção", mas são também produtores de suas próprias demandas no jogo político. Como afirmado por Huysmans (2006): 
The notion of a 'politics of protection' emphasises this politically contested nature of claims of protection and insecurity, both in terms of their legitimacy and the techniques of administering them. Claims of protection are not simply constructed through discourse and bureaucratic routine but remain embedded in fields of contestation structured by power relations between participating agencies (p. 5).

O aumento da terceirização e da privatização, como coloca Leander (2006, p. 19), "significa que as empresas privadas estão muitas vezes em condições de definir diretamente as questões de segurança, pois a tarefa de fazê-lo tem sido diretamente terceirizada". Isso significa que, por vezes, o propósito de alguns contratos é de fato deixar às EMSPs a função de definir as ameaças e decidir como lidar com elas. Publicações divulgadas em sites de EMSPs são muito sugestivas sobre este assunto. Não é raro encontrar o termo proteção ligado à proteção de pessoas e objetos em "ambientes de alto risco". Justificativas estão normalmente relacionadas à garantia de que os atores legítimos sejam capazes de exercer o controle em "espaços subgovernados". Serviços de inteligência privada e outras atividades relacionadas são exemplificativos das pré-classificações feitas por EMSPs e "mesmo quando as categorias são definidas em colaboração com as Forças Armadas ou Ministério das Relações Exteriores e autoridades de segurança, as empresas filtram quais informações são relevantes e as que não são" (Leander, 2006, p 22.). O trabalho com fim lucrativo pode, portanto, não casar bem com ameaças não-lucrativas.

\subsection{Dicursos meta-orientados: proteção, prevenção e multidimensionalidade humanitária}

O uso do vocabulário da proteção parece estar gradualmente interligando-se às metodologias de prevenção. Durante 35th Round Table on Current Issues of International Humanitarian Law, realizada em San Remo em setembro de 2012, a narrativa para construir um sistema credível para responsabilização dos prestadores de serviços de segurança privada sustentou-se na necessidade de "proteger a segurança, a incolumidade e os direitos não só das comunidades locais e impactadas, mas também dos clientes e dos provedores de serviços de segurança" por meio do "monitoramento situacional" e "avaliação de risco", onde 
destacam-se a "antecipação e a prevenção de eventos indesejáveis e perturbadores" (Siegel, 2012).

Em zonas de conflito, os contratos de agências humanitárias e outras organizações internacionais podem estipular a prevenção como um método garantido através de técnicas de vigilância. A justificativa seria a necessidade de operar os riscos de atos agressivos (sequestros, assassinatos, etc.) contra as organizações humanitárias, funcionários das representações diplomáticas ou pessoas de negócios privados. O Relatório do Conselho Federal Suíço sobre as Empresas Militares e de Segurança Privada (Swiss Federal Council Report, 2005) menciona o termo vigilância como uma tarefa que faz parte da própria definição do negócio. Notavelmente, eles separam os provedores de segurança em duas categorias distintas: as Empresas de Segurança Privada (ESPs) e as Empresas Militares Privadas (EMPs). As ESPs são "um negócio cujo objetivo é fazer lucro pelo fornecimento de bens ou serviços para a proteção e para a guarda e vigilância de pessoas e bens", as EMPs são um "negócio cujo objetivo é fazer lucro pela prestação de serviços militares nas áreas de consultoria, logística e combate”. O problema é que as grandes corporações muitas vezes não se limitam a um ou outro conjunto de serviços. Este mesmo documento levanta uma questão importante no que diz respeito à permissibilidade das atividades privadas na área de segurança.

Should private security personnel have the right to check private individuals, to detain them and handcuff them if necessary, to frisk them or to confiscate items from them, or should their powers be restricted to protection and surveillance activities, maintaining public order and preventing unlawful encroachments? (p. 24).

Embora a resposta esteja relacionada às pessoas do território da Suíça ela ajuda a refletir sobre a dificuldade de se tratar dessas empresas como tendo um lugar preciso na dicotomia público versus privado. De acordo com o relatório, as intervenções nos direitos individuais são permitidas dependendo de quão autorizadas estas empresas estão "a fim de manterem a segurança e a ordem pública e usar a força, se necessário" o que também "depende em parte se a intervenção em questão se verifica em um espaço público ou privado". O documento em seguida retoma o que eles entendem por esferas públicas, privadas 
e semipúblicas que não são muito úteis se tomarmos a sociedade suíça como um modelo para o resto do mundo onde as EMSPs estão fortemente atuando.

No que tange à multidimensionalidade dessas empresas, sua capacidade de operar tarefas humanitárias em qualquer lugar do mundo de modo eficiente entra dos moldes discursivos da prevenção e da proteção, relacionados com a tríade segurança, desenvolvimento e humanitarismo. Como visto capítulo anterior, a prevenção de distúrbios à paz é feita pela promoção dos componentes da segurança humana. Como exemplo, a tabela 01 resume quatro casos em que empreiteiras privadas conhecidas por seus serviços militares desempenham estas funções. As descrições são narrativas extraídas diretamente dos encartes online das empresas.

\begin{tabular}{|c|c|}
\hline Aegis $^{73}$ & Sterling Global Operations ${ }^{74}$ (EODT) \\
\hline $\begin{array}{l}\text { - Suporte médico, logístico, Neutralização de } \\
\text { Artefatos Explosivos (NAE), apoio humanitário e } \\
\text { assistência de socorro em desastres; } \\
\text { - Educação em Direitos Humanos e Direito no } \\
\text { Conflito Armado e Reforma do Setor de Segurança; } \\
\text { - Monitoramento de Eleições; } \\
\text { - Apoio Logístico; } \\
\text { - Desmobilização, Desarmamento e } \\
\text { Reabilitação (DDR). }\end{array}$ & $\begin{array}{l}\text { - Segurança; } \\
\text { - Desminagem; } \\
\text { - Remoção e ação reparadora que aborde sobre a segurança, } \\
\text { a saúde humana e os riscos ambientais apresentados por } \\
\text { artefatos explosivos não detonados (AEND). } \\
\text { - Apoiar a exploração de energia e desenvolvimento em áreas } \\
\text { remotas e subdesenvolvidas do mundo } \\
\text { - Soluções de comunicação. }\end{array}$ \\
\hline DynCorp International $^{75}$ & $\mathrm{KBR}^{76}$ \\
\hline $\begin{array}{l}\text { - Logística humanitária e mercadorias de socorro } \\
\text { (entrega de suprimentos humanitários críticos para } \\
\text { a população local, etc.); } \\
\text { - Abrigo humanitário e proteção (proteção física de } \\
\text { pessoas deslocadas internas, refugiados ou em } \\
\text { emergência); } \\
\text { - WASH (construção de poços e latrinas e a } \\
\text { promoção do uso seguro da água, higiene das } \\
\text { mãos e saneamento saudável, etc.). }\end{array}$ & $\begin{array}{l}\text { - Resposta imediata a ataques terroristas, desastres naturais, } \\
\text { explosões imprevistas; } \\
\text { - Assistência humanitária } \\
\text { - Construção/reparação de aeródromo, cais, plantas de energia } \\
\text { elétrica, sistemas de distribuição, estações de tratamento de } \\
\text { água, pontes, unidades de armazenagem, clínicas médicas, } \\
\text { cercas e instalações similares. }\end{array}$ \\
\hline
\end{tabular}

\section{Tabela 01: Atividades das EMSPs}

\footnotetext{
${ }^{73}$ Fonte: http://www.aegisworld.com/index.php/humanitarian-support-services-2. (Acesso em: 02 Ago. 2013). Nesta página Aegis explica, por exemplo, que seu objetivo no Iraque estava relacionado "com a provisão de um quadro de segurança que permitisse o referendo constitucional do Iraque e as eleições gerais programadas para ocorrerem sem impedimento do ambiente de segurança e permitir que a democracia prevaleça". Em outra página (http://www.aegisworld.com/index.php/new2/security-operations-2/humanitarian-support-services2/humanitarian-support-services-case-study-2) aponta-se que se fará "o que quer que tenha que ser feito para assegurar que o sucesso do processo eleitoral democrático aconteça dentro dos limites do quadro regulatório". (Acesso em: 02 Ago. 2013).

${ }^{74}$ Fonte: http://www.sterlinggo.com/capabilities/overview/. Sterling Global Operations se fundiu com a EODT, mas algumas subsidiárias ainda mantêm o nome antigo; (Acesso em: 02 Ago. 2013).

${ }^{75}$ Fonte: http://www.dyn-intl.com/media/277/development_brochure.pdf e http://www.diatworknow.com/development/di-development-delivering-solutions; (Acesso em: 02 Ago. 2013).

76 Kellogg, Brown \& Root Services Inc. Fonte: http://www.kbr.com/Markets/Government-andDefense/Facility-Design-and-Construction/Rapid-Response/ http://www.kbr.com/Newsroom/Press-Releases/2013/08/12/KBR-Awarded-US-Navy-GlobalContingency-Construction-Contract/. (Acesso em: 04 fev. 2014).
} 
Para citar mais alguns exemplos, o ArmorGroup (parte do Grupo G4S), empresa com muitos contratos com o governo americano e alguns processos judiciais feitos a público ${ }^{77}$ passou em 2005 a empreender trabalhos não apenas como Reformas do Setor de Segurança $\left(\mathrm{SSR}^{78}\right)$ e Desarmamento, Desmobilização e Reintegração (DDR), mas também reconstrução pós-conflito (Østensen, 2011). Outra EMSP relevante é o MPRI, amplamente conhecido por suas capacidades de treinamento militar, mas que em 2005 passou a trabalhar com manutenção da paz e ajuda humanitária atuando agora em "Programas de Assistência à Transição Democrática", formação em direitos humanos, gestão de recursos naturais, entre outros (Østensen, 2011).

Empresas como o ICI (International Charter Incorporated of Oregon) são mais específicas e simbolicamente apelativas como pode se perceber nas imagens disponibilizadas em seu site que praticamente se confudiriam com sites de agências humanitarias tradicionais ${ }^{79}$. Como apresentado pelo ICI, os trabalhos que proveram, por exemplo, em 2000 na Nigéria na operação Focus Relief foram variados:

\begin{abstract}
At the conclusion of the mission in Nigeria, ICI (International Charter Incorporated of Oregon) had provided multiple life saving emergency evacuations, humanitarian relief operations, immediate response logistical support, VIP security protection, and emergency contingency missions that far exceeded the initial scope of the project. Safety, flexibility and professionalism were the cornerstones of mission success for ICI of Oregon in Nigeria (ICI, 2000a).
\end{abstract}

E no Sudão, a US Public Law 106-426 disponibilizou para o ICI Foundation Project cerca de US\$ 10 milhões em recursos para prestarem assistência à Aliança Nacional Democrática do Sudão que se opunha ao regime islâmico de Cartum. A ajuda humanitária fornecida incluia:

(...) non-lethal assistance to the NDA, such as blankets, medicine, fuel, mobile clinics, water equipment, communications equipment to notify civilians of aerial bombardment, non-military vehicles and tents. (...) The medical personnel trained were to be placed in the

\footnotetext{
${ }^{77}$ Vide, por exemplo: http://www.globalresearch.ca/the-privatization-of-war-mercenaries-privatemilitary-and-security-companies-pmsc/21826 ou http://www.dailyrecord.co.uk/news/scottishnews/g4s-aware-crucial-screening- failures-3615814 ${ }^{78}$ Do inglês Security Sector Reform.

${ }^{79}$ Vide: http://www.icioregon.com/Sudan2.htm; http://www.icioregon.com/Sudan3.htm
} 
forward areas in order to provide medical attention to both civilian and military wounded regardless of affiliation (ICI, 2000b).

O "empoderamento" que pode ser dado às EMSPs para intervir em situações consideradas pelos tomadores de decisão como arriscadas e perigosas é, no entanto, problemático não apenas do ponto de vista do controle, vigilância e interferência dos direitos privados. A questão do trabalho com fins lucrativos das EMSPs levanta preocupações sobre como é possível que os direitos de proteger e prevenir eventos disruptivos sejam dados a quem tem registros de desrespeito aos direitos humanos ou má reputação na observância dos direitos civis já que muitos dos provedores da segurança humana possuem um registro grande de desrespeito aos direitos humanos.

DynCorp, por exemplo, é uma empresa que está gradualmente especializando-se em uma grande quantidade de serviços exigidos na maioria das operações em todo o mundo. A diversificação das funções em contratos terceirizados, no entanto, pode ser muito contraditória já que o mesmo empregador, que fornece ajuda humanitária em um lugar pode ser o único que treina pessoas para serem atiradores profissionais em outros lugares. Cotrabalhadores da DynCorp (e funcionários das Nações Unidas), por exemplo, foram acusados por Kathryn Bolkovac (à época contratada como força-tarefa da polícia) por tráfico de humanos na Bósnia-Herzegovina em 2002 (POGO, 2002). Eles também foram acusados de ajudar um programa apoiado pelos americanos para o exército bósnio uma vez que os agentes da CIA admitiram ajudar a treinar o Exército de Libertação do Kosovo (KLA) antes do bombardeio da OTAN na Iugoslávia em 1999. Naquela época a CIA estava trabalhando em grande parte através de empresas do setor corporativo tais como o Military Professional Resources Inc. (MPRI) e a DynCorp (Walker \& Laverty, 2000).

Se a utilização de EMSPs crescia desde a Primeira Guerra do Golfo, onde a proporção de soldados e mercenários era respectivamente 50:1, durante o conflito na Bósnia entre 1992-1995 a proporção subiu para 10:1. Já no governo de George W. Bush, segundo Avant (2002), a decisão de se fazer um maior uso de EMSPs na "guerra contra o terror" se deu ao sucesso de empresas tais como o MPRI e DynCorp em décadas anteriores. Considerou-se que estas empresas tiveram um bom desempenho no treinamento de forças húngaras e que seria viável trazê-los 
até os padrões da OTAN, mais uma vez na preparação de forças Croácia e na Bósnia para lutar contra os sérvios em 1995, na Colômbia, para participar em missões de combate às drogas, e na África em vários treinamentos em missões militares (Hellinger, 2004, p. 194).

No caso da KBR, subsidiária da Halliburton até 2007, há uma série de processos contra a empresa relacionados a superfaturamento de produtos, contaminação de água e irregularidade sanitária no Iraque ${ }^{80}$, descaso para com a segurança de trabalhadores logísticos ${ }^{81}$, etc. Um dado relevante é na época em que houve uma redução do número de militares nos anos 1990, o então secretário da Defesa americano, Dick Cheney, que contratara a Halliburton para consultoria, veio a se tornar mais tarde o presidente da empresa ${ }^{82}$. A KBR é uma das maiores receptoras de contratos com o governo dos EUA para as operações militares muitas vezes chamadas humanitárias (Thürer, 2011, p. 255).

A discussão ética que vem de serviços paradoxais como os das EMSPs também está imbricada na preocupação com a terceirização e privatização da inteligência. $\mathrm{O}$ controle de informações sobre um território, pessoas e movimentos nas mãos de EMSPs correm o risco de serem filtradas de acordo com seus próprios interesses privados. Como ressalta Leander (2006):

They shape how others who partake in the politics of protection think of their own interests in the field. The firms directly push for specific interpretations and more subtly train and educate others to shape their understanding of the matter. PMCs shape how information is understood by lobbying decision-makers at different levels, trying to get them to adopt an interpretation of facts, which corresponds to the interests of the firms (p. 23).

Mesmo se forem as autoridades públicas as que estiverem executando a decisão final em uma operação, para Leander (2006) isso pouco importaria uma vez que são as EMSPs as que controlam o que o setor público pode ou não saber. Como observa a autora, a decisão se um governo, um movimento político ou uma pessoa é uma ameaça deve ser analisada por fontes de informação concorrentes. A oportunidade que se dá a diferentes fontes de informação, tais como governos,

\footnotetext{
${ }^{80}$ Vide matéria "Water reportedly sickened U.S. troops in Iraq" em: http://usatoday30.usatoday.com/news/world/iraq/2008-03-09-water_N.htm

${ }^{81}$ Vide matéria "KBR and Halliburton Can Be Sued For Iraq Toxic Burn Pits, Court Rules" em: http://www.corpwatch.org/article.php?id=15941.

${ }^{82}$ Vide "Cheney/Halliburton Chronology" em:

http://www.halliburtonwatch.org/about_hal/chronology.html
} 
movimentos e pessoas para apresentarem sua versão da história é o que modera o impacto de alguma versão específica advinda de determinada fonte, o que também dilui a importância de muita inteligência ser terceirizada e privatizada" (Leander, 2006, p. 23 ).

A relevância do discurso humanitário no âmbito da proteção advinda de EMSPs reside na política especialmente notável não apenas de resposta a um contexto de perigo, mas na produção do medo. Em entrevista, o presidente do Comitê de Segurança e Proteção de Cape Town de 2003, Mululeki George, afirmou que "o setor privado é parasitário da continuação do crime e só pode fazer lucro, se o crime - ou, no mínimo, - o medo do crime continuar" (Abrahamsen \& Williams, 2006, p. 41). Como já discutido, a informação que pode levantar medo na população de um país pode ser superestimada se o controle dela estiver nas mãos do mercado da (in)segurança. Neste caso temos uma política de proteção como uma política de medo. Como aponta o CASE Collective (2006), esta questão é um aspecto que tem implicações para a expansão da segurança a outros campos que manifestam as tendências de privatização. Eles apontam a preocupação de que "a opção pela segurança máxima possa validar-se a posteriori ao fomentar um sentimento de insegurança" (p. 464).

Ao analisar o trabalho de empresas privadas militares e empresas de segurança na África do Sul, Rita Abrahamsen \& Michael Williams (2006) apontam outra consequência a respeito do poder simbólico dos provedores de segurança privada. Eles observam que em uma cultura generalizada de medo criase um hiato de insegurança na estrutura de governança da segurança uma vez que a camada rica da população é a que pode se dar ao luxo de ter a proteção das EMSPs.

No Afeganistão, por exemplo, cidadãos de Cabul relataram a insatisfação que os afegãos sentem ao ver que as EMSPs são basicamente um recurso dos estrangeiros ou dos membros mais ricos daquela sociedade. Como informado pelo Focus Group discussion de 29 de março de 2007: “(...) a participant raised the point that PSCs were sending a strong message that security is not a public good, but a commodity of foreigners and wealthy Afghans (Swisspeace, 2007, p. 31-32).

Com efeito, as atividades das EMSPs em diferentes países podem isolar o espaço da criminalidade "de fora" e ameaçar, de certo modo, a legitimidade social do Estado em sua capacidade de garantir a segurança como um direito acessível a 
todos. Além disso, é importante observar a possibilidade de formação de certas políticas de categorização implicadas na proteção de apenas alguns grupos de indivíduos contra o " grupo perigoso de fora”. Em outras palavras, é possível que uma minoria que possa custear o contrato das EMSPs seja passível de criar um sentido de cidadania apenas entre as pessoas e os territórios habitados pelos seus iguais econômicos, sociais e raciais.

A reprodução do de fora como lugar inseguro também é problemático do ponto de vista da escalada da categorização de grupos perfilados (do inglês profiled groups), isto é, grupos que foram enquadrados no perfil de "risco" e que fazem parte dessas áreas, já que muitos dos lugares onde não existe nem a presença de segurança pública nem privada geralmente apresentam maiores índices de criminalidade.

Como o enquadramento de perfis tem se tornando tão comum quanto a prática da vigilância no dia a dia de algumas EMSPs, não seria improvável que comecem a fazer uso de medidas atuariais e a criar estatísticas com base em traços ou características de grupos. Em sociedades estratificadas existem receios quanto à possibilidade que isto resulte em supervisões ou encarceramentos desproporcionais para certos "perfis sociais" e, além disso, tal método pode contribuir para uma percepção geral exagerada na imaginação pública e entre os oficiais de coerção da lei em relação à criminalidade do grupo perfilado (Harcourt, 2006, p.33). No caso da África do Sul, como apontam Abrahamsen \& Williams (2006), “os significados compartilhados em torno da segurança estão profundamente politizados, pois eles repercutem com as injustiças do passado, as desigualdades do presente e as visões controvertidas de um futuro incerto".

A privatização dos serviços de segurança ou militares não é, portanto, um elemento novo dos últimos tempos e as formas atuais de violência encontradas nas práticas das empresas militares privadas são muitas vezes referidas como sendo parte de uma dinâmica histórica mais ampla da guerra, da violência e da economia política (Mabee, 2009). No entanto, há que se trazer à tona como grandes parcelas das empresas privadas militares e de segurança desenvolvem flexibilidade suficiente para trabalharem diferentes categorias de serviços que são formas muito diferentes do escopo de ação encontradas em suas práticas antes da década de 1990. Pode-se, portanto, destacar que as atividades relacionadas ao desenvolvimento e ajuda humanitária são geridos de acordo com concepções 
particulares de proteção e prevenção. As EMSPs trabalham, portanto, com narrativas que levam em consideração a melhoria de sua posição do mercado e como podem se beneficiar financeiramente no longo prazo e, como já analisado, o envolvimento EMSPs com assuntos humanitários tem sido considerado um caminho que no campo discursivo humanitário dá condições para a legitimidade do setor de segurança comercial dentro deste. 


\section{Conclusão}

\subsection{O significante vazio do humanitarismo}

Ao longo da dissertação, foram expostos distintos processos de formações discursivas. Alguns foram resultados mais evidentes de processos históricos longos, outros foram resultados de oportunidades mais pontuais como a questão militar, econômica, ética e de política externa, e outros foram parte de um conjunto de desenvolvimentos discursivos advindos da área da segurança e das práticas emergenciais.

Como exposto ao longo dos capítulos, ao findar da Guerra Fria, o contexto normativo para as questões de guerra e de paz viria a passar por muitas reformulações políticas e novas narrativas viriam constituir o quadro interpretativo para temas que envolviam soberania, desenvolvimento e o imperativo humanitário. A maior atenção aos problemas internos dos países fragilizados por conflitos civis e as consequentes tragédias que lhes são subsequentes se mostraram como situações que justificariam uma nova reformulação para as condições em que se deve fornecer ajuda humanitária. Seja pela maior visibilidade midiática, seja pela maior capacidade tecnológica de observação das condições domésticas de modo simultâneo no planeta, o fato era que os relatórios produzidos pelos escritórios das agências independentes ou afiliadas às Nações Unidas aumentavam em número e riqueza de detalhes. A indicação estatística e a divulgação dos pormenores de situações que desafiam a consciência humana iriam apelar para discursos tanto de cunho moral deontológico quanto pragmático. $\mathrm{O}$ recurso a narrativas como $\mathrm{a}$ da responsabilidade da comunidade internacional perante as tragédias de um lugar distante e da emergência de análises profiláticas para países em condição de vulnerabilidade organizariam as demadas pela Responsabilidade de Proteger e pela Segurança Humana dentro do espaço discursivo do sistema da ajuda humanitária.

A expansão concomitante do discurso liberal para paz e dos projetos democratizantes para Estados falidos proporcionou um aumento das demandas 
por participação de mais atores do setor privado e por maior capacidade no cumprimento de tarefas em ambientes considerados de risco extremo, momento que também marcaria a área militar privada no que viria a se tornar um processo de agenciamento das EMSPs no campo humanitário.

Havia nesse contexo uma abordagem que visava ser coerente com a visão de uma agenda de desenvolvimento universal, e a luta contra a pobreza, por exemplo, dependeria de políticas destinadas a prevenir conflitos através da reconstrução de países considerados frágeis, e que a patir dos anos 2000 também seria parte de medidas anti-terror visando-se a melhoria da segurança dentro de países desenvolvidos como EUA e Reino Unido.

A paz, o desenvolvimento e os direitos humanos começavam então a ser vistos como interligados e se reforçavam mutuamente. A segurança humana enquanto novo referente para segurança global, se tornava o guarda-chuva destes elementos e estava cada vez mais relacionada à "responsabilidade de proteger", de abordagem semelhante. Enquanto um conceito multidimensional, a segurança humana abrangeria uma ampla gama de componentes fazendo deste significante um ponto nodal para uma série de discursos interligados, a saber: segurança econômica (liberdade de pobreza), segurança alimentar (acesso aos alimentos), segurança da saúde (acesso aos cuidados de saúde e proteção contra doenças), segurança individual (proteção física contra a tortura, guerra, ataques criminosos, violência doméstica), segurança política (direitos civis e políticos, a liberdade da opressão política), segurança ambiental (proteção contra os perigos da poluição ambiental) e a segurança social (sobrevivência das culturas e tradições).

Este conjunto de narrativas se traduziria em práticas por meio de operações multibilionárias em diferentes continentes e as EMSPs passariam da categoria de guardas de pessoas e coisas para provedores de proteção no sentido mais amplo do termo. A flexibilidade e o alargamento das atividades das EMSPs em situações de emergência e não-emergência não apenas foi parte do quadro da propagação de narrativas deste contexto, mas se encaixariam em projetos multidisciplinares financiados por governos e, inclusive, pelas Nações Unidas. A intercessão das práticas humanitárias, de segurança e de desenvolvimento ocorreu e ainda ocorre utilizando-se o vocabulário da proteção e da prevenção, o que legitima muitas contratações de EMSPs principalmente em programas e operações em territórios considerados "frágeis". 
Os prestadores de segurança privada formam, portanto, uma posição de sujeito já estabelecida no campo humanitário e seus discursos apresentam sua posição como parte constitutiva e necessária da proteção de pessoas, materiais, bens e recursos dado seu alto nível de especialização. A problemática da relação entre militarismo e humanitarismo se aprofunda à medida que se criam dependências estruturais entre as abordagens orientadas ao mercado e as abordagens humanitárias, e também levanta questões sobre o seu estabelecimento potencial como atores legítimos do sistema da ajuda e alívio. As consequências potencialmente negativas são expostas por críticas que mostram como estas agências de segurança igualmente modulam o significado da proteção e da prevenção de acordo com uma visão diretamente relacionada com o cálculo de custo-benefício. Através de sua capacidade de transformar o vocabulário e as práticas das situações de emergência, as EMSPs acabam por deter o poder de definir as ameaças e decidir como lidar com elas.

Em parceiria com organizações internacionais e outras instituições do setor privado, as EMSPs também contribuiriam para borrar as fronteiras que os separavam da visão tradicional de segurança, bem como a fronteira que os separavam do universo humanitário. Ressignificava-se assim a neutralidade, narrativa historicamente apreciada por organizações humanitárias e de direitos humanos. Enquanto que muitas agências igualmente abraçavam o paradigma da segurança humana, frequentemente apareceriam críticas associando os chamados "novos humanitários" à ideologia expansionista de alguns países ocidentais. Ataques aos atores humanitários seriam mais corriqueiros, uma vez que, para os locais, não havia grande diferença se comparados às forças de ocupação ${ }^{83}$. A ideia de risco e a necessidade das EMSPs, portanto, passou a se retroalimentar.

Além dos dilemas de segunça criados com sua presença de modo massivo, haviam críticas quanto à consequente dependência que seria provocada com os numerosos contratos com as EMSP já que quando uma organização confia a gestão da sua segurança a um profissional externo, isso pode potencialmente levar a uma diminuição de seu próprio expertise na questão e, consequentemente,

\footnotetext{
${ }^{83}$ Guardas de segurança privada pelo fato de não estarem em roupas civis, ou não usarem identificação em seus veículos acabaram por dificultar a separação entre os agentes humanitários que trabalham no país e as forças de segurança. No Afeganistão, por exemplo, casos como estes retratam o problema que as EMSPs geram ao passarem uma mensagem para a população local de que a segurança não é um bem público e que está apenas disponível para os estrangeiros ou afegãos ricos (Del Prado, 2008, p. 20)
} 
aumentar sua dependência em relação a atores externos (Singer, 2003, p. 78). A EMSPs, deste modo, estabeleciam seu poder de agência no campo humanitário devido às oportunidades que este campo lhes outorgava.

Deste modo, as possibilidades de agenciamento surgiram e ainda surgem no campo geral da discursividade humanitária devido às características específicas que possui enquanto um espaço de articulações de distintas naturezas. Mas como demonstrado ao longo dos capítulos, a existência do campo de per si é dependente de pelo menos três condições: da heterogeneidade discursiva por meio da qual se fazem as articulações políticas, dos deslocamentos das fronteiras internas (por meio de significantes flutuantes) e das relações equivalenciais estabelecidas por meio de significantes vazios com pretensões hegemônicas.

Como foi observado, a heterogeneidade do campo advém dos discursos de distintos agentes, tais como ONGs, organizações governamentais, organizações internacionais, o setor privado, militares, acadêmicos, humanitários tradicionais, novos humanitários e empresas de segurança privada; os deslocamentos das fronteiras internas ocorre por meio das articulações discursivas que no caso do campo humanitário do pós-Guerra Fria se deu pela divisão entre as agências humanitárias que apoiam práticas mais intervencionistas, pela lógica consequencialista, das tradicionalistas que, pela lógica deontológica, não apoiam por questões de princípios. Ademais, percebeu-se como o jogo discursivo a partir dos anos 1990 permitiu que os discursos da segurança humana e dos direitos humanos fossem significantes privilegiados em distintas camadas decisórias. Mesmo com agendas diversas, atores como as EMSPs se tornariam agentes no campo humanitário por meio de sua capacidade em prover segurança e atividades multidimensionais, práticas estas que os aproximam do discurso dos novos humánitarios, complexificando ainda mais o significando do humanitarismo no mundo contemporâneo.

A segurança humana enquanto ponto nodal, contudo, adquiriu um papel relevante como elemento de conexão de demandas diferenciais, e sua relação com outros pontos nodais ou laços equivalenciais como o desenvolvimento e os direitos humanos viria compor um movimento articulatório que constituiu os antagonismos mais expressivos desse campo: o humanitarismo tradicional, o novo humanitarismo e o humanitarismo militar privado. 
A indústria militar privada e seu alto expertise técnico e tático tem demonstrado uma capacidade prática sem precedentes em operações ao redor do globo e seu interesse nas oportunidades advidas do sistema de ajuda humanitária os tem colocado em uma relação de progressiva equivalência discursiva com a lógica consequencialista dos novos humanitários, de modo que em muitos casos não se saiba a distinção entre os mesmos. Deste modo, identifica-se que as relações equivalenciais do campo humanitário expressam uma política em torno da definição do humanitarismo, uma luta de pretenções hegemônicas que torna o nome humanitário, ou humanitarismo, o significante vazio mor do campo discursivo que engloba as operações emergenciais, as operações de paz e as missões de ajuda e alívio internacionais no mundo contemporâneo.

As possibilidades aparentemente ilimitadas de combinação na prática discursiva são, portanto, limitadas e constrangidas por lutas de poder. As fronteiras das ordens discursivas são espaços sociais de disputa e conflito e de onde pode emergir uma visão dominante que vai lutar para manter sua hegemonia na estrutura discursiva, que, no caso do humanitarismo, podemos vislumbrar nos desencadeamentos em relação à evolução das relações de poder entre os atores nesse campo.

O humanitário emerge do antagonismo do campo discursivo que carrega seu nome como um significante vazio, porque expressa uma totalidade de algo que lhe é ausente. A falta constitutiva desse nome se expressa por sua constante necessidade de ressignificação e isso faz dele um significante hegemônico na política internacional contemporânea da qual somente um processo equivalencial contra-hegemônico seria capaz de dissolvê-lo. Ele é igualmente a expressão de uma crise quanto aos limites da agência mediante práticas humanas indesejadas de um outro distante. Como menciona Laclau \& Mouffe (1987):

"Hegemonía" hará alusión a una totalidad ausente y a los diversos intentos de recomposición y rearticulación que, superando esta ausencia originaria, permitieran dar un sentido a las luchas y dotar a las fuerzas históricas de una positividad plena. Los contextos de aparición del concepto serán los contextos de una falla (en el sentido geológico), de una grieta que era necesario colmar, de una contingencia que era necesario superar. La "hegemonía" no será el despliegue majestuoso de una identidad, sino la respuesta a una crisis" (p. 7). 
Mas como a cadeia de significantes do campo geral da discursividadade humanitária tem se mantido? Esta cadeia discursiva se mantém pela sua capacidade de manter os significantes privilegiados de modo co-dependente. O campo tem se alimentado retroativamente de práticas que produzem uma dependência virtual de conceitos como seguranca humana e direitos humanos. A prática humanitária que um dia já pôde ter sido considerada como impensável fora da norma civilizatória é atualmente um espaço de múltiplas governanças. Os atores em posição de antagonismo nesse campo vão lutar para não perderem sua razão de ser, mas as narrativas hegemônicas prosperam à medida que os agentes se convencem de que não existe paz e estabilidade que se origine de outra fonte que não do humanitarismo contemporâneo. A relação entre as fronteiras discursivas do campo humanitário e os discursos mais privilegiados da contemporaneidade podem ser observados na figura 05 . Na imagem, as expansões discursivas não representam necessariamente o impacto ou tamanho real das fronteiras internas e externas do campo, mas pode ser considerada uma expressão do que de mais próximo conseguimos vislumbrar do campo neste momento.

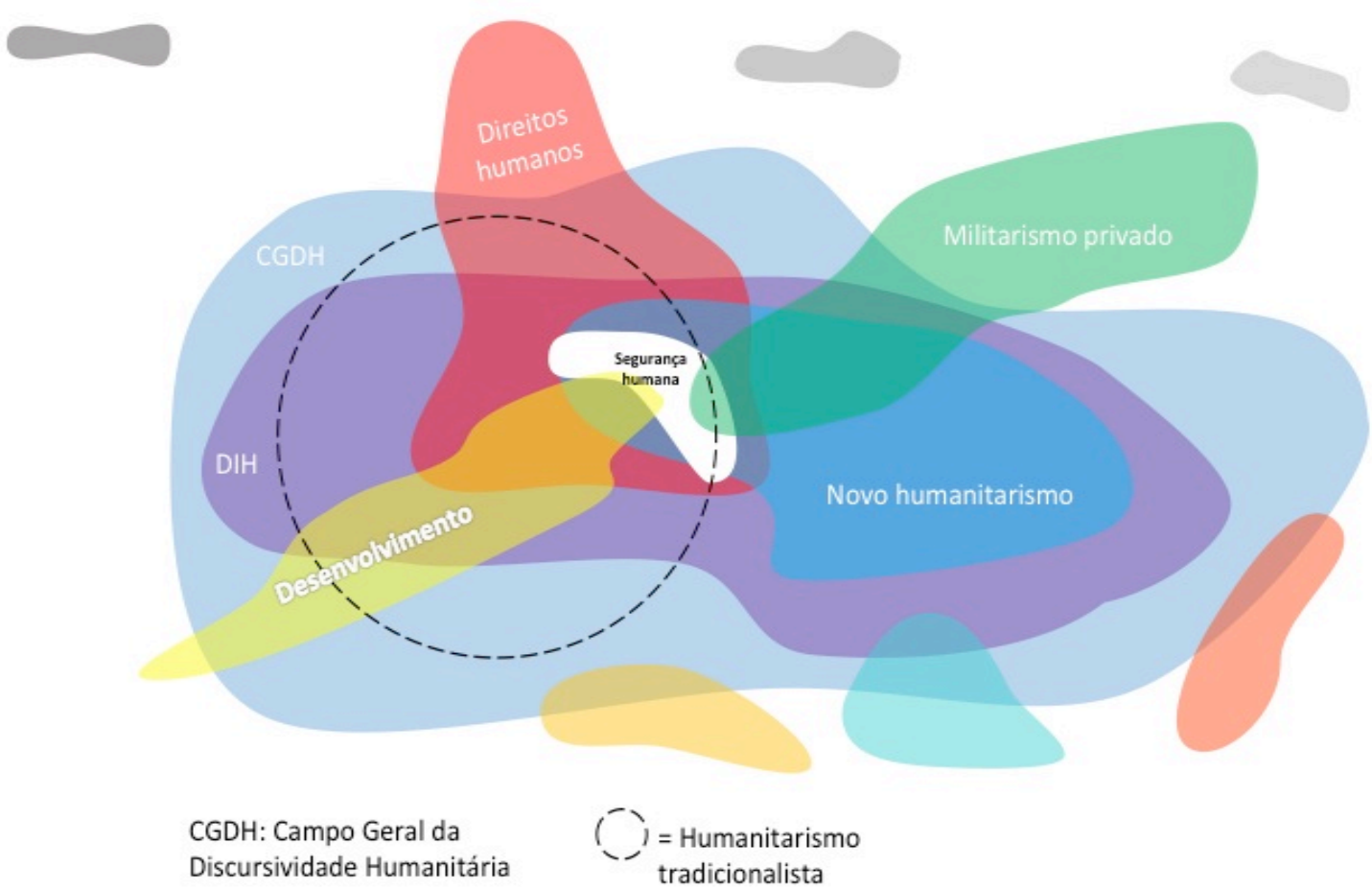

Figura 05: O campo geral da discursividade humanitária 
O campo geral da discursividade humanitária demonstra suas fraturas internas de modo distinto se comparado com à configuração do século anterior. Os agentes que produzem a atividade humanitária constituem-na como uma norma sem a qual a frágil estabilidade do mundo contemporâneo dos estados falidos pareça impensável. O jogo discursivo segue seu curso, no entanto, sempre com possibilidade de uma nova ruptura ainda que atualmente pareça inconcebível o desvencilhamento destes conceitos. Entretanto, o campo humanitário é formado por agentes cujas identidades não são dadas positivamente e por práticas que estão sempre sofrendo interpelações. Assim, a configuração hegemônica do campo geral da discursividade humanitária nunca vai apresentar uma homogeneidade de atores plenamente satisfeitos, tampouco uma heterogeneidade que configure uma cadeia de equivalência totalmente bem-sucedida. Como observam Laclau \& Mouffe (1987):

(...) [Si] negatividad y objetividad solo coexisten a través de su subversión recíproca, esto significa que ni las condiciones de una equivalencia total ni las de una objetividad diferencial total, son nunca plenamente logradas. (...) Pero así como la lógica de la diferencia no consigue nunca constituir un espacio plenamente suturado, tampoco lo logra la lógica de la equivalencia. La disolución del carácter diferencial de las posiciones del agente social a través de la lógica equivalencial, no es nunca completa. Si la sociedad no es totalmente posible, tampoco es totalmente imposible (Laclau \& Mouffe, 1987, p. 150).

Deste modo, ainda que as EMSPs dissolvam uma parte de sua condição diferencial, por exemplo - o discurso mercenário, para entrar em uma lógica de equivalência com os novos humanitários, isso não muda a outra parte diferencial que lhes constitui, isto é, sua orientação a lucros; pois, do contrário, seria uma instituição esquizofrênica, composta por duas lógicas internas opostas, uma voltada ao capital e outra voltada à filantropia, algo que mesmo a sua condição sobredeterminada não daria conta de fazer subsistir; produziria uma grande ruptura interna.

Qual seria, pois, a melhor representação genérica para um espaço tão passível de contingências como o campo geral da discursividade humanitária? A 
resposta está da capacidade relativa que os agentes que lhes constituem têm para produzir antagonismos. Como visto ao longo dos capítulos, há um conjunto bastante heterodoxo de conceitos permeando o campo, mas quando nos referimos a ele como um lugar de divergência de agendas ou um espaço de atores contraditórios demonstramos suas formações antagônicas e, não existe antagonismo sem política e, por consequência, sem formação de cadeias de equivalência. Não há como se propor um modelo geral de campo, pois isto incorreria numa pretensão de positivadade deste campo. Certamente que de modo virtual, pode-se até encontrar nos discursos de diferentes humanitários uma ideia de positividade quando afirmam que as imperfeições do sistema de ajuda humanitária estão "encurtando o espaço humanitário" ou desafiando sua "neutralidade". Porém, já sabemos neste ponto da pesquisa como as narrativas são trabalhadas para legitimar as práticas.

De outro modo, se pensarmos hipoteticamente na possibilidade do campo humánitario ser neutro, imparcial e independente, estaríamos retratando-o como plenamente constituído de uma lógica equivalencial, uma vez que encontraríamos no sistema de ajuda humanitária uma espécie de consenso sobre como estes princípios devem ser respeitados. O espaço humanitário no sentido mais tradicional do termo, seria, de fato, um lugar apolítico. Entretanto, isso não corresponde com a realidade social segundo a abordagem teórico-metodológica aqui proposta. Uma vez que a nem a lógica diferencial nem a equivalencial podem ser totalmente completas, o campo geral da discursividade humanitária será sempre um espaço para política.

Até aqui, vislumbramos, portanto, uma parte significativa das condições de existência das EMSPs no campo humanitário e, consequentemente, a pesquisa ofereceu um quadro analítico que permite a compreensão da emergência de outros atores que não estes. Contudo, sempre haverá perguntas a serem respondidas e que merecem uma investigação mais aprofundada e que não foram exploradas como, por exemplo, quais são os demais pontos nodais que unificam os discursos do setor privado que não comulgam dos interesses de política externa dos Estados ou do discurso da Responsabilidade de Proteger sob o guarda-chuva da segurança humana. Há que se explorar as equivalências que porventura estejam em 
formação advindas de organizações, ativistas, neopacifistas ${ }^{84}$ ou talvez de países menos poderosos na política mundial ${ }^{85}$ e que, apesar de não conseguirem formar uma posição antagônica no campo humanitário contemporâneo, merecem ter seus discursos identificados na condição de significantes flutuantes.

Neste fim, o desdobramento particularmente relevante a partir da pesquisa é mostrar que as possibilidades discursivas são passíveis ou não de reconfiguração dependendo das demandas diferenciais, das equivalencies do campo humanitário e do poder dos sujeitos que compõem este espaço. $\mathrm{O}$ manejo do discurso humanitário no caso das EMSPs contribui para comprometer o status do discurso construído em torno de princípios deontológicos que, apesar de construtos, não necessitam perder sua validade histórica. E a configuração discursiva atual já repercute sobre a vigilância, sobre as liberdades individuais e coletivas em outros campos discursivos que não o humanitário. A ressignificação da ajuda humanitária permitiu, portanto, a mudança das dinâmicas e dos dilemas gerados pelo processo hegemônico da formação de significantes vazios no campo geral da discursividade humanitária, bem como de seus desdobramentos éticos e políticos. O arcabouço teórico escolhido explorou assim o campo humanitário de um modo que esclaresce as diferenças entre as formas discursivas de um campo, algo que se sugere como um relevante meio para se decifrar outras arquiteturas presentes nas fronteiras internas do que se compreende como as "relações internacionais".

\footnotetext{
${ }^{84}$ Algumas destas articulações já foram identificadas como advindos de grupos bem adversos, como anti-imperialistas, realpolitikers e neopacifitas, mas que defendem em comum o fim da arquitetura humanitária contemporânea. Estes posicionamentos podem ser encontrados em Macrae (1998).

${ }^{85}$ Embora não representem necessariamente uma condição de "menos poderosos" na política mundial, os países membros do BRICS, por exemplo, têm exposto uma posição crítica à lógica do R2P das intervenções humanitárias ao não votarem a favor da intervenção na Líbia e criticarem as resoluções na Síria. Vide: http://www.foreignpolicyjournal.com/2011/10/12/the-end-of-theresponsibility-to-protect/
} 


\section{Referências Bibliográficas}

ABRAHAMSEN, Rita; WILLIAMS, Michael. Privatisation, Globalisation, and the Politics of Protection in South Africa. In: HUYSMANS, Jef; DOBSON, Andrew; PROKHOVNIK, Raia (Eds). Politics of Protection: Sites of insecurity and political agency. New York: Routledge, 2006. p. 34-47.

Access to the Danger Zone. Direção: Peter Casaer, Eddie Gregoor. Produção: Eddie Gregoor. Bélgica, Somália, Quênia, Congo, Afeganistão, 2012. 1 DVD (70 $\min )$.

ADRP 3-07. Army Doctrine Reference Publication, 31 Aug. 2012. Disponível em: <https://armypubs.us.army.mil/doctrine/index.html>. Acesso em: $10 \mathrm{Jul}$. 2014.

AGAMBEN, Giorgio. Homo Sacer: o poder soberano e a vida nua I, trad. Henrique Burigo, 2.ed. Belo Horizonte: Ed. UFMG, 2002.

ANSI/ASIS PSC.1 2012. Management System for Quality of Private Security Company Operations - Requirements With Guidance. American National Standard, ASIS International, Mar. 2012.

ARRIGHI, Giovanni. 1994. The Long Twentieth Century: money, power, and the origins of our times. New York: Verso.

AVANT, Deborah. From Mercenary to Citizen Armies: explaining change in the practice of war. International Organization, v. 54, n. 1, winter, 2000.

Deborah. Privatizing Military Training. Foreign Policy in Focus, v. 7, n. 6, may 2002 .

Deborah. The Emerging Market for Private Military Services and the Problems of Regulation. In: CHESTERMAN, Simon; LEHNARDT, Chia. From Mercenaries to Market: the rise and regulation of Private Military Companies. New York: Oxford University Press, 2007a. p. 181-195.

Deborah. NGOs, Corporations, and Security Transformation in Africa. International Relations, v. 29, n. 2, $2007 \mathrm{~b}$.

BAKER, Deane-Peter; PATTISON, James [Draft]. The Principled Case for Employing Private Military and Security Companies in Humanitarian Interventions and Peacekeeping Operations. Association of Legal and Social Philosophy's Annual Conference, University of Edinburg, jul. 2009. 
BARNETT, Michael; WEISS, Thomas (eds). Humanitarianism in Question: politics, power, ethics. Ithaca: Cornell University Press, 2008.

BARNETT, Michael. Humanitarianism Transformed. Perspectives on Politics, v. 3, n. 4, 2005.

. Michael. The Empire of Humanity: A history of humanitarianism. Ithaca: Cornell University Press, 2011.

BERNDTSSON, Joakim. Security Professionals for Hire: exploring the many faces of private security expertise. Millennium: Journal of International Studies. v. 40, n. 2, p. 303-320, 2012.

BRASSARD-BOUDREAU, Cynthia; HUBERT, Don. Shrinking Humanitarian Space? Trends and prospects on and future perspectives. The Journal of Humanitarian Assistance, nov. 2011.

BREKALO, Andrea. Enquiry into the Private Security and Military Companies' Identities: shifting the paradigm in conseptualising security, 2012. 65f. Master's Dissertation - Central European University, Hungary, Budapest, 2012.

BROOKS, Doug. Response to Jeremy Scahill on Engelhardt's blog, apr. 2007. Disponível em: $<$ http://www.academia.edu/5889479/Response_to_Jeremy_Scahill_on_Engelhard ts_blog>. Acesso em: 13 fev. 2014.

Doug. Publicação eletrônica [mensagem pessoal]. Entrevista concedida

à Kárida Mateus de Souza, Providence, RI. Recebida por $<$ kmateus@hotmail.com>em 05 fev. 2014.

CAMERON, Lindsey. Private Military Companies: their status under International Humanitarian Law and its impact on their regulation. International Review of the Red Cross. v. 88, n. 863, sep. 2006.

CALHOUN, Craig. The Imperative to Reduce Suffering: charity, progress, and emergencies in the field of humanitarian action. In: BARNETT, Michael; WEISS, Thomas G. (Eds.). Humanitarianism in Question: politics, power, ethics. Ithaca, NY: Cornell University Press, 2008. p. 73-97.

CARE. AID: Mean Times for Humanitarian Relief. University of Pennsylvania, African Studies Center, 26 jan. 1999. Disponível em: $<$ http://www.africa.upenn.edu/Hornet/irin_1261999.html $>$. Acesso em: 03 set. 2014.

CASE Collective. Critical Approaches to Security in Europe: a networked manifesto. Security Dialogue, v. 37, n. 4, dec. 2006. 
CHANDLER, David. From Kosovo to Kabul: human rights and international intervention, 2.ed. London: Pluto Press, 2006.

CHR. Commission on Human Rights Report [E/CN.4/2005/23], 2005. Disponível em: <http://www.unwg.rapn.ru/en/1.htm>. Acesso em: 29 out. 2012.

CICV. O Que é o Direito Internacional Humanitário? 31 jan. 1998, Ficha Técnica. Disponível em: $<$ http://www.icrc.org/por/resources/documents/misc/5tndf7.htm $>$. Acesso em: 24 jun, 2014.

COCKAYNE, James; MEARS, Emily S. Private Military and Security Companies: a framework for regulation. International Peace Institute, mar. 2009.

- James. Commercial Security in Humanitarian and Post-Conflict Settings: an exploratory study. International Peace Academy, 2006b.

. James. Commercial Security in the Humanitarian Space. International Peace Academy, 2006a.

CURRIER, Nuchhi. Strengthening Staff Security: priorities and challengesprotecting the protectors. UN Chronicle, v. 40, n. 2, 2003.

DAC. Development Assistance Committee. Statistics Department, IMF and the Development Co-operation Directorate, OECD, Oct. 1998, 12p. Disponível em $<$ https://www.imf.org/external/bopage/pdf/98-1-4.pdf>. Acesso em: 13 fev. 2014.

DEBRIX, François. Re-envisioning Peacekeeping: the United Nations and the mobilization of ideology. Minneapolis, London: University of Minnesota Press, 1999.

DEL PRADO, José L. Gómez. Private Military and Security Companies and Challenges to the UN Working Group on the Use of Mercenaries. Conference on Private Military Contractors in Latin America, feb. 2008. Disponível em: $<$ http://www.havenscenter.org/privatemilitaryconference2008 $>$. Acesso em: 4 set. 2014.

DOUZINAS, Costas. The Many Faces of Humanitarianism. Parrhesia, n. 2, p. 01-28, 2007.

DUFFIELD, Mark. Global Governance and the New Wars: the merging of development and security. London and New York: Zed Books, 2001.

. Mark. Social Reconstruction and the Radicalization of Development: aid as a relation of global liberal governance. Development and Change, n. 33, p. 1049-72, 2002.

DUNANT, Henry. A Memory of Solferino. ICRC publication, ref. 0361, 1986. 
DUNNING, Rebecca. Heroes or Mercenaries: Blackwater, Private Security Companies, and the U.S. military institutions in crisis. The Kenan Institute for Ethics, Duke University, 2010.

ESTEVES. Paulo. A Convergência entre Práticas Humanitárias e Segurança Internacional. Belo Horizonte: Del Rey, 2010a.

Paulo. Peace Operations and the Government of Humanitarian Spaces. International Peacekeeping, v. 7, n. 5, p. 613-662, nov. $2010 \mathrm{~b}$.

. Paulo. Unfolding the International at Late Modernity: humanitarian space and therapeutic politics, NUPI Working Paper, n. 746, p. 1-30, 2008.

FEARON, James. The Rise of Emergency Relief Aid. In: BARNETT and WEISS (eds). Humanitarianism in Question: Politics, Power, Ethics. Ithaca: Cornell University Press, 2008, p. 49-52.

FINNEMORE, Martha. Constructing Norms of Humanitarian Intervention. In: KATZENSTEIN, Peter J. (Ed.). The Culture of National Security: norms and identity in world politics, 1996, p. 153-185.

FORSYTHE, David. The Humanitarians: the International Committee of Red Cross. Cambridge: Cambridge University Press, 2005.

FOX, Fiona. Conditioning the Right to Humanitarian Aid? Human rights and the 'new humanitarianism'. In: CHANDLER, David. Rethinking Human Rights: critical approaches to international politics. New York, N.Y: Palgrave Macmillan, 2002. p. 19-37.

GENERAL ORDERS (Francis Lieber Code), No. 100. Adjutant General's Office, abr. 1863, Washington: Government Printing Office, 1898.

GUIDERO, Amanda. Humanitarian, Development, and Private Security Actors in the Field: a security analysis in Somalia. Zeus IFSH, Working Paper 2, dec. 2012.

HAGUE CONVENTION V Respecting the Rights and Duties of Neutral Powers and Persons in Case of War on Land (Hague V) Oct. 28, 1907. The Avalon Project, Yale University.

HANSEN, Lene. Security as Practice: discourse analysis and the Bosnian war. London and New York: Routledge, 2006.

HARCOURT, Bernard. Against Prediction: punishing and policing in an actuarial age. Oxford Jurisprudence Group, University of Chicago press, 9 mar. 2006.

HELLINGER, Daniel. Humanitarian Action, NGOs and the Privatisation of the Military. Webster University, European Interagency Security Forum, 2004. Disponível

em: 
$<$ http://www.eisf.eu/resources/library/hum_action_mil_privatisation.pdf $>$. Acesso em: 10 Fev. 2014.

HERZ, Monica. International Rules on Violence. HASOW, discussion paper 3, mar. 2013. Disponível em: $<$ http://www.hasow.org/uploads/trabalhos/96/doc/1206565660.pdf $>$. Acesso em: 05 set. 2014.

HILHORST, Dorothea; JANSEN, Bram J. Humanitarian Space as Arena: A Perspective on the Everyday Politics of Aid. Development and Change, v. 41, n. 6, p. 1117-1139, nov. 2010.

HPG. Humanitarian Policy Group Report 23. Providing Aid in Insecure Environments: trends in policy and operations. Abby Stoddard, Adele Harmer, Katherine Haver. Overseas Development Institute, 2006.

HPG. Humanitarian Policy Group Report 27. The Use of Private Security Providers and Services in Humanitarian Operations. Overseas Development Institute, 2008.

HUYSMANS, Jef. Agency and the politics of protection Implications for security studies. In: HUYSMANS, Jef; DOBSON, Andrew; PROKHOVNIK, Raia. (Eds). Politics of Protection: Sites of insecurity and political agency. New York: Routledge, 2006. p. 1-18.

ICI. Nigeria: Operation Focus Relief, 2000a. Disponível em: $<$ http://www.icioregon.com/Nigeria4.htm>. Acesso em 03 set. 2014.

ICI. Sudan: Medical Training, 2000b. Disponível em: $<\mathrm{http}$ ://www.icioregon.com/Sudan3.htm>. Acesso em 03 set. 2014.

ICoC SIGNATORY COMPANIES. International Code of Conduct for Private Security Service Providers Signatory Companies, 2013.

ICoC. International Code of Conduct for Private Security Service Providers. Switzerland Confederation, 2012.

ICSS. International Commission on Intervention and State Sovereignty. The Responsibility to Protect. Ottawa: IDRC Research Centre, 2001. Disponível em: $<$ http://responsibilitytoprotect.org/ICISS\%20Report.pdf $>$. Acesso em: 03 Set. 2014.

ISENBERG, David. Private Military Contractors and U.S. Grand Strategy. PRIO: International Peace Research Institute, Oslo. Report 1, 2009. p. 15.

David. Shadow Force: Private Security Contractors in Iraq. London: Praeger Security International, 2009. 
David. What Role for PMC in Today's World?, Huffington Post, 19 nov. 2012. Disponível em: <http://www.huffingtonpost.com/david-isenberg/rolepmc-todays-world_b_2156000.html $>$. Acesso em: 30 jul. 2014.

ISOA. ISOA Code of Conduct, oct. 2011. Disponível em: <http://www.stabilityoperations.org/?page $=$ Code $\&$ hhSearchTerms $=\% 22$ human + and + security $\% 22>$. Acesso em: 03 set. 2014.

JOACHIM, Jutta; SCHNEIKER, Andrea. New Humanitarians? Frame appropriation through Private Military and Security Companies. Millennium: Journal of International Studies, v. 40, n. 2, p. 365-388, 2012.

JØRGENSEN, W. Marianne; PHILLIPS, Louise. Discourse Analysis As Theory and Method Account. London: Sage Publications Ltd, 2002.

KENNEDY, David. The Dark Side of Virtue: reassessing international humanitarianism. Princeton: Princeton University Press, 2004.

KEOHANE, Robert. After Hegemony: cooperation and discord in the world political economy. Princeton, NJ: Princeton University Press, 1984.

KINSEY, Christopher. Corporate Soldiers and International Security: the rise of Private Military Companies. New York: Routledge, 2006.

KRASNER, Stephen D. Causes and Regime Consequences: Regimes as Intervening Variables. International Organization, v. 36, n. 2, p. 185-205, spring, 1982.

LACAN, Jacques. Écrits: a selection. Trad. Alan Sheridan. London: Tavistock Publications, 1977. p. 303.

LACLAU, Ernesto; MOUFFE, Chantal. Hegemonia y Estrategia Socialista: hacia una radicalización de la democracia. Madrid: Siglo XXI, ed. digital (ed. impressa: 1985), 1987.

LACLAU, Ernesto. La Razón Populista. Trad. Soledad Laclau. MexicoArgentina- Brasil- Chile- Colombia- España- Estados Unidos- Guatemala- PerúVenezuela: Fondo de Cultura Económica, 2005.

Ernesto. Os Novos Movimentos Sociais e a Pluralidade do Social. Revista Brasileira de Ciências Sociais, v. 1, n. 2, out. 1986.

LEANDER, Anna. Privatizing the Politics of Protection: military companies and the definition of security concerns. In: HUYSMANS, Jef; DOBSON, Andrew; PROKHOVNIK, Raia. (Eds). Politics of Protection: Sites of insecurity and political agency. New York: Routledge, 2006. p. 19-33. 
Anna. The Market for Force and Public Security: the destabilizing consequences of Private Military Companies. Journal of Peace Research, v. 42, n. 5, p. 605-622, 2005.

Anna. Commercial Security Practices. In: BURGESS, Peter J. (Ed), Handbook of New Security Studies. London and New York: Routledge. 2010. p. 208-216.

LEEBAW, Bronwyn. The Politics of Impartial Activism: humanitarianism and human rights. Perspectives on Politics, v. 5, n. 2, p. 223-23, Jun. 2007.

MABEE, Bryan. Pirates, Privateers and the Political Economy of Private Violence. Global Change. Peace \& Security, v. 21, n. 2, p. 139-152, 2009.

MACFARLANE, S. Neil; KHONG, Yuen F. Human Security and the UN: a critical history. Bloomington: Indiana University Press, 2006.

MENDONÇA, Daniel de. Antagonismo Como Identificação Política. Revista Brasileira de Ciência Política, Brasília, n. 9, dec. 2012. Disponível em: $<$ http://www.scielo.br/scielo.php?script=sci_arttext\&pid=S0103$33522012000300008 \& \operatorname{lng}=$ en\&nrm=iso $>$. Acesso em: 06 jan. 2014.

MILLIKEN, Jennifer. The Study of Discourse in International Relations: a critique of research and methods. European Journal of International Relations, v. 5, n. 2, jun. 1999.

MILLS, Kurt. Neo-Humanitarianism: the role of international humanitarian norms and organizations in contemporary conflict. Global Governance, n. 11, p.161-183, 2005 .

MOUAWAD, Jad. Shell to Pay $\$ 15.5$ Million to Settle Nigerian Case. The New York Times, 9 jun. 2009. Disponível em: $<$ http://www.nytimes.com/2009/06/09/business/global/09shell.html?_r=2\&ref=w orld\&>. Acesso em: 08 jul. 2014.

MSF. Voices From the Field. Afghanistan: health needs will only increase, 21 nov. 2010. Disponível em: $<$ http://www.doctorswithoutborders.org/article/afghanistan-health-needs-willonly-increase $>$. Acesso em: 15 jul. 2014.

MUGGAH, Robert; SAVAGE, Kevin. Urban Violence and Humanitarian Action: engaging the fragile city. Journal of Humanitarian Assistance, jan. 2012.

NDLOVU-GATSHENI, Sabelo J.; DZINESA, Gwinyayi A. 'One Man's Volunteer Is Another Man's Mercenary?' mapping the extent of mercenarism and its impact on human security in Africa. In: GUMEDZE, Sabelo (Ed.). Elimination of Mercenarism in Africa: a need for a new continental approach. ISS Monograph Series, n. 147, jul. 2008. Disponível em: 
$<$ http://psm.du.edu/media/documents/reports_and_stats/think_tanks/iss_gumedze _elimination_of_mercenarism_in_africapdf.pdf $>$. Acesso em: 31 Jul. 2014.

NEUMANN, Iver; SENDING, Ole Jacob. Governing the Global Polity. University of Michigan Press, p. 75-97, 2010.

NEUMANN, Iver. Discourse Analysis. In: KLOTZ, Audie; PRAKASH, Deepa (eds). Qualitative Methods in International Relations: a pluralist guide. New York: Palgrave Macmillan, 2008. p. 61-77.

O'BRIEN, Kevin. Military-Advisory Groups and African Security: privatized peacekeeping. International peacekeeping, n. 3, autumn, 1998.

O'REILLY, Conor. Endurable Disorder or Unsustainable Security? Transnational security consultancy firms in Iraq [Draft]. Centre for Criminology, University of Oxford. Paper presented at WISC Ljubljana, Slovenia, 23-26 jul. 2008.

ONUF, Nicholas. Constructivism: a User's Manual. In: KUBALKOVA, Vendulka; ONUF, Nicholas; KLOWERT, Paul (Eds.). International Relations in a Constructed World. Armonk, NY: M.E. Sharpe, 1998. p. 58-78.

Nicholas. World of Our Making: rules and rule in social theory and international relations. Columbia, SC: University of South Carolina Press, 1989.

ØSTENSEN, Åse Gilje. UN Use of Private Military and Security Companies: Practices and Policies, security sector reform (SSR), paper 3. The Geneva Centre for the Democratic Control of Armed Forces (DCAF), 2011.

POGO. Project on Government Oversight. BOLKOVAC, Kathryn. DynCorp International Inc.: human trafficking in Bosnia-Herzegovina, 2002.

REDFIELD, Peter. The Verge of Crisis: Doctors Without Borders in Uganda. In: FASSIN, Didier; PANDOLFI, Mariella (Eds.). Contemporary States of Emercengy: the politics of military and humanitarian interventions. New York: Zone Books, 2010. p. 173-195.

REUS-SMIT, Christian. The Constitutional Structure of International Society and the Nature of Fundamental Institutions. International Organization, v. 51, n. 4, autumn, p. 555-589, 1997.

Christian. The Moral Purpose of the State: State: social identity and institutional action. Princeton: Princeton University Press, 1999.

ROBERTS, Adam; GUELFF, Richard. Documents on The Laws of War. New York: Oxford University Press, 1989.

ROCK, Joeva. Militarized Humanitarianism in Africa. Foreign Policy in Focus. 14 maio 2014. Disponível em: <http://fpif.org/militarized-humanitarianismafrica>. Acesso em: 02 Jul 2014. 
RODOGNO, Davide. Against Massacre: Humanitarian Interventions in the Ottoman Empire (1815-1914). Princeton: Princeton University Press, 2011.

Davide. Review of Michael Barnett. The Empire of Humanity: A history of humanitarianism. Ithaca: Cornell University Press, 2011. Journal of International Organisation Studies, n.1, 2012.

ROSÉN, Frederik. Commercial Security: conditions of growth. Security Dialogue, v. 39, n. 1, fev. 2008.

RUDOLPH, Terence A. The Securitization of Humanitarian Aid: a case study of the Dadaab refugee camp. 2013. 145 f. Master's dissertation, Dalhousie University. Halifax, Nova Scotia, 2013.

SCAHILL, Jeremy. Blackwater: the rise of the world's most powerful mercenary army. London: Serpent's Tail, 2007.

Jeremy. Dirty Wars: the world is a battlefield. New York: Nation Books, 2013.

SIDA, Lewis. Challenges to Humanitarian Space: A review of humanitarian issues related to the UN integrated mission in Liberia and to the relationship between humanitarian and military actors in Liberia. Monitoring and Steering Group (MSG), Liberia, abr. 2005.

SIEGEL, Marc. 35th Round Table on International Humanitarian Law and Private Military and Security Companies: current issues of International Humanitarian Law, San Remo, p. 1-5, 6-8 Sep. 2012.

SINGER, Peter. Corporate Warriors: the rise of the privatized military industry and its ramifications for international security. International Security, v. 26, n. 3, p. 186-220, winter, 2001.

. Peter. Corporate Warriors: the rise of the privatized military industry. Ithaca: Cornell University Press, 2003.

SMITH, Anna Marie. Laclau and Mouffe: the radical democratic imaginary. London: Routledge, 1998.

SMITH, Barbara. The Dangers of Aid Word. In: DANIELI, Yael (ed.). Sharing the Front Line and the Back Hills - International Protectors and Providers: peacekeepers, humanitarian aid workers and the media in the midst of crisis. Amityville, NY: Baywood Publishing, 2002.

SOUZA, Letícia C. Segurança, Desenvolvimento e Reconstrução de Estados: o caso Libéria (2003-2008), Belo Horizonte, 2010. 172f. Dissertação de Mestrado, Instituto de Relações Internacionais, PUC-Minas. 
SPEARIN, Christopher. Private, Armed and Humanitarian?: States, NGOs, International Private Security Companies and Shifting Humanitarianism. Security Dialogue, n. 39, p. 363-82, 2008.

SWISS FEDERAL COUNCIL REPORT. Report by the Swiss Federal Council on Private Security and Military Companies. Dec. 2005. Disponível em: $<\mathrm{http}$ ://psm.du.edu/media/documents/national_regulations/countries/europe/switz erland/report_swiss_2005_private-security-and-military.pdf $>$. Acesso em: 6 jan. 2014.

SWISSPEACE. Focus Group. Private Security Companies and Local Populations: an exploratory study of Afghanistan and Angola, nov. 2007. Disponível em: $<\mathrm{http}: / /$ psm.du.edu/media/documents/reports_and_stats/think_tanks/swisspeace_p scs_in_angola_and_afghanistan.pdf $>$. Acesso em: 16 jul. 2014.

TERRY, Fiona. Condemned to Repeat?: The paradox of humanitarian action. Ithaca: Cornell University Press, 2002.

THOMPSON, Janice. Mercenaries, pirates, and sovereigns: state-building and extraterritorial violence in early modern Europe. Princeton: Princeton University Press, 1994.

THÜRER, Daniel. Intenational Humanitarian Law: theory, practice, context. Hague: Hague Academy of International Law, 2011. p. 255.

UN. A/68/339. General Assembly. Report on the Use of Mercenaries as a Means of Violating Human Hights and Impeding the Exercise of the Right of Peoples to Self-Determination. Ago, 2013. Disponível em: $<$ http://psm.du.edu/media/documents/international_regulation/united_nations/hu man_rights_council_and_ga/wg_on_mercenaries/resolutions/a-res-68-339.pdf $>$. Acesso em: 30 jun. 2014.

VAN BRABANT, K. Humanitarian Action and Private Security Companies. Humanitarian Exchange Magazine, HPN, n. 20, mar. 2002.

VAUX, Tony et al. Humanitarian Action and Private Security Companies: opening the debate. International Alert, mar. 2002. Disponível em: $<$ http://www.operationspaix.net/DATA/DOCUMENT/5736 v $\sim$ Humanitarian_Ac tion_and_Private_Security_Companies_Opening_the_Debate.pdf $>$. Acesso em: 29 out. 2012.

VESTERGAARD, Anne. Distance and Suffering: humanitarian discourse in the age of mediatization. Copenhagen Business School: PhD Series, dec. 2011.

WALKER, Tom; LAVERTY, Aidan. CIA Aided Kosovo Guerrilla Army. The Sunday Times, London, UK, 12 mar. 2000. 
WARNER, Daniel. The Politics of the Political/Humanitarian Divide. International Review of the Red Cross, n. 833, mar. 1999. Disponível em: $<\mathrm{http}: / /$ www.icrc.org/eng/resources/documents/misc/57jpt3.htm>. Acesso em: 01 set. 2014.

WEBER, Max. Politics as a Vocation. In: DREIJMANIS, John (ed.). Max Weber's Complete Writings on Academic and Political Vocations, 1864-1920. Trans. Gordon C. Wells. New York: Algora Publishing, 2008.

WEISS, Thomas G. Humanitarian Business. Cambridge, UK: Polity Press, 2013.

WENDT, Alexander. Social Theory of International Politics. Cambridge: Cambridge University Press, 1999.

ŽIŽEK, Slavoj. The Sublime Object of Ideology. London: Verso, 1989. 